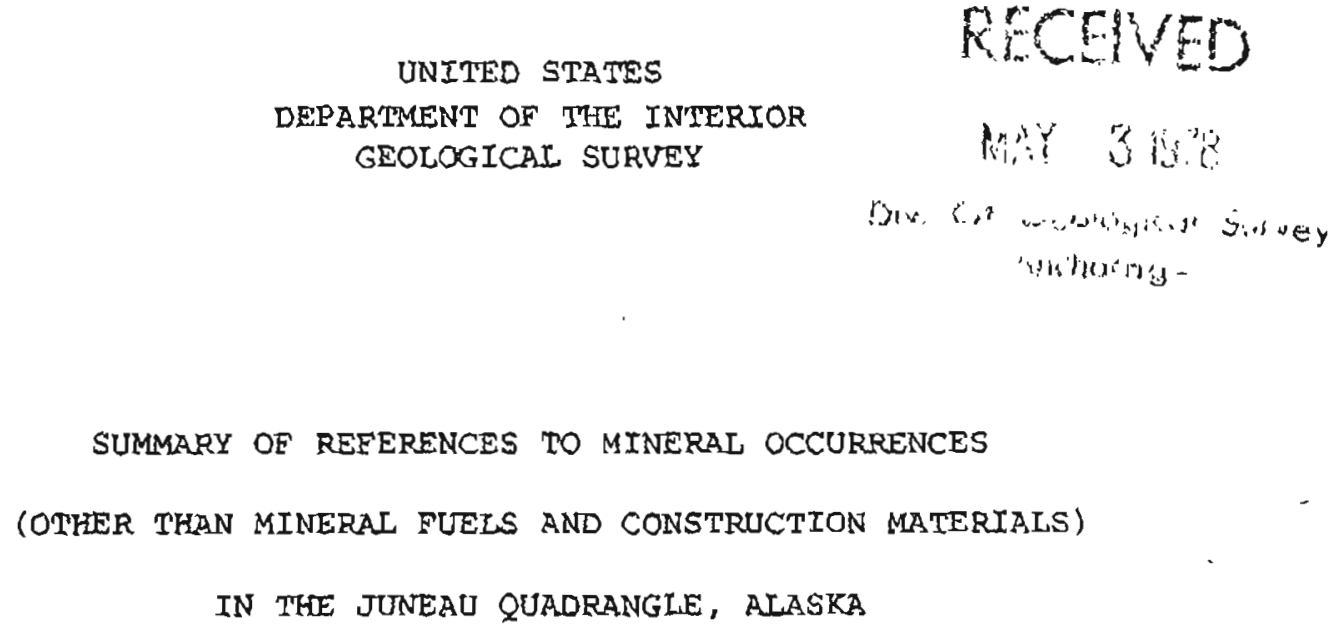

By

Edward H. Colbo
Open-file Roport 78-374
2978

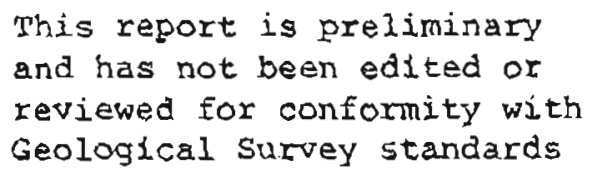


These summaries of references are designed to aid in library research on metallic and nonmetallic lother than mineral fuels and construction materials) mineral occurrences in the Juneau quadrangle, Alaska. All references to reports of the Geological survey, to most reports of the U.S. Buresu of Mines, and to most reports of the State of Alaska Division of Geological and Geophysical surveys and its pxedecessor state and Territorial agencies released before January 1, 1978, are sumarized. One report published in a scientific journal also is included. certain, mainly statistical, reports such as the annual Minerals Yearbook of the U.S. Bureau of Mines and the biennial and annual reports of the state of Alaska Division of Geological and Geophysical Surveys and its predecessor state and Territorial agencies are not included.

This report is divided into three parts: a section made up of summaries of references axranged alphabetically by occurrence neme; a section that lists synonyms for nares in the first section, clairu names, and the names of operators and owners of mines and prospects; and a section that lists, by author, all references sumarized in the first section. 


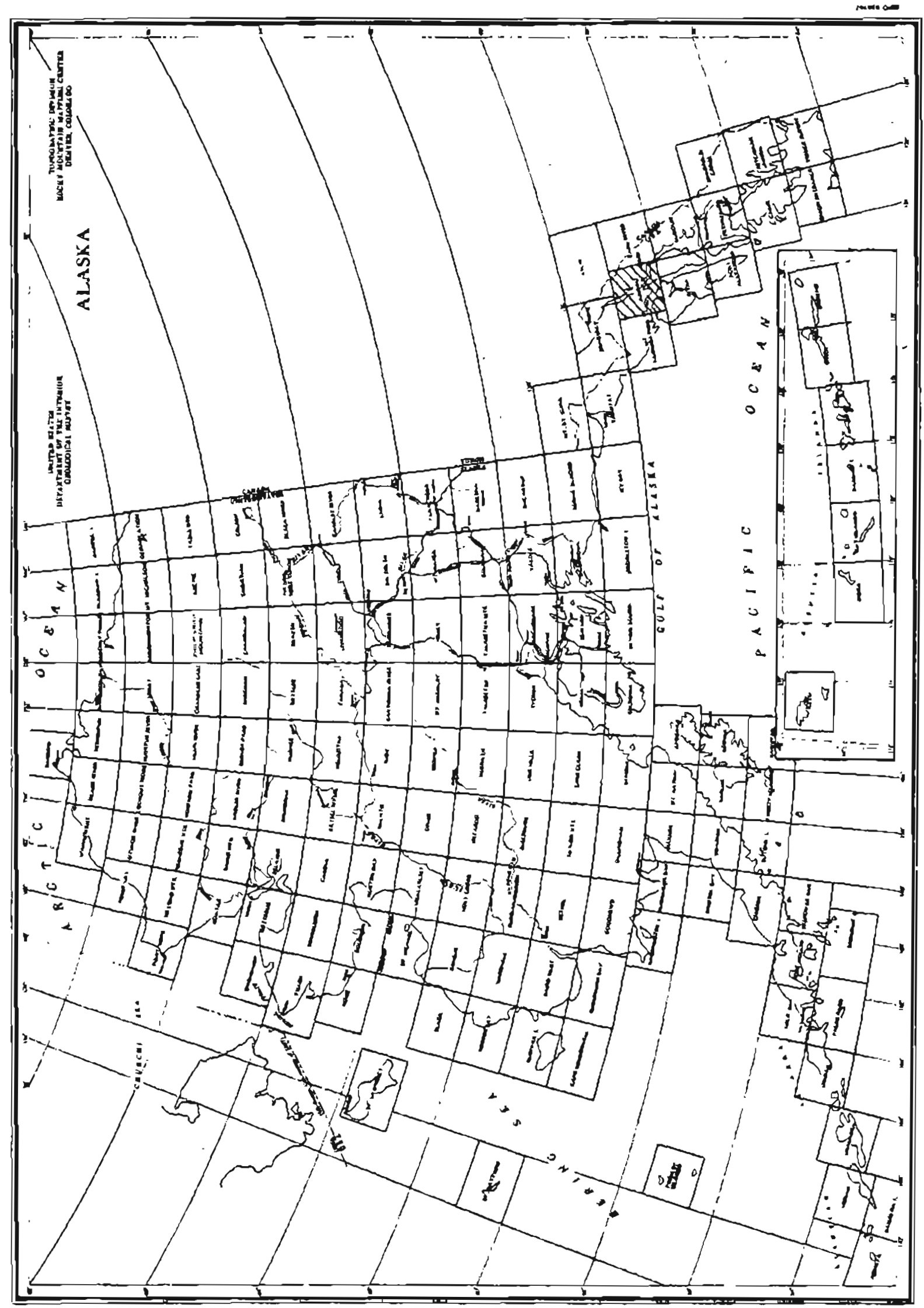

Index Map 


\section{Summeries of Referencs}

For each mineral occurrence there is a page that gives the name of the occurrence; the mineral commodities present (iisted alphabetically for metalilc commodities and then for nommetallic commodities; the mining district (Ransome and Kerns, 1954) in which the occurrence is located; the name of the 1:250,000-scale topographic quadrangle (Jumeau); coordinates (as described by Cobb and Kachadoorian, 1961, p. 3-4); the metallic mineral resources map number (MF-435) and the occurrence number on that map if the occurrence is shown; and the latitude and longitude of the occurrence. These data, presented at the top of the page, are followed by a short, general sumary of the published information on the occurrence. This is followed (continued on additional pages, if necessary) by more detailed sumaries, arranged chronologically, of all references to the occurrence. Material in brackets is interpretive or explanatory and is not in the summarized reference.

Proper names of mines, prospects, and other minexal occurrences are given if such names appear in the reports surmarized. If a deposit does not have such a name, but is near a named geographic feature, the name of that feature is shown in parentheses in lieu of a proper name. If a part of a proper name is not always used in a reference, that part of the name is shown in parentheses. This is most common in company names and in place narues with uinor variations in spelling.

Citations are given in standard bibliographic format with the exception that references to reports and maps in numbered publication series also show, in parentheses, an abbreviation for the report or map series 
and the report or map number. Abbreviations used are:

$\begin{array}{ll}\text { B } & \text { U.S. Geological Survey Bulletin } \\ \text { BMB } & \text { U.S. Bureau of Mines Bulletin } \\ \text { C } & \text { U.S. Geological Survey Circular } \\ \text { GC } & \text { Alaska Division of Geological and Geophysical Surveys } \\ & \text { (and predecessor State agencies) Geochemical Report } \\ \text { GQ } & \text { U.S. Geological Survey Geologic Quadrangle Map } \\ \text { GR } & \text { Alaska Division of Geological and Geophysical Surveys } \\ & \text { (and predecessor State agencies) Geologic Report } \\ \text { I } & \text { U.S. Geological Survey Miscellaneous Geologic Investiga- } \\ & \text { tions Map } \\ \text { IC } & \text { U.S. Bureau of Mines Information Circular } \\ \text { OF } & \text { U.S. Geological Survey Open-file Report (numbers are in- } \\ & \text { Eormal and used only within the Alaskan Geology Branch } \\ \text { P } & \text { of the U.S. Geological Survey) } \\ \text { RI } & \text { U.S. Geological Survey Professional Paper } \\ \text { USBM OF } & \text { U.S. Bureau of Mines Report of Investigations }\end{array}$

Summaries are as I made then while reading the cited reports, I

made no attempt to use complete sentences and did not edit for grammati-

cal consistency, although I have tried to edit out ambiguities.

References cited only in these introductory paragraphs are:

Cobb, E. H., and Kachadoorian, Reuben, 1961, Index of metallic anô nonmetallic mineral deposits of Alaska compiled from published reports of Federal and state agencies through 1959: U.S. Geol. Survey BuI1. $1139,363 \mathrm{p}$.

Ransome, A. L., and Kerns, W. H., 1954, Names and definitions of regions, aistricts, and subdistricts in Alaska (used by the Bureau of Mines in statistical and economic studies covering the mineral industry of the Territory): U.S. Bur. Mines Inf. Circ. 7679, $91 \mathrm{p}$. 


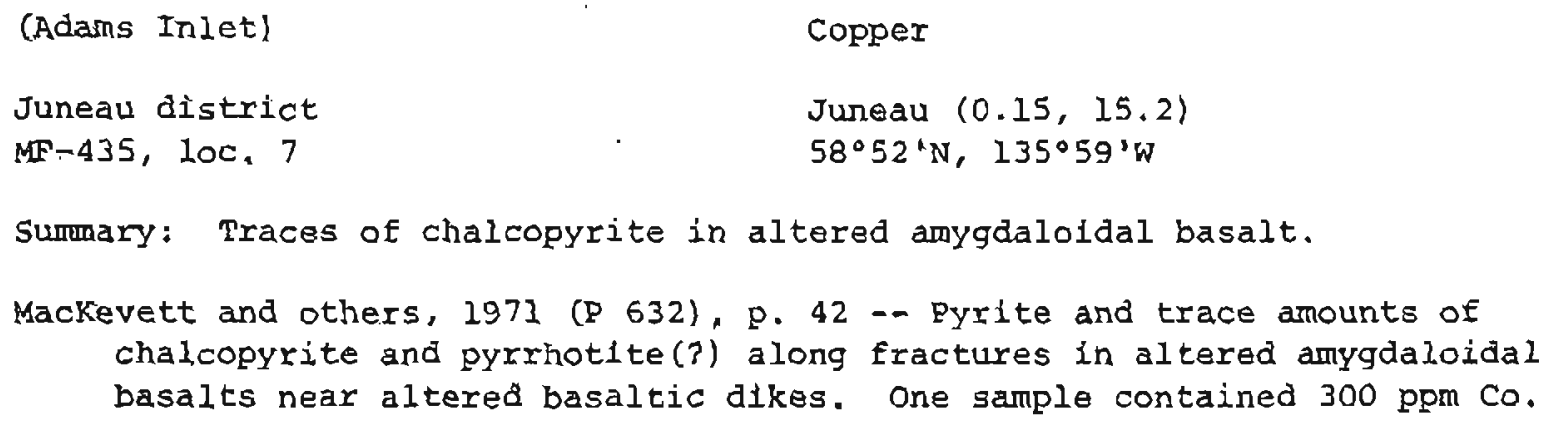


Admiralty-Alaska (Gola Mining Co.)

Admiralty district

MF-435, 100. 67
Cobalt, Copper, Gold, Lead, Molybdenum (?); Nickel, Zine

Juneau (10.2-10.75, 3.85-4.55)

$58^{\circ} 13^{\prime}-58^{\circ} 15^{\prime} \mathrm{N}, 134^{\circ} 50-134^{\circ} 54^{\prime} \mathrm{h}$

Summary: Country rock is mainly schist of various kinds; some phyllite and other metamorphlc rocks. Early development was of quartz veins mainly near sea level; mining begun before 1896 and (with neighboring Alaska-Dano and Hawk Inlet properties) accounted for 10,00015,000 fine oz. of gold. Minerals in veins included free gold, pyrite, pyrrhotite, galena, sphalexite, and chalcopyrite; molybdenite sample sent to USGS by owner probably did not come from this property. Gabbro pipe which plunges about $30^{\circ}$ eastward in quartz-mica schist (thermally metamorphosed 50-150 ft. from contact) and (above pipe only) phyllite. Pyrrhotite, pentlandite, and chalcopyrite concentrated in olivine-hornblende gabbro in keel of pipe; other gabbro (augite gabbro and norite) contains much less sulfide material. Extensively exploxed by crosscuts and drill holes. Resource is 500,000-600,000 tons of material containing $1 / 3$ to 1 percent each of copper and nickel. A little cobalt ( $(\mathrm{Ni} / \mathrm{Co}$ ratio 3.1-6.1) present. Includes references to: Boston \& Alaska Co., (Funter Bay), Mertie Lode, Pekovich, Tellurium, Willoughby.

Becker, 1898, p. 62-63 -- Minerals present at Willoughby (Tellurium) property include calcite, sericite, pyrrhotite; galena, not identified. p. 77-78 -- At Tellurium mine country rock is schist (probably originally a diabase). Quartz veins (with a little calcite) fill cross fractures in schist; veins contain much chlorite carrying free gold; also pyrite and pyrrhotite; some Eree gold in quartz; owner reported telluride, but this was not confirmed. Pyrite reported to contain $\$ 150$ a ton in gold and pyrrhotite $\$ 10-\$ 15$ a ton; ore said to average $\$ 10$ a ton. Boston \& Alaska Co. reported by mint to have produced $\$ 16,000$ labout 775 fine 02.] in gold in 1896.

Wright and Wright, 1905 (B 259), p. 55 -- Only assessment work since 1902. Tellurium mine consists of 2 shafts, each 100 ft. deep, and a 60-ft. tunnel on a quartz ledge several feet wide that cuts across chlorite schist. ore reported to average $\$ 8$ a ton.

Wright, 1906 (B 287), p. 149 -- 58 claims in 2 groups. First discovery (Tellurium claim) in 1887 ; fissure vein cutting across amphibole schist country rock; most of gold free; some pyrrhotite and pyrite; no tellurides; calcite and quartz gangue; 1,800 tons of ore reported to have been mined from underground and surface workings. Other group of claims is on mountain; Individual quartz ledges have been explored by prospect shafts and trenches [no data on metal content]. Chapin, 1916 (B 642), p. 76 -- Mining, 1915.

Smith, 1917 (BMB 153), P. 16 -- Being developed by Admiralty Alaska Gold Mining $C o$. in 1916. 
Admiralty-Alaska (Gold Mining Co, m Continued

EQkin, 1918 (B 662), p. 86r92 m 01d mill operated for 8 months testing ore from Tellurium and other clairs near beach, on which were somewhat less than 1,000 ft, of underground workings, several stopes, and many open cuts anö pits. On upper cluims are about $825 \mathrm{ft}$. of underground workings and a number of pits and stripped axeas. Lodes are all quartz veins that cut across cleavage and apparent bedding of schist country rock at high angles, schists adfacent to veins locally aln tered and contain sulfides and (reportediy) gola. Most abundant suln fides are pyrxhotite, pyrite, and galena; some sphalerite, Claims near beach appear to be mined out above sea level. Veins in upper group of claims appear to be more numerous and much larger than those near coast.

Martin, 1920 (B 712), p. 30 - Adit being dxiven, 1918.

Mertie, 1921 (B 714), P. 113-116 -- Tunnel driven about $800 \mathrm{ft}$. by midsumer, 1919. About $400 \mathrm{ct}$. from portal a zone of sheared quartz and schist with $8 \mathrm{in.}$ of quartz on hanging wall (parallel to cleavage of schist country rock) contains pyrite, pyrrhotite, and chalcopyrite.

Brooks, 1922 (B 722), p. 36-37 - Main adit extended about $650 \mathrm{ft}, 1920$. Also aany open cuts. New shaft begun.

Brooks, 1923 (B 739), p. 22 -n Exploration and development continued, 1921. Some ore mined and milled.

Brooks, 1925 (B 773), P. 12 -- Being developed near margin of small granitic area.

Buddington, 1925 (B 773), p. 72 -- Veins extend southward to williams property on Hawk Inlet.

p. 95 -Nickeliferous deposit has been found on property.

p. 109 -- Nickelíferous pyrrhotite found in olivine diabase dike that is partially exposed in a trench; about $50 \mathrm{ft}$. of width of dike appears to be exposed; weathered. Principal sulfide is pyrrhotite; also some pentlandite and chalcopyrite. Assays of 2 speclmens showed as much as $0.10 \mathrm{oz}$. per ton $\mathrm{Au}, 0.30 \mathrm{oz}$. per ton $\mathrm{Ag}, 1.18 \mathrm{zi}$, and $1.98 \% \mathrm{Cu}$,

Buddington, 1926 (B 783), p. 41-46 - Quartz fissure veins in greenstone schists that apparently are overlain by quartz-mica schists. Country rock cut by trachytic and dioritic dikes. Admiralty-Alaska property consists of about 100 claims. Crosscut tunnel extends 2,200 ft, (1924) from portal; about $200 \mathrm{Et}$. of exploratory dxifts have been dxiven from it. vein 1,250 ft. from portal is $2-3 \mathrm{ft}$, thick, but pinches out at end of 100me. drift; contains quartz, sparse sulfldes (pyrite, pyrrhotite, chalcopyrite, galena) and $\$ 4$ a ton in gold. Another vein exposed by a surface cut is as much as. $20 \mathrm{ft}$. thick, contains quartz, sparge sulfides (pyrite, pyrrhotite, chalcopyrite) and vory irxegularly distributed gold; assays as high as $\$ 200-\$ 300$ a ton reported. A troctolite dike that locally contains blebs of sulfides (pyrrhotite, pentlandite, chalcopyritel and magnetite.

smith, 1926 (B 783), p. 7 a- Prospecting, 1924.

Buddington and Chapin, 1929 (B 800), p. 348 -- Minerals carrying nickel and copper in troctollte or ollvine diabase dike; magnetite is a minor accessory. 
Admixalty-Alaska (Gold Míning Co.) -- Continued

Smith, 1929 (B 797), p. 11 -- 50-ton mill byought in, 1926.

Srith, 1930 (B 813), p. $14--5,400 \mathrm{ft}$. of diamond drilling, 1928.

Smith, 1932 (B 824), p. 16 -- Development continued; no production, 1929.

Smith, 1933 (B 836), p. 16 -- Development, 1930. A few test. runs in newly completed mill.

Smith, 1933 (B 844-A), p. 15-16 -- Prospecting, development, and a little production, 1931 .

Smith, 1934 (B 857-A), p. 15 -- Some production, 1932. Admiralty-Alaska Gold Mining Co. took option on claims extending to Hawk Inlat.

Smith, 1934 (B 864-A), p. 17 -D Development and equipment renovation, 1933. Smith, 1936 (B 868 A), p. 16 -- Productive work, 1934.

p. 82-83 -- Have been extensive tests of nickel-bearing dlabase sill (sulfides of iron, copper, and nickel, plus some gold and silver); estimates by engineers are that there may be as much as 5,000,000 tons of raterial containing not less than $1 \% \mathrm{Ni}$.

Snith, 1937 (B 880-A), p. 17 - No productive mining, 1935.

Smith, 1938 (B 897-A), p. 17 -- No productive mining, 1936.

Reed, 1939 (B 897-D), p. 263-268 -- Troctolite (according to Buddington) sill is about $126 \mathrm{ft}$. thick and between a siliceous schist hanging wall and a greenstone schist footwall. Contains magnetite, ilmenite, pyrrhotite, chalcopyrite, and pentlandite. Explored by 110-ft. tunnel and diamond-arill holes. Chemical analyses indicate higher $\mathrm{Cu}$ and $\mathrm{Ni}$ contents than would be expected from petrographic studies. Excess $\mathrm{Ni}$ may be in olivine.

Smith, 1939 (B 910-A), p. 19 - No productive lode mining, 1937.

Smith, 2939 (B 927-A), p. 19 - No productive mining, 1938.

p. 105 - Reference to Reed, 1939 (B 897-D).

Smith, 1941 (B 926-A), p. 18 - No productive mining, 1939.

Reed, 1942 (B 936 O), p. 349-361 -- Basic sill in a thlck sequence of phyllite and various kinds of schist (many probably of igneous origin) averages somewhat more than $100 \mathrm{ft}$. in thickness: composed principally of labradorite and olivine; contains generaliy less than 28 metailic minerals (magnetite, pyrxhotite, chalcopyrite, and pentlandite); reserve is estimated about 560,000 tons of material with average contents of $0.34 \mathrm{Ni}$ and $0.35 \% \mathrm{Cu}$. Significant parts of the copper and nickel probably are not in the chalcopyrite and pentlandite: probably in olivine and perhaps in pyxrhotite. Grade too low and tonnage too small for profitable mining or to be a significant contribution to U.S. nickel supPly.

Smith, 1942 (B 926-C), P. 174 -- A specimen of molybdentte was received from W. S. Pekovich; may have core from Funter Bay area. J. C. Reed has found no molybdenite on Admixalty I. Location of occurrence questionable.

Smith, I942 (B 933-A), P. 17 - No production mining, 1940.

Bain, 1946 (IC 7379), p. 70-71 - Reference to Reed, 1942 (B 936-0). In 1942 USBM took a large sample from Mertie lode for metallurgical testing. 14 channel samples taken over a 90-ft. section in adit in 1943 averaged $0.468 \mathrm{Ni}, 0.418 \mathrm{Cu}, \$ 0.40 \mathrm{a}$ ton in gold and silver, and a little cobalt. Ni/Co ratio ranged from 3.1 to 6.1 . 
Admiralty-Alaska (Gold Mining Co.) -- Continuea

Holt and Moss, 1946 (RI 3950) -- Mainly details of various sampling programs and USBM beneficiation tests; Mertie lode only. Data fror drill-hole cores and samples from adit are not consistent. Identified minerals are pyrrhotite, pentlandite, chalcopyrite, purite, and sphalerite. USBM petrologist reported violarite rather than pentlandite. Most of data surmarized in Bain, 1946 (IC 7379), p. 70-71. Twenhofel, 1953 (C 252), p. 7 -- Nickel deposit is second largest known in Alaska. Olsseminated pyrrhotite, pentlandite, and chalcopyrite in a sill (?) composed of felospar and olivine. Grade is about $0.45 \% \mathrm{Ni}$ and $0.4 \% \mathrm{Cu}$; very little gold, silver, and cobalt. Estimated to contain at least 500,000 tons.

West and Benson, 1955 (B 1024-B), p. 51-52 -- Country rocks are greenstone, many kinds of schist, phyllite, gneiss, and marble cut by dikes and silis of diabase, gabbro, granite, syenite, and trachyte. quartz veins contain gold, pyrite, galena, sphalerite, chalcopyrite, and arsenopyrite. Gabbro sill contains pentlandite, chalcopyrite, and pyrrhotite. No radioactive anomalies were found.

Lathram and others, 1960 (I-323) -- Map shows symbols for occurrences of gold, copper, lead-zinc, nickel-cobalt.

Bilbrey, 1962 (IC 8103), p. 27 -- Low-grade copper-nickel carries a little cobalt. Assays range between 0.07 and $0.23 \mathrm{Co} 0.26 \% \mathrm{Ni}$, and $0.3 \%$ $\mathrm{Cu}$.

Barker, 1963 (B 1155), P. 1-10 -- Gabbro pipe with cross-sectional areas normal to pipe axis of about $22,000 \mathrm{sq}$. ft. at the surface and about 8,000 at DMEA adit level $360 \mathrm{ft}$, along axis below surface; enlarges farther down axis to elliptical cross section with axes of $190 \mathrm{ft}$. and $125 \mathrm{ft}$. Pipe plunges about $30^{\circ}$ at $\mathrm{S} 80^{\circ} \mathrm{E}$. Olivine-hornblende gabbro is potential ore material; augite gabbro and norite are not. country rock is quartz-mica schist (thermally metamorphosed for 50-150 $\mathfrak{t}$. from contact) around most of pipe; black phyllite above pipe near surface. Sulfides are pyrrhotite, pyrite, pentlandite, and chalcopyrite; concentrated in olivine-hornblende gabbro in keel of pipe; in typical piece of material sulfides make up 32.5\% of rock by volume; mainly pyrrhotite; $2.6 \%$ pentlandite and $2.5 \%$ chalcopyrite, most of which apparent1y exsolved from pyrrhotite. Best material is in a mass $360 \mathrm{ft}$. by $60 \mathrm{ft}$. by $40 \mathrm{ft}$; believed to contain 1.28 combined nickel anä copper. Exploration 1950-56 consisted of 1,093 ft. of crosscutting, 309 it, long-hole arilling, and 5,742 ft. of dimond drilling, plus cutting underground drill stations.

Herbert and Race, 1965 (GC 6), p. 33 -- Reference to Barker, 1963 (B 1155), p. 1-10. Assay values of samples of copper-nickel deposit were 0.58 to $1.0 \%$ each of copper and nickel.

Lathrom and others, 1965 (B 1181-R), P. R43 -- Sulfide minerals in a pluglike mafic intrusive body; ore minerals (pentlandite and chalcopyrite) form veinlets that coalesce to make up masses of noarly solid sulfide ore.

Noel, 1966, p. 65 - Gabbro pipe which plunges at about $30^{\circ}$ to east in highIy folded schist and phyllite. Pyrrhotite, pentiandite, and chalcopyrite as veinlets and disseminited grains mainly along keel of pipe, Estimated reserves greater than 500,000 tons grading $0.458 \mathrm{Ni}$ and 0.48 Cu. 
Admiralty-Alaska (Gold Mining Co.) -- Continued

Berg and Cobb, 1967 (B 1246), P. 137, 140 -- Gold lodes discovered before 1900 produced (combined with production from Alaska-Dano and Hawk Inlet) 10,000-15,000 oz. of gold Erom quartz veins in metamorphic rocks. Mertie lode is a nickel- and copper-bearing gabbro pipe; in places pyrthotite, pentlandite, chalcopyrite, and pyrite make up nearly one-thlrd of the rook; extensively explored. Material used for USBM beneficiation tests contained $0.26 \% \mathrm{NI}, 0.308 \mathrm{Cu}$, and $0.07 \% \mathrm{Co}$. No commercial production from Mertio lode.

Race and Rose, 1967 (GC 8), p. 4 -- Copper-nickel mineralization associated with a gabbro plug.

p. 15 -- Geockemical sampling did not show appreciable nickel.

p. 19-20 -- Deposits were (1) free gold, pyrite, and pyrchotite with gold in quartz-filled fissures and veins in amphibole schist developed by two 100-ft. shafts and connecting crosscuts; (2) gold in quartz ledges and thin seams in schist and slate developed by 70-ft. shaft and several tunnels; and (3) pentlandite and chalcopyrite in a pluglike mafic intrusive body in schist developed by over 3,000 ft. of tunnels, dxifts, and crosscuts. Total production (including that of Alaska Dano\} was $\$ 100,000$ [about 4,840 fine oz.] in gola.

Cornwall, 1968 (B 1223), p. 13 -- Table headed "Marginal and submarginal nickel resources of North America;" grade $18 \mathrm{Ni}$.

p. 37-38 -- Data from Reed. 1942 (B 936-0) and about the same as Barkar, 1963 (B 1155), D. I-10. Small to moderate tonnage of naterial averaging 1 \& $\mathrm{Ni}$ and $1 \% \mathrm{Cu}$.

Cornwall, 1973 (P 820), p. 440 -- Identified reserve is 600,000 cons of ore with $0.358 \mathrm{Ni}$. 
Alaska Atlin Mining Co.

Juneau district
Gold(?)

Juneau

SE $1 / 4$ quad.

Sumary: Gold(?) property on Douglas I. Little if any development.

Wright, 1907 (B 314), g. 54 -- Property has been idle for several years [as of 1906]; no improvements of consequence. On Douglas $I$. 
Alaska Dano (Mines Co.I

Aamiralty district

$M F-435,10 c, 68$
Copper, Gold, Lead, Silver, zinc(?)

Juneau $(10,25-10,6,3,55-4,15)$

$58^{\circ} 12^{\circ}-58^{\circ} 14^{\prime} \mathrm{N}, 134^{\circ} 52^{\prime}-1.34^{\circ} 54^{\prime} \mathrm{W}$

Sumary: Quartz fissure veins in mica and chlorite schists contain pyrite, pyrrhotite, galena, chalcopyrite, secondary ixon and copper min exals, and free gold; some high silver assays reported. One reference reports zinc blende (sphalerite). Depasits aiscovered and development begun before 1900. By 1900 there were two shafts (about $50 \mathrm{ft}$. and $125 \mathrm{ft}$. deep) and $320 \mathrm{ft}$ of arifts; handsorted ore that was mined is said to have run doout 4.85 oz. gold a ton. Later subsurface exploration amounted to about $265 \mathrm{tt}$. of tunnels; production was 2 small shipments that contained about 5.8 and 3.9 oz. gold a tom. Total proquetion probably no more than $100 \mathrm{oz}$. of gold. Includes references to: Nowell-Otterson, Otterson, War Horse.

Becker, 1898, P. 62-63 - Chlorite and zincblende present at war Horse. P. 77-78 -- Quartz veins in schist; pyritiferous quaxtz lenses in slate.

Wright and Wright, 1905 (B 259), p. 55 -- War Horse mine was extensively developed in 1897 and again opexated in 1900. Quactz ledge $2 \mathrm{ft}$. wide; rich in disseminated free gold. Developed by 2 shatts (48 ft. and $125 \mathrm{ft}$. deepl and $320 \mathrm{ft}$. of drifts. Mand-sorted ore said to have run about $\$ 100$ a ton.

Wright, 1906 (B 287), p. 149 - Same as Wright and Wright, 1905 (B 259), p. 55.

Eakin, 1918 (B 662), P. 85 -- Otterson group of claims held in 1916.

p. 92 -- Well-defined quartz veins $20 \mathrm{ft}$. or less wide; gold as sociated with sulfices. Specimens show visible gold in quartz and in pyrrhotite in quartz. Prospecting, 1916.

Mertie, 1921 (B 714), P. 113 -- Prospecting, 1919.

p. 116-118 - Many quartz veins, some paraljel to and others cutting across the schistosity of variety of mica and chlorite schists. Minerals in veins include pyrite, pyrrhotite, galena, chalcopyrite, secondary iron and copper minerals, and gold, some assays indicate hugh silver values. At least 2 prospect tunnels have been driven a total of 264 ft. Two small ore shipments ran $\$ 120$ and $\$ 80$ [about 5.8 and $3.90 z$, of gold l a ton.

Brooks, 1922 (B 722), P. 37 - A little work, 1920.

Brooks, 1923 (B 739), p. 22 -- Development work, 1921.

Brooks, 1925 (B 773), P. 12 -- Being developed near maxgin of small granitic body.

Buddington, 1926 (B 783), p. 41-44 - Quartz fissure veins mainly in greenstone schists; some quartz schist on property.

Smith, 1926 (B 783), p. 7 -- Prospecting, 1924.

Smith, 1929 (B 797), p. 11 -- Prospecting, but no production, 1926.

Smith, 1932 (B 824), p. $16-$ A little development (76 ft. of tunnel), 1929. Berg and Cobb, 1967 (B 1246), P. 137 - Lodes discovered before 1900.

Race and Rose, 1967 (GC 8), p. 20 -- 2-ft, quartz ledge contains free gold: developed by 2 shafts and $300 \mathrm{ft}$. of drift. 
Alaska Endicott (Mining \& Milling Co-) Copper, Gold, Silver

Juneau district

Juneau $(6.8,12.25)$

MF-435, LOC. 11

$58^{\circ} 42^{\prime} \mathrm{N}, 135^{\circ} 15^{\prime} \mathrm{W}$

Sumary: Eaulted quartz-breccia vein about $10 \mathrm{ft}$. wide in greenstone tuff and lava flows. Principal metallic mineral is chalcopyrite; accompanied by a little pyrite and low values in gold ano silver. Workings consisted of about 2,400 ft. of adits, drifts, and raises and 3 small stopes. By 1919200 tons of ore was mined; yielded $48.38 \mathrm{oz}$. gold and $20 \mathrm{oz}$. silver. No data on copper returns. Mined ore probably contained at least 8 sulfides; what remains contains less than 2 sulfides. Prospecting and development Erdm 1915 or 1916 to about 1923. Shipment of copper ore in 1923. reported: no data on amount or copper content. Includes references to: Endicott-Alaska Mining \& Milling Co., Endicott (Mining \& Mililng Co.). See also (William Henry Bay).

Chapin, 1916 (B 642), p. 76 -- Company fomed to develop a group of claims at William Henry Bay, 1915. [This probably refers to Alaska Endicott rather than to othex occuryences in general area.]

Martin, 1920 (B 712), g. $30 \sim$ Adit driven 26 ft. and 250 ft. of drifts run on vein, 1918.

Brooks, 1921 (B 714), p. 19 -- Copper in shear-zone deposit.

Mertie, 1921 (B 714), P. 109-122 -- Rocks in genexal area are highly contorted limestone with interbedded argillite, chert, greenstone flows, greenstone tuffs, and graywacke derived from greenstone, all cut by diabase dikes. Country rock at prospect is greenstone tuff with interbedded lava flows cut by an augite minette dike. Copper lode is chalcopyrite and quartz and chalcedony veinlets in a calcite vein that averages about $10 \mathrm{ft}$. in thickness. Assumption is that $2{ }^{4}$ copper ore can be produced; only snall quantities of gold or silver. Tunnel is $1,100 \mathrm{ft}$. long, the last $400 \mathrm{ft}$. in the vein; many small-aisplacement faults encountered. Nearby is a similar, but much smaller, vein. Mill purchased; to be installed in 1920.

Brooks, 1922 (B 722), P. 37 -- Underground work continued; preparations for erecting mill; 1920.

Brooks, 1923 (B 739), p. 22 -- Underground work continued; about 1,800 ft. has been done; installation of mill begun; 1921.

Brooks and Capps, 1924 (B 755), p. 25 -- According to newspaper reports mill was completed in November 1922 and operations were begun before end of the year.

Brooks, 1925 (8 773), o. 38 -- Shipments of copper ore, 1923.

Twenhofel and others, 1949 (B 963-A), $9.28-30$-- Deposit is a quartz breccia vein that dips about $70^{\circ} \mathrm{S}$; many angular Eragments of partly replaced greenstone: vein boundaries indistinct; pinches and swells; offset by many small-displacement faults; vein faulted off $1,350 \mathrm{ft}$. from portal of tunnel; could not be found again. Principal ore minerals are chalcopyrite and pyrite. All production was gold and silver; by 1919 had mined 200 tons of ore that contained $48.38 \mathrm{oz}$, gold and 20 oz. silver (combined value of $\$ 2020$ ). Workings consisted of about $2,400 \mathrm{ft}$, of adits, drifts, and raises and 3 small stopes. 
Alaska Endicott (Mlning \& Milling Co.) -- Continued

Herbert and Race, 1964 (GC 1), p. 10 -- Data in Herbert and Race, 1965 (GC 6).

Herbert and Race, 1965 (GC 6), p. 25 -- Before 1919 over a thousand feet of drifts and tunnel were driven. Shipments returned $\$ 1,020$ in golo and silver; no report on value of copper recovered.

Berg and cobb, I967 (B 1246), p. 162 -- Produced 200 tons of ore from which a total of about $50 \mathrm{oz}$. gold and $20 \mathrm{oz}$. silver was recovered. Lode is in Paleozoic greenstone and consists of chalcopyrite and pyrite in a faulted quartz-breccia vein. Materlal mined probably contained at least $8 \%$ sulfides; what is left contains less than $2 \%$.

Eakins, 1975 (GR 44), p. 15 -- Development between 1916 and 1920 . Ore zone cuts greenstone country rock and consists of an irregular quartzcalcite zone; average width $10 \mathrm{ft}$. Ore mineral is chalcopyrite with pyrite and traces of gold and silver. 1,800 ft. of tunneling and some stopes. 
Alaska-Juneau (Gold Mining Co.)

Juneau district

$M E-435$, locs. 48-50
Copper, Gold, Lead, Silver, zinc

Juneau $(15.0-15.35,5.4-5.6)$

$58^{\circ} 18^{\prime}-58^{\circ} 19^{\prime} \mathrm{N}, 134^{\circ} 20^{\prime}-134^{\circ} 22^{\prime} \mathrm{W}$

Sunmary: Lode systern is a network of quartz veins from a few inches to 2-3

Feet thick in footwall part of Perseverance slate near intrusive metagabbro sills and in the sills (Herreid considers possibility that sills are tuff beds altered to amphibolite); veins especially concentrated near ends of silis where they interfinger with slate. System is about $300 \mathrm{Et}$. wide and $3-1 / 2 \mathrm{mi}$. long; divided into 2 sections by transverse nomal silverbow fault. Deposit discovered and staked in 1880. Some early production from residual placers on outcrops of lode. Developed as a large-volume low-grade proposition; veins did not have enough continuity for selective mining. Veins carry, in addition to gold, pyrite, pyrxhotite, arsenopyrite, galena, sphalerite, chalcopyrite, and considerable silver. Developed by miles of underground workings and glory holes. Mili very efflcient; practice involved hand sorting of ore defore miling. In 1924 began operating adjoining Ebney mine on royalty basis; took over adjoining Perseverance mine in 1934; both mined through Alaska-Juneau workings as integral parts of Alaska-Juneau. AlaskaJuneau closed in 1944; total production from mining, 1893-1944, (including that from Ebner and Perseverance after they were connected to Alaska-Juneau) and a little from clean-up operations of rill after mine closed was $2,888,296$ oz. gold, 1,949,810 oz. silver, and $40,219,231 \mathrm{lb}$. lead (valued by company at $\$ 81,020,841$ ) from $88,466,078$ tons of ore, of which $47,192,108$ was milled. Includes references to: Bennet, Lane \& Hayward. See also: Ebner, Perseverance.

Becker, 1898, p. 62-63 -- Calcite, mispickel, pyrrhotite, siderite, and zinc blende present at Bennet or Lane \& Hayward properties.

p. 71-73 -- Auriferous saprolite on higher parts of property was not removed by glacial action; has been worked as a placer. Bedrock is schist with many small quartz stringers cut by at least 3 fine-grained diorite dikes. At lane \& Hayward property there is much $\$ 4-\$ 5$ a ton material; some as rich as $\$ 8$ a ton. Gangue minerals include pyrite, arsenopyrite, galena, and sphalerite. At Bennet property pyrrhotite is also present; ore mills out at about $\$ 13$ a ton; vein $2-6 \mathrm{ft}$. thick followed for $200 \mathrm{Ft}$. underground.

Spencer, 1904 (B 225), p. 29-30 -- Productive mine in 1903.

p. 35 -- In mineralized zone about $800 \mathrm{Et}$. wide in black slate. Wright and Wright, 1905 (B 2591, p. 53 - Work continued, 1904.

Spencer, 1906 (B 287l, p. 58 -- Best ground staked in Oct. 1880.

p. $69-73=-$ stringer leads of quartz, mainly in black slate; some in diorite. Slate belt between greenstone footwall followed by diorite dike and hanging-wall fault between a diorite dike and schist. Gangue minerals in veins are mainly quartz and, to a lesser extent, carbonates. Principal sulfides are mainly pyrrhotite and pyrite; sphalerite, galena, chalcopyrite, and arsenopyrite also present. Some of gold is native, 
Alaska-Juneau (Gold Mining Co.) -- Continued

but most is in sulfides, as is all of silver. Glory-hole [term not used] mining; gold production through 1903 worth about $\$ 100,000$.

Wright and Wright, 1906 (B 284), p. 37 -- Mining and development, 1905.

Wright, 1907 (B 314), p. 55 -- Mining, 1906.

Wright, 1908 (B 345), p. 87-88 -- Mining, 1907.

Wright, 1909 (B 379), p. 70 -- Mining, 1908.

Knopf, 1910 (B 442), p. 135 -- Mining, 1909. Where feasible ore was sorted before milling.

Knopf, 1911 (B 480), p. 96 -- Mining, 1910.

Brooks, 1912 (s 520), p. 25 -- Mainly sampling and much preparatory work, 1911

Brooks, 1913 (B 542), p. 32 -- Mining, 1912.

Brooks, 1914 (B 592), P. 59 -- Snowslide Gulch adit completed and raise put through to surface, 1913-14. New mill begun.

Brooks, 1915 (B 622), D. 41 -- Part of new mill operated, 1914.

Eakin, 1915 (B 622), p. 96, 98 -- New era of development in full swing, 1914.

p. 100 -- 200 men employed preparing for large-scale mining, 1914. Mill operated 50 stamps for testing ores and milling procedures.

Chapin, 1916 (B 642), p. 75-76 -- Plans for $\$ 2,500,000$ to be spent on mill and mine development and improvement.

p. 98 -- Lead produced from galena concentrate.

Smith, 1917 (BMB 142), p. 32-33 -- Ore taken to mill through 6,538-ft.-long Gold creek tunnel, from mouth of which it is trammed on surface and through short tunnels, 1915.

Smith, 1917 (BMB 153), p. 18-19 -- Ore is in a shear or fracture zone that is cut by silver Bow fault to make 2 ore bodies. Average comercial width of ore zone is about $400 \mathrm{ft}$.; throw of silver Bow fault is about 2,000 et. Most of reference 15 on mining methods,

Eakin, 1918 (B 662), p. 77 -- Active operation, 1916.

p. 80-81 -. Much development in both north and south ore bodies; new mill urder construction, 50-stemp mill operated at capacity most of year, 1916.

Martin, 1919 (B 6921, p. 29 -- Mining, 1917. Mill operated at half capacity, Martin, 1920 (B 712), p. 29 -- Mining on a reduced scale, 1918, Mill will have to be redesigned.

Mertie, 1921 (B 714), P. 106-107 -- Mining, 1919. Changes in mill and introduction of some hand sorting of ore.

Brooks, 1922 (B 722), p. 36 -r Mining, 1921.

Brooks and Capps, 1924 (B 755), p. 8 - Increased output in 1922 over that in 2921,

p. 24 -- Mining, 1922. Production to date is $\$ 5,431,526$ labout 262,773 fine oz.] in gold, 162,914 oz. silver, and 2,833,139 lbs, lead. Brooks, 1925 (B 773), p. 14-15 -- Mining, 1923.

P. 37 - Only large mine in southeastern Alaska that has been operated continuously since it was opened.

Smith, 1926 (B 783), P. 6-7 -- Mining, 1924. Took over development of Ebner; expect to be mining $I, 000$ tons a day by Noverber, 1925.

p. 22 - Produced 1,256,857 1b. lead, 1924.

Moffit, 1927 (B 792), p. 9 ar Mining, 1925. Also did preparatory work at Ebnex mine. 
Alaska-Juneau (Gold Mining Co.) -- Continued

p. 29-30 -- Produced 1,288,974 1b. lead, 1925.

Smith, 1929 (B 797), p. 9-10-- Mining, 1926.

p. 38-39-- Produced $1,300,915$ lb. lead, 1926.

Smith, 2930 (B 810), p. 10-12 -- Mining, 1927.

p. 48 -- Produced 51,232 oz. silver, 1927.

p. 51 -- Produced 1,513,306 lb. lead, 1927 .

p. 63 -- Mill being equipped to recover zinc, 1927.

Smith, 1930 (B 813), p. 12-13 -- Mining, 1928. Acquired physical proper-

ties in Alaska of Treadwell group of companies.

p. 55 -- Produced 77,591 oz. silver, 1928.

p. 58 -- Produced 2,038,655 1b. lead, 1928.

Smith, 1932 (B 824), p. 13-14 -- Mining, 1929.

p. 61 - Produced 90,635 oz. silver, 1929.

p. 64 - Produced 2,501,832 1b, lead, 1929.

Smith, 1933 (B 836), p. 12-14 -- Mining, 1930. Secured options on 2

groups of claims.

D. 63 -- Produced 97,607 oz. s1lver, 1930.

p. 56-67 -- Produced 2,640,771 1b. lead, 1930.

Smith, 1933 (B 844-A), P. 13-14-- Mining, 1931. Exploration of Fallam and Dora claims; also some work on claims at west Hill and near Tulsequah $R$, in Canada.

p. 62 -- Produced 118,508 oz. silver, 1931. 1931.

p. 65 -- Source of most of Alaska lead production (1,660 tons),

Smith, 1934 (B 857-A), p. 12-14 -- Mining, 1932. Option on Hallam and Dora dropped. Some work on claims in Canada. 1932.

p. 58 -- Pxoduced 94,519 oz. silver, 1932.

P. 61 -- Source of most of Alaska lead production (1,261 tons),

Smith, 1934 (B 864-A), p. 13-14 -- Mining, 1933. Canadian work ceased.

p. 63 -- Produced 109,483 oz, silver, 1933. 1933,

p. 66 -- Source of most of Alaska lead production $(1,157$ tons),

Smith, 1936 (B 868-A), p. 13-15 -- Mining, 1934. Acquired Perseverance ana began expanding into Perseverance ground.

p. 61 -- Produced 86,458 oz. silver 1934. 2934.

p. 68 - Source of most of Alaska lead production (840 tons),

Smith, 1937 (B 880-A), p. 13-16 -- Mining, 1935. Decrease in production because of a strike, Considerable work getting Perseverance ready for mining. Also promotion of a plan for a new company to Investigate old Treadwell properties.

P. 64 -- Produced $77,787 \mathrm{oz}$. of sliver, 1935.

P, 71-72 -- Source of most of Alaska lead production (815 tons). 1935.

Smith, 1938 (B 897-A), p, 14-16 -- Mining, including ore from Perseverance, 1936.

p. 74 - Produced 101,591 cz. silver, 1936.

p. 81 - Source of most of lead produced in Alaska $(1,058$ tons), 1936. 
Alaska-Juneau Gold Mining Co.) -- continued

Smith, 1939 (B 910-A), p. 16-18 -- Mining, 1937.

p. 79 -- Produced 120,691 oz, silvex, 1937.

p. 86-87 -- Source of most of Alaska lead (1,002 tons), 1936.

Smith, 1939 (B 917-A), p. 17-19 -- Mining, 1938.

p. 78 -- Produced 121,473 oz. Silver, 1938.

p. 88-89 -- Source of nearly all lead produced in Alaska $(2,224,000$ 1b.) 1938 .

Smith, 1941 (B 926-A), p. 16-18 - Mining, 1939. 44s of ore milled came

from Perseverance.

P. 72 -.. Produced 111,494 oz. silver, 1939.

p. 81-82 -- Source of nearly all lead produced in Alaska $(2,120,000$ 1b.), 1939 .

Smith, 1942 (B 933-A), P. 15-17 -- Mining, 1940.

p. 69 -- Produced 100,633 oz. Silver, 1940.

p. 78-79 -- Source of neariy all lead produced in Alaska $(1,680,000$ lb. $), 1940$.

Smith, 1944 (B 943-A), p. 8-9 -- Mining, 1941-42. Total production, 18931942, was $2,834,358$ oz. gold, 1,904,064 oz. silver, and $39,711,231$ b. lead; worth $\$ 79,033,962$ by company's valuation. Total ore mined was $86,625,448$ tons of which $40,572,603$ tons was rejected coarse tailings.

p. 14-15 -- Data on silver and lead production.

Bain, 1946 (IC 7379), P. 14-20 -- Historical summary; largely economic. Mine and mill shut down early in 1944. Operations in 3943-44 were greatly curtailed and were at a deficit.

p. 34 -- Normal lead output was about 900 tons.

Twenhofel, 1952 (OF 60), p. 4-5 -- Total production of mines in AlaskaJuneau lode system, 1893-1947, was worth about $\$ 92,000,000$.

p. 12-28 -- Historical data on Alaska Juneau and other mines (Ebner, Perseverance) in lode system. Total production of AlaskaJuneau (including the company's production from Ebner and Perseverance while operating them as parts of Alaska-Jureau mine and mill clean-up after mine closed) was $2,888,926 \mathrm{oz}$. of gold, 1,949,810 oz. of silver, and $40,219,231 \mathrm{lb}$. of lead (total value $\$ 81,020,841$ [in current dollars\} from $88,466,078$ tons of ore trammed, of which 47,192,108 tons was milled. Average yield of ore trammed was $\$ 0.91$ a ton and of ore milled was $\$ 1.72$ a ton. Total value of production from lode system (including placer gold Erom Gold $\mathrm{Cr}$. ) was $\$ 93,682,681$.

p. 33-38 -- Data on power plants.

p. 45 - Alaska-Juneau lode system is a network of quartz veins in the Perseverance slate near slate and metagabbro contacts; values (gold, silver, lead) confined almost entirely to veins.

p. 88 - Most ore bodies are "at end or prong of a meta qabbro hodv in both the meta-gabbro and "the surrounding slate."

p. 129-167 -- Lode system is $300 \mathrm{ft}$. wide and $3-1 / 2 \mathrm{mi}$. long in Footwall portion of Perseverance slate where metagabbro sills invaded the slate. Both slate and sills injected by quartz veins; most abundant in and near ends of sills where they interfinger with slate. Yeins carry values in gold, silver, and lead. System divided into 2 parts by the postmineralization transverse silverbow nozmal fault; Ebner and Alaska-Juneau North Ore Body north of fault; Perseverance 


\section{Alaska-Juneau (Gold Mining Co.) -- Continued}

and Alask-Juneau South Ore Body south of fault. Shape of ore bodies irregular; assay walls. Veins from a few inches to 2 or $3 \mathrm{ft}$. wide constitute the ore; wall rock essentially barzen. Veins consist of more than $95 \%$ quartz with ankerite, pyrrhotite, arsenopyrite, galena. sphalerite, chalcopyrite, and gold. Mined in blocks and barren slate and metagabbro removed by hand sorting.

Caufman, 1958 (IC 7844), p. 7 -- Approximately $\$ 80.8$ million in gold. silver, and lead was recovered, 1893-1944.

Herreia, 1962, p. 64-65 -- Amphibolite may represent tuff layers rather than intrusive bodies; are parallel to bedding of metasediments. Location of ore-bearing veins closely controlled by fold structures; . most common in axial-plane zone.

Noel, 1966, p. 54 -- Largest gold producer in soltheastern Alaska. $\$ 80,000,000$ in gold, silver, and lead from milling $88,500,000$ tons of ore with average grade of $0.0432 \mathrm{oz}$. gold pex ton between 1893 and 1944. [See Twenhofel, 1952 (OF 60), p. 12-28 for more detalied production data.]

p. 60 -- Parallel quartz stringers (a few inches to several feet wide; little individual strike length) in phyllite, slate, and amphibolite; quaxtz and(or) calcite with pyrite, galena, sphalerite, and chalcopyrite. Reference to and data from Herreid, 1962.

Berg and Cobb, 1967 (8 1246), p. 154-155 -- Slate containing swarms of quartz veinlets carrying gold, pyrrhotite, sphalerite, galena, pyrite, arsenopyrite, chalcopyrite, and tetrahedrite.

U.S. Bureau of Mines, 1967 (IC 8331), p- 6-7 -- Metamorphosed sediments and irregulax intnusions of metagabbro; gold irregularly distributed in irregularly distributed quartz stringers and gash veins in slate and metagabioro.

Koschrann and Bergendah1, 1968 (B 610), p. 19-2l - source of bulk of gold produced in Southeastern Alaska region. Deposit discovered I880; production, 1893-1944, was $2,874,361$ oz. gola, almost as much silver. and large quantities of lead.

Thorne, 1969 (UBSM of 22-69), p, 33 -- With Treadiell group produced gold and sllver valued at more than $\$ 148$ million from about 1,7 milition tons of oxe. Mine operated 1893-1944.

Cobb, 1973 (B 1374), P. 103 - Lode discovered in 1880 by following placer gold up Gold Cr.

Simons and Prinz, 1973 (P 820), p. 267 -- Example of gold-quartz lode, widespread and pervasive wallrock alteration. Production in range of 2-5 million ounces.

p. 273 - Average grade about 0.04 oz, per ton (a iittle more than 1 epm). 
(Alaska-Juneau dunp)

Jureau district
Gold, Lead, Tungsten, zinc

Juneau $(14.8,5.2)$

$58^{\circ} 17^{\prime} \mathrm{N}, 134^{\circ} 22^{\prime} \mathrm{W}$

Sumary: Heavy minerals in slulce-box concentrate included sphalerite, galene, gold, and scheelite. A little gold has been slulced Erom tailings.

West and Benson, 1955 (B 2024-B), p. 53 -- Heavy minerals in sluice-box concentrate included magnetite, pyrite, sphalexite, ankerite, limonite, galena, gold, ilmenite, zircon, and scheelite.

cobb, 1973 (B 1374), p. 103 -- A little gold has been recovered by sluicing tailings from mill. 
Alaska-Taku

Juneau district
Gola(?)

Juneau $(16.3,4.8)$ approx.

$58^{\circ} 16^{\prime} \mathrm{N}, 134^{\circ} 15^{\prime} \mathrm{W}$ approx.

Sumary: 43 lode claims and 8 mill sites. Deposits said to be stringer lodes. No other data. No mention of these claims except in report of developments in 1915.

Chapin, 1916 ( $B$ 642), p. 76 - 43 lode claims and $8 \mathrm{mill}$ sites located and being developed, 1915. Deposits (not examined by Chapin) said to be stringer lodes similar to Perseverance lode. Near Grindstone and Rhein Creeks. 


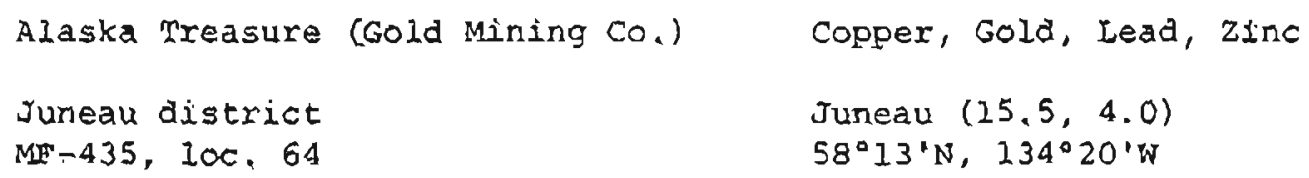

Summary: Country rock is greenstone and greenstone schist with some intercalated slate. Ore is in narrow bands and consists of quartz and calcite veinlets, auriferous pyrite, chalcopyrite, galena, sphalerite, and tetrahedrite (?). Part of a mineralized and altered area mile wide and $1-1 / 2 \mathrm{mi}$. Long; ore zone is $90 \mathrm{ft}$. wide and traceable on surface for 2,000 ft. As of 1914 there were $3,650 \mathrm{ft}$. of development work, $365 \mathrm{ft}$. of which was in are. Mill test of 1 ton of picked ore indicated $\$ 2.95$ in gold by amaIgamation, $\$ 3.92$ in sulfides, and $\$ 0.20$ in tailings; total of \$7.07 (about $0.34 \mathrm{oz}$. ) per ton. Little if any work aftex 1916. Production not known, but probably smal2; must have been some, as the mine had its own mill. Includes references to: Alaska Consolidatod Mining Co., Alaska Treasure Consolidated Mines Co., Nevada Creek, (Nevada Cr.l.

Spencer, 1904 (9 225), p. 40-41 -- Bleached zone in greenstone; locally narrow, irregular veinlets carry galena and sphalerite with more gold and silver than in the country rock. No well-defined ore bodies have been discovered.

Spencer, 1906 (B 287), P. 92-93 -- Mill test of I ton of picked ore indicated $\$ 2.95$ in gold by aralgamation, $\$ 3.92$ in gold in sulfides, and $\$ 0.20$ in gold in tailings, or a total of $\$ 7.07$ [about 0.34 fine oz.] per ton. Assays of samples from Corbus tunnel indicated from a trace to $\$ 8.20$ a ton.

Wright and wright, 1906 (B 284), p. 39-40 -- Little work during last 2 years [as of 1905]. Country rock is greenstone and greenstone schist with some intercalated slate. Where mineralized, greenstone schist is altered to talc schist.

Wright, 1907 (B 314), p. 53-54 -- Energetic development in 1906. More than $1,000 \mathrm{Et}$. Of underground workings and a $20-5$ tamp mill, ore is in narrow bands and consists essentially of quartz and calcite veinlets, auriferous pyrite, and sulfides of copper, lead, and zinc.

Knopf, 1910 ( 8442 ), p. 135 -- Tunnel being ariven to undercut ore body. Reference to Spencer, 1906 (B 287), p. 92.

Knope, 1911 ( 8 480), p. $96--3,100 \mathrm{ft}$. of projected 3,500-ft. tunnel completed, 1910 .

Brooks, I91.2 (B 520), p. 25 - Crosiscut extended to. 3,400 ft. ; some ore bodies said to have been found, 1911.

Eakin, 1915 (B 622), p. 96-98 -- Three men driving prospecting tunnels, 1914. Country rock is schistose greenstone showing considerable alteration and minexalization over an area $1 \mathrm{mi}$. wide and $1-1 / 2 \mathrm{mi}$. long. zone averaging $90 \mathrm{ft}$. wide and traceable for $2,000 \mathrm{ft}$. on surface said to consist largely of commercial ores. Total of $3,650 \mathrm{Et}$. of development work has been done: $365 \mathrm{ft}$. is in ore.

Chapin, 1916 (B 642), p. 75 - Company reorganized, 1915; some development work. 
Alaska Treasure (Gold Mining Co.) - - Continued

Smith, 1917 (BMB 142), P. 35 -- Crosscut has been driven to mineralized zone; unl11 near beach; 1915 .

Smith, 1917 (BMB 153), p. 22 -- Assessment work, 1916.

Smith, 1937 (B 880-A), P. 17 -- Sampling of deposit, 1935.

Brew and Ford, 1969 (OF 361), table 2, samples 58-63 -- Samples contained pyrite, galena, chalcopyrite, pyrrhotite, and tetrahedrite(?) in quartz vein and phyllite. 

Alaska-Washingtón (Gold Mining Co.) Gola, Zinc
Juneau district
Juneau $(10.5,10.3)$
$M F-435$, loc. 23
$58^{\circ} 35^{\prime} \mathrm{N}, 134^{\circ} 51^{\prime} \mathrm{W}$

Summary: Quartz fissure vein in greenstone conglomerate contains much auriferous pyrite ana a little sphalerite. Several hundred feet of underground workings driven in early 1900's. No record of production.

Wright and Wright, 1905 (B 259), P- 54 -- Several hundred feet of tunneling and a 50-ft. shaft completed in 1904.

Spencer, 1906 (B 287), p. 133 - Similar to Bessie vein; fissure appears to be continuous for nearly $3,000 \mathrm{ft}$; in andesite breccla. Developed by $600 \mathrm{ft}$. of drifting on 3 levels. Values as high as $\$ 8$ have been reported.

Wright and Wright, 1906 (B 284), p. 35 -- 2 parallel veins separated by $600 \mathrm{ft}$. of slate and greenstone. Mine workings (all on one vein) were completed in 2902 and consist of $500 \mathrm{Et}$. of tunneling, a 70-ft. raise, and a $30 \mathrm{mt}$. shaft.

Knopf, 1912 (B 502), p. 48-49 -- Vertlcal quartz vein (average thickness 3 Et., maximum thickness $6 \mathrm{ft.l}$ cuts across greenstone conglomerate. quartz sheared and brecciated; contains much coarsely crystalline pyrite and a little sphalexite; considerable fine gold where pyrite is oxidized. Gold appears to be limited to short shoots. Workings consist of $500 \mathrm{ft}$. of drifts, 70-foot raise, and 30-ft. shaft. A little work in 1910 after long period of idleness.

Berg and Cobb, 1967 (B 1246), p. 158-159 -- Has been underground exploration. 
Juneau district'

Juneau $(15.7,5.1)$

MF- 435 , loc. 54

$58^{\circ} 17^{\prime} \mathrm{N}, 134^{\circ} 18^{\prime} \mathrm{W}$

Sumary: Quartz veins and stringex leads in black slate contain pyrite, sphalerite, and galena. Next to Silver Queen mine; gold and silver undoubtedly present, but no data on tenor.

Spencer, 1906 (B 287), p. 55 -- In Sheep Cx. basin adjolning Silver queen. Black slate above greenstone footwall cut by quaxtz veins 2-4 ft. thick and stringer leads of small quartz masses separated by slate. Tunnels 40-50 ft. long ariven on 2 veins. Metallic minerals present are pyrite, sphalexite, and galena. [No data on gold content.] 
(Auk Bay)

Juneau district
$\operatorname{Gold}(?)$

Juneau $(12.5-12.6,6.7-7.15)$ ápprox. $58^{\circ} 23^{\prime}-58^{\circ} 24^{\prime} N, 134^{\circ} 38^{\prime} \mathrm{W}$ approx.

Sumnary: Development reported in 1913 and 1915. May refer to work at Dull \& Stephens, Treasury Hill, or Winn. See also: Dull \& Stephens, Treasury Hill, winn.

Brooks, 1914 (B 592), p. 59 -- "Some developments were also made on the Peterson and Auk Bay properties." Reported in 1913.

Chapin, 1916 (B 642), p. 78 -- Considerable prospecting and some development work, 1915.

Martin, 1920 (8 712), p. 30 -- Did not operate in 1918. 
Aurora Borealis

Juneau district

Mr $-435,10 c, 22$
Gold, Lead

Juneau $(10.4,10.4)$

$58^{\circ} 36^{\prime} \mathrm{N}, 134^{\circ} 52^{\prime} \mathrm{W}$

Sumary: Quartz vein as much as 3-1/2 Et. thick in black slate near contact with greenstone worked by two 200-ft. tunnels; contains gold, arsenopyrite, pyrite, and subordinate galena. Had small mill. Production, all before 1895, was about 266 fine oz. of gold. Includes references to $\mathrm{AB}$ and Morningstar,

Wright and Wright, 1906 (B 284), p. 35 - quartz ore body is parallel to a contact between black slate and greenstone. Opened by 3 tunnels each of which is a few hundred feet long. Ore treated in 5-stamp mill. Pyoduction reported to have been about $\$ 25,000$ (about 1,210 fine oz, ] in gold. Shut down several years before 1905.

Knopf, 1912 (B 502), p. 47-48 -- Quartz vein as much as $3-1 / 2$ ft. thick strikes $\mathrm{NE}$ and dips $27^{\circ} \mathrm{NW}$; ribbon structure parallel to walls; in black slate country rock. Vein contains arsenopyrite, pyrite, and subordinate galena. Greenstone and associated clastic rocks encountered in upper of 2 tunnels, each of which is slightly more than $200 \mathrm{ft}$. long. Mill operated for a short time before 1895, production said to have been $\$ 5,500$ [about 266 fine oz.] in gold.

Chapin, 1916 (B 642), P. 77 -- Claims relocated and "moderate" development, 1915.

Berg and Cobb, 1967 (B 1246), p, 158-159 -- Quartz vein worked by two 200-ft. tunnels; yielded about 260 oz. of gold, all before 1895. 
Juneau district

Juneau $(8.3,15.2)$

MF-435, loc. 14

$58^{\circ} 52^{\prime} \mathrm{N}, 135^{\circ} 05^{\prime} \mathrm{W}$

Summary: Two quartz veins as much as $5 \mathrm{ft}$. wide were mined in 1895-97 from drifts and stopes from a tunnel l, $100 \mathrm{ft}$. long that crosscuts velins. Vein contains small amounts of pyrite and chalcopyrite. Total amount of ore mined was about 5,500 tons, mainly from Bear vein.

Becker, 1898, p. 62-63 -- Minerals present include calcite, chalcopyrite, and mispickel.

p. 76 -- Country rock is diorite; Bear vein is 2-1/2 to $11 \mathrm{ft}$. wide; contains quartz, calcite, sericite, pyrite, chalcopyrite, arsenopyrite, and fragments of country rock. Developed by 3 short tunnels; no production.

Wright and Wright, 1906 (B 284), p. 32 -- Tunnel l,100 ft. long intersects 2 quartz veins along which drifts were run for several hunared feet. 5,500 tons of quartz ore mined, 1895-97, ore much lower than that from comet mine; only 628 of gold was recovered in bullion.

Knopf, 1911 (B 446), p. 39-40 - Country rock is greenish (from chlorite and epidote) diorite. Tunnel 1,100 ft. long cuts Bear vein $500 \mathrm{ft}$. from portal and $200 \mathrm{ft}$. below surface. About 5,500 tons of ore removed stopes on 3 levels, 1895-97. Bear vein is $2 \mathrm{ft}$. wide at surface and $5 \mathrm{ft}$. wide at adit level; very few metallic minerals (pyrite and chalcopyritel in vein; small pyrite cubes and quartz stringers in highly altered wall rock. Smaller vein encountered $300 \mathrm{ft}$. from portal; about $100 \mathrm{ft}$. of drifts on it.

Chapin, 1916 (B 442), p. 77 -- Property consolidated with Kensington and comet in 1915 .

Berg and Cobb, 1967 (B 1246), p. 160 -- Has been production from mine. 
(Bear Cr.)

Admiralty district
Asbestos

Juneau $(11.0,4.6)$

$58^{\circ} 15^{\prime} \mathrm{N}, 134^{\circ} 47^{\prime} \mathrm{W}$

Sumary: Prospecting of an occurrence of tremolite asbestos in amphibole schist in 1928 and possibly 1929. Brittle fibers that do not separate well are 18 in. long; material is weathered, so possibly fresh material would be better grade. A few veins of cross-fiber asbestos in veins $3 / 4$ in. wide and $6-8$ in. long may be of better quality.

Smith, 1930 (B 813), p. 71-72 -- Chrysotile asbestos in fibers some of which are nearly a foot long. Fibers are brittle and weak; may be badly weathered. Some work (largely construction of houses and roads), 1928.

Silth, 1932 (B 824), P. 80 -- tas been considerable prospecting, 1929. other data same as above.

Snith, 1933 (B 836), P. $82--$ No work, 1930.

Smith, 1933 (B 844-A), p. 81 -- No work, 1931.

Twenhofel and others, 1949 (B 963-A), P. 34-37 -- Tremolite (not chrysotile as reported earlier) in fibers as much as 18 in. long parallel to serike of the 18-in. -wide band of asbestos in amphibole schist. Material does not separate into fibers and breaks easily; weathered, so possibly fresh material would be better grade. Also a few small veins of cross-fiber asbestos that appears to be of better quality; velus $3 / 4 \mathrm{in}$. wide and $6-8 \mathrm{in}$. long.

Lathram and others, 1960 (I-323) -- Asbestos prospect.

Race and Rose, 1967 (GC 8), p. 19 -m Tremolite asbestos $1-1 / 2$ ft. wide exposed for $14 \mathrm{ft}$; in schist; development was some trenching. 
Bear's vest

Juneau district
Gold (?)

Juneau

SE $1 / 4$ quad.

Summary: Prospecting reported, 1911. On Douglas I.

Brooks, 1912 (B 520), p. 25 -- prospecting reported, 1911. On Douglas I. 
(Berg Mtn.)

Juneau district

$\mathrm{MF}-435$, loc, 1
RE

$$
\text { Juneau }(2,75,16,8)
$$$$
58^{\circ} 57^{\circ} \mathrm{N}, 235^{\circ} 42+\mathrm{W}
$$

Summary; Trace of yttrium in pyritic siliceous rock,

Lathram and others, $1959(I-303)$, sample $22-\pi$ Disseminated pyrite in ironstained siliceous rocks. Keavy-mineral concentrate contains trace of yttrium.

Berg and Cobb, 1967 (B 1246), p. 162 -m Traces of yttrium in pyritic siliceous rock. 
Berners Bay

Juneau district
Gold (?)

Juneau $(9.8,12.8)$ approx. $58^{\circ} 44^{\prime} \mathrm{N}, 134^{\circ} 56^{\prime} \mathrm{W}$ approx.

Summary: Claim on which prospecting was reported in 1905.

Wright and Wright, 1906 (B 284), p. 34 Clain on south side of Berners Bay. Prospecting reported in 1905, 
Juneau district

Juneau $(10.4,10.4)$

MF-435, loc. 22

$$
58^{\circ} 36^{\prime} \mathrm{N}, 134^{\circ} 52^{\prime} \mathrm{W}
$$

Summary: Vertical sheeted quartz vein 1-5 ft. thick cuts across greenstone conglomerate; contains arsenopyrite, pyrite, sphalerite, galena, and free gold. Traced for about l, $600 \mathrm{ft}$. and opened by about $645 \mathrm{ft}$. of underground workings in early 1900's. A few tons of ore was shipped for testing; no record of commercial production.

Spencer, 1906 (B 287), p. 133 -- Vein crosses bedding of andesitic tuff or greenstone country rock; traced for about 1,600 ft.; from about a fogt to 5 or $6 \mathrm{ft}$. thick; average about $3 \mathrm{ft}$. Principal sulfide is arsenopyrite, with some pyrite and free gold. Not much development in 1903.

Wright and Wright, 1906 (B 284), p. 35 -- Data about the same as above.

By 1905 there were tunnels 360 and $124 \mathrm{ft}$. long and a shaft $161 \mathrm{ft}$. deep. A few tons of ore was shipped for testing. Property idle for 2 years.

Knopf, 1912 (B 502), p. 48 -- Vertical sheeted quartz vein 1-5 Et, thick cuts across greenstone conglomerate; contains small amounts of pyrite and arsenopyrite and rare galena and sphalerite. Vein intersected by workings about $1,200 \mathrm{ft}$. apart along strike. Workings consist of 2 tunnels and a shaft.

Berg and Cobb, 1967 (B 1246), p. 158-159 -- has been underground exploration. 
Black Chief

Juneau district

MF- $435,10 c .26$
Gold, Lead

Juneau $(11.0,10.5)$

$58^{\circ} 36^{\prime} \mathrm{N}, 134^{\circ} 48^{\prime} \mathrm{W}$

Summary: Quartz stringers in crushed black slate in a zone 4-20 ft. wide contain a little pyrite and galena, $180 \mathrm{ft}$. (Knopf) or $312 \mathrm{ft.}$ (Wright) of underground development by 1909. Gold content of ore not given, but there must be some or there would have been much less development.

Wright, 1908 (B 345), p. 89 -- Vein deposits being explored, 1907. Wright, 1909 (B 379), p. 71 -- By 1908 three veins had been explored by drifts from 2 crosscuts and a surface excavation; underground workings had total length of about $312 \mathrm{ft}$.

Knopf, 1912 (B 502), p. 51 - Lode consists of narrow quartz stringers in "thoroughly smashed" black slate; width of lode is indefinite and ranges fxom 4 to $20 \mathrm{ft}$. guartz contains a little pyrite and galena. Lode is undercut by tunnel about $180 \mathrm{ft}$. long. 
Blue Jay (near Eagle R.)

Juneau district

MF-435, 10C. 25
Gola

Juneau $(10.8,10.75)$

$58^{\circ} 36^{\prime} \mathrm{N}, 134^{\circ} 49^{\prime} \mathrm{W}$

Sumaxy: In 1907 a 25-ft. drift was driven on a quartz-slate stringer lode; similar to Joyce-Jensen, which carries about $1 / 3$ oz. Of gold per ton.

Wright, 1908 (B 345), p. 89 -- 25-foot drift on vein deposit, 1907. Knopt, 1912 (B 502), p. 51 -- Quartz-slate stringer lode; similar to Joyce-Jensen, which carries as much as $\$ 7$ a ton in gold. 
Sumury: Mineralized albite diorite dike $50 \mathrm{ft}$. (Wright) or $100 \mathrm{ft}$. (Knopf) thick constitutes very low-grade gold ore. Development in 190506 consisted of shaft $118 \mathrm{ft}$. deep and $500 \mathrm{ft}$. of drifts and crosscuts. More work reported in 19l4. No record of production.

Wright and Wright, 1906 (B 284), p. 38 -- Development, summer of 1905. Wright, 1907 (B 314), p. 55 - Mineralized dike $50 \mathrm{ft}$. wide is a very lowgrade ore. Development [as of 1906] consists of shaft $118 \mathrm{ft}$. deep and $500 \mathrm{ft}$. of drifts and crosscuts.

Kropf, 1912 (B 502), p. 27-28 -- Albite diorite dike $100 \mathrm{ft}$. thick; accessory minerals are apatite, titanite, and magnetite.

p. 59 - Albite diorite dike.

Eakin, 1915 (B 622), P. 102 -- Some work done, 1914. 
Bull Consolidated

Juneau district

MP $-435,10 c .51$
Gold

Juneau $(15.6,5.45)$ approx.

$58^{\circ} 18^{\prime} \mathrm{N}, 134^{\circ} 19^{\prime} \mathrm{W}$ approx.

Summary: Small ledge of rich ore at head of Gold Cr. staked in 1905.

Wright and wright, 1906 (B 284), p. 38 - Small ledge of rich ore at head of cold Cr. staked in 1905. A few sacks of ore removed for testing, but no other development. 
California (near Eagle R.)

Juneau district

MF-435, 100. 21
Gold, Lead

Juneau $(10.15,11.7)$

$58^{\circ} 40^{\prime} \mathrm{N}, 134^{\circ} 53^{\prime} \mathrm{W}$

Summary: Mineralized schist and slate along contacts with greenstone.

ore body contains quartz, carbonates, arsenopyrite, galena, and (presumably) gold, Minor underground exploration in late $2990^{\prime} \mathrm{s}$ and/or early 1900 's.

Wright and Wright, 1906 (B 284), p. 34 -- Assessment work with encouraging results, 1905.

Knopf, 1912 (B 502), p. 46-47 - Located in 1897. Country rock is slate,. green schists, greenstone, and breccia. Oxe body is 3-ft.-thick. zone of green schist at contact with greenstore hanging wall irregularly traversed by veinlets of quartz and carbonates carrying arsenopyrite and a little galena. Another lode is in slate along contact with greenstone footwall. Lodes Eollowed by tunnels, longer of which is $160 \mathrm{ft}$. long. 
Cascade

Juneau district

MF-435, 10c. 27
Gold, Lead, Zinc

Jureau $(10.95,10.35)$

$58^{\circ} 35^{\prime} \mathrm{N}, 134^{\circ} 48^{\prime} \mathrm{W}$

Summary: Quartz stringer lode in slate is 6 ft. thlck and contains arsenopyrite, galena, and sphalerite. Gold content over width of $5 \mathrm{ft}$. said to average $\$ 12$ a ton (about $0.58 \mathrm{oz}$. per ton). Open to a depth of $90 \mathrm{ft}$. by inclined snaft. All work in early $1900^{\prime} \mathrm{s}$.

Wright and Wright, 1906 (8 284), p. 34-35 -- 6-ft. quartz vein in graphitic slate and schist one mile east of intrusive rocks.

Wright, 1907 (B 314), p. 57 -- Tunnel being driven to undercut lode, 1906, Wright, 1908 (B 345), p. 89 -- 6-ft. quartz vein; 2 prospect shafts and open cuts.

Knopf, 1912 (B 502), p. 50 -- 6-ft. stringer lode in slates - Quartz stringers contair arsenopyrite, galena, and sphalerite; ore said to average $\$ 12$ over a width of $5 \mathrm{ft}$. Inclined shaft reaches depth of $90 \mathrm{ft}$. 
clark (Carlson cr.l

Juneau district

MF-435, loc. 52
Antimony, Gold, Lead, Silver, Zinc

Juneau $(15.95,5.95)$ approx. $58^{\circ} 20^{\prime} \mathrm{N}, 134^{\circ} 16^{\prime} \mathrm{W}$ approx.

Summary: quartz veins in schist and pegmatitic injection gneiss contain sparse sulfides, including pyrite, stibnite in radiating needles or blades, azsenopyrite, sphrlerite, and galena. Samples (probably not representative) contained as much as $1.03 \mathrm{oz}$. gold and $4.25 \mathrm{oz}$. silver a ton. Explored by surface stripping of overburden and tunnel $150 \mathrm{ft}$. long. Includes reference to (Sunset Cove).

Buddington, 1926 (B 783), P. 50-52 - staked in 1911; 6 claims. Quartz veins fill highly brecciated zones in mainly schist and pegmatitic injection greiss with rare sheets of quartz diorite and sparse basalt dikes that appear to be younger than the veins. Exploration has been by strippling off overburden and driving a tunnel $150 \mathrm{ft}$. long. Sulfides are generally sparse, include pyrite, stibnite, arsenopyrite, sphalerite, and galena. Samples [probably not representative] contained from 0.12 to $1.03 \mathrm{oz}$. gold per ton. One sample of vein material with stibnite contained $4.25 \mathrm{oz}$. silver and $\$ 2.80$ [about $0.135 \mathrm{oz}$. ] gold per ton.

Buddington and Chapin, 1929 (B 800), p. 331 -- Stibnite in radiating needles or blades in lowngrade gold quartz fissure veins in schist.

p. $363-m$ Considerable stibnite in veins; unusual association.

Smith, 1934 (B 857-A), p. 15 - Prospecting, 1932.

Kaufman, 1958 (IC 7844), P. 9-. Native antimony in gold quartz vein at Sunset cove.

Berg and Cobb, 1967 (B 1246), p. 155 - quartz veins with inclusions of silicified country rock in schist and pegmatite injection gneiss contain minor amounts of pyrite, stibnite, arsenopyrite, sphalerite, and galena. Explored by a 150-ft. tunmel and geveral trenches. samples taken by owner contained 0.12 to $1.03 \mathrm{oz}$. gold per ton. 
Clark (Lemon Cr.)

Juneau district

$\mathrm{MF}-435,100.43$
Copper, Gold

Juneau (14.45, 6.65)

$58^{\circ} 22^{\prime} \mathrm{N}, 134^{\circ} 26^{\prime} \mathrm{W}$

Sumary: Quartz vein in slate and/or altered gabbro contains pyrrhotite and a little chalcopyrite; gold content no more than about 0.05 oz. per ton.

Spencer, 1906 (B 287), p. 118 - Country rock is black slate cut by diorite (altered gabbro) dikes. quartz veins as much as $3-4$ ft. thick contain pyrrhotite and a little chalcopyrite; highest gold assays no more than $\$ 1$ a ton. Vein where the must work was done was exposed. more than $200 \mathrm{ft}$. horizontally and for a height of about $100 \mathrm{ft}$. 
Comet

Juneau district

MF $-435,10 c .16$
Copper, Gold, Lead

Juneau $(8.45,15.0)$

$58^{\circ} 51^{\prime} \mathrm{N}, 135^{\circ} 04^{\prime} \mathrm{W}$

Summary: Quartz fissure veins in diorite near (but almost normal to) contact with slate and graywacke. Main vein 2-8 ft. thick with horses of diorite; values pockety. Veins contained pyrite, chalcopyrite, galena, and free gold; most of gold free. Deposit located in 1900. Mine operated, 1894-1901; recorded production (probably was considerably more) was about 22,250 fine oz. of gold from about 50,000 tons of ore. More than a mile of workings. Surface work in $1930^{\prime} \mathrm{s}$ did not "result in reopening mine.

Becker, 1898, p. 62-63 -- Minerals present include calcite and chalcopyrite. p. 76-77 - Several veins in diorite; developed by 3 small tunnels and a winze about $100 \mathrm{ft}$. deep. Comet vein is as much as $8 \mathrm{ft}$. thick (average $3 \mathrm{ft.l}$; consists of quartz, pyrite, chalcopyrite, and galena; in places there is much free gold with few sulfides. Production, July 1894-June 1895 was more than $\$ 200,000$ [about 9,675 fine 0z.] in gold; ore averaged $\$ 50-\$ 60$ a ton. Only about 1 of ore is sulfides, whlch run about $\$ 160$ a ton. Production in 1896 was about $\$ 125,000$ [about 6,050 fine oz.] in gold. Other smaller veins on property. Spencer, 1904 (B 225), o. 38 -- Deposit in veins in fissures in diorite. Spencer, 1906 (B 287), P. 136-137 -- Principal producing mine in Sherman Creek arainage; several thousand feet of underground workings. Welldefined ore shoot lying diagonally in vein was mined to depth of about l, $000 \mathrm{ft.;}$ much of gold "in nests or bonanzas."

Wright and Wright, 1906 (B 284), p. 32 -- Mine operated, 1894-1901. Quartzfilled fissure 2-8 $\mathrm{ft}$. thick that incorporates country rock and therefore becomes lower grade at depth. Vein faulted off at north end; may continue as Northern Bell vein. Production was more than 50,000 tons of ore, which yielded about $\$ 460,000$ [about 22,250 fine oz.] in gold. Main level is crosscut $1,875 \mathrm{ft}$. long, vein mined out above it.

Knope, 1911 (B 446), P. 42-43 -- Located in 1890. Main crosscut begun in 1896, Operated until 1901, when it was tied up in litigation. Two veins in diortte near, but nearly normal to, contact with slates and graywackes of Berners Fm. Larger vein is a well-defined fissure vein 2-8 ft. thick; horses of diorite; values pockety; some pockets contained $\$ 50,000$ or more in gold. Recorded production (probably was considerably more) was $\$ 460,000$ (about 22,250 fine oz, of golal from 50,000 tons of ore. 87 of value in free gold; 5 in concentrates. Main vein stoped from level 600 tt. below surface to surface, Over a mile of underground workings.

Chapin, 1916 (B 642), p. 77 -- Kensington, Bear, and Cowet properties have been consolidated, 1915.

Buddington and Chapin, 1929 (B 800), p. 317 -- Example of fissure veins. p. 345 -- Some visible gold in quartz in pockets.

Smith, 1934 (B 864-A), P. 17 -- Property examination, 1933.

Smith, 1937 (B 880-A), P. 17 -- Buildings and surface equipment being put in shape, 1935. 
Comet -- Continued

Sujth, 1938 (B 897-A), p. 17 -- Road construction and work on surface plant, 1936.

Smith, 1939 (B 910 A), p. 19 -- Work discontinued, 1937.

5mith, 1942 (B 933-A), P. 17 -- Local reports that mine would be reopened under Canadian management, 1940.

Noel, 1966, p. $60 \cdots$ One of important mines of Berners Bay area.

Berg and Cobb, 1967 (B 2246), p. 160 -- Extensive workings on quartz veins in diorite; averaged less than $1 / 2 \mathrm{oz}$. gold per ton. 
Cottrell-Spaulding

Juneau district

$M F-435,10 c .26$
Gold

Juneau (11.0, 10.5) approx. $58^{\circ} 36^{\prime} \mathrm{N}, 134^{\circ} 48^{\prime} \mathrm{W}$ approx.

Sumary: Vein reported to be exposed for length of $1,500 \mathrm{ft} . ; 2-1 / 2 \mathrm{ft}$. wide; gold values. Crosscut $160 \mathrm{ft}$. driven to undercut vein, 1907. See also E Rluribus Unum; may be the same property.

Wright, 1908 (B 345), p. 89 -- Vein reported to be exposed over a length of $1,500 \mathrm{ft}$. averages $2-1 / 2 \mathrm{ft}$. wide and carries gold values. Crosscut tunnel $160 \mathrm{ft}$. long undercuts vein at depth of $100 \mathrm{ft.}, 1907$. 
Dividend

Juneau district

MF-435, 10c. 27
Gold, Lead

Juneau $\{10.95,10.35\}$

$58^{\circ} 35^{\prime} \mathrm{N}, 134^{\circ} 48^{\prime} \mathrm{W}$

Summary: Black slate with many quartz-calcite stringers carries pyrite, arsenopyrite, galena, and free gold across a thickness of $12 \mathrm{ft}$. above a footwall of greenstone. Workings (mainly an access crosscut) total about 1,300 Et. in length. No record of production.

Wright and Wright, 1906 (B 284), p. 34-35 -- Lade (12 ft. wide) of mineralized black slate cut by quartz stringers.

Wright, 1907 (B 314), p. 57 -- Tunnel being driven to undercut lode, 1906. Wright, 1908 (B 345), p. 89 -- Undercut by tunnel $900 \mathrm{Ft}$. long at depth of $350 \mathrm{ft.;}$ lode said to be more than $60 \mathrm{ft}$. wide at tunnel level and to contain gold values.

Wright, 1909 (B 379), p. 71 -- Crosscut is 1,170 Et. long; intersects lode $900 \mathrm{ft}$. from mouth at depth of $350 \mathrm{ft}$; d drift extended $250 \mathrm{ft}$. along ore body.

Knopi, 1912 (B 502), p. 49-50-- 1,200-ft. tunnel intersects lode 1,000 ft. from portal at depth of $187 \mathrm{ft}$. Footwall of lode is several hundred feet of augite melaphyre [greenstone]; lode is graphitic slate traversed by thin stringers of quartz and minor calcite carrying pyrite, arsenopyrite, galena, and free gold. Lode followed for about $100 \mathrm{ft}$. by a drift. Where exposed on surface lode is $12 \mathrm{ft}$. wide. 
Doran

Juneau district

$M F-435,100.44$
Gold (?)

Juneau $(14.05,6.1)$

$58^{\circ} 20^{\prime} \mathrm{N}, 134^{\circ} 28^{\prime} \mathrm{W}$

Sumary: Shattered, sheared, and altered albite diorite dike is traversed by pyritic quartz-albite-carbonate veinlets. $130 \mathrm{ft}$. of tunnel and drift. No data on precious-metal content, if any.

Knopf, 1912 (B 502), p. 60 -- Shattered, sheared, and altered albite diorite dike "is traversed by pyritic veinlets composed of quartz, albite, and carbonates." [No statement that any valuable mineral is present.] $130 \mathrm{ft}$. of tunnel and drift. 
Douglas Mining Co.

Juneau district

$M F-435,100,60$
Coppex, Gold, Zinc

Juneau (14.55, 5.0)

$58^{\circ} 16^{\prime} \mathrm{N}, 134^{\circ} 25^{\prime} \mathrm{W}$

Sumary: Glassy quartz stringers in altered sheared diorite dike about 70 ft. thick in slate contain considerable calcite and sparsely disseminated chalcopyrite, pyrite, and sphalerite. A tunnel completely crosscuts dike. Diorite in tunnel is reported to contaln $\$ 1.50-\$ 2.00$ a ton in gold (gold at $\$ 20.67$ an ounce) with one zone $3 \mathrm{ft}$, wide containing about $\$ 3.50$ (about $0.17 \mathrm{oz}$. ) gold per ton.

Buddington, 1926 (B 783), P. So -- On Douglas I. Fighly altered sheared diorite dike in black slate being prospected, 1924. Tunnel $120 \mathrm{ft}$, long completely crosscuts diorite, which is about $70 \mathrm{ft}$. thick. Glassy quartz stringers in diorite contain considerable calcite and sparsely disseminated chalcopyrite, pyrite, and sphalerite. Diorite in tunnel reported to have average assay value of $\$ 1.50-\$ 2.00$ a ton; one zone $3 \mathrm{ft}$. wide averages about $\$ 3.50$ [about $0.17 \mathrm{oz}$. gold] per ton. 
Dull \& stephens

Juneau district

MF-435, loc. 40
Gold

Juneau (12.5, 7.15)

$58^{\circ} 24^{\prime} \mathrm{N}, \quad 134^{\circ} 38^{\circ} \mathrm{W}$

Summary: Several ounces of gold was recovered while sluicing glacial till overburden from irregular masses of quartz in altered volcanic breccia. A little pyrite and arsenopyrite in country rock next to quartz masses.

Knopf, 1911 (B 480), p. 97 -- Large body of low-grade quartz stripped of overburden, 1910.

Knopf, 1912 (B 502), P. 58 -- Irregular masses of quartz in altered volcanic breccia exposed by sluicing off 4-8 feet of tili. A little pyrite and arsenopyrite in rock next to quartz. Several ounces of coarse, rusty gold recovered while outcrop was being sluiced off.

Berg and Cobb, 1967 (B 1246), P. 159 -- Several ounces of gold recovered by sluicling weathered part of guartz vein. 
Eagle River (Mining Co.)

Juneau district

$\mathrm{MF}-435$, 10C. 29
Copper, Gold, Lead

Juneau (12.25, 10.05)

$58^{\circ} 34^{\prime} \mathrm{N}, 134^{\circ} 46^{\prime} \mathrm{W}$

Summary: quartz veins in slate (with a Eew thin sheets of mafic intrusive rock) in shattered zones. Ore shoots are 5-15 ft. wide and 25$100 \mathrm{ft}$, long. Sulfides are pyrite, pyrrhotite, arsenopyrite, galena, and chalcopyrite; native copper also present; most of gold free. Ore bodís cut off by faults. Deposit discovered in 1902; mining began in 1903 and continued through 1910; in 1910 more than 30,000 ft. of underground workings. New adit 1,800 ft. long and $700 \mathrm{Et}$. below old workings driven, 1911-12, mining from it, 1911 to about 1916. A little exploration, but no mining, 1933. Total production was probably more than 20,000 ounces of gold. Includes references to Amalga.

Wright and Wright, 1905 (B 259), p. 54 -m Mining, 1904. Ore reported to average $\$ 30$ a ton; ledge $3-6 \mathrm{Et}$. wide; 20-stamp mill operated.

Spencer, 1906 (B 287), p. 130-131 -- Country rock is graphitic slate. Production in 1904 reported to have been $\$ 75,000$ [about 3,625 fine oz.] in gold. Vein as much as $15 \mathrm{ft}$. wide; quartz with pyrite, arsenopyrite, galena, free gold, and native copper. Mill test of $900 \mathrm{lbs}$. of ore returned $\$ 22$ in free gold and $\$ 15$ in sulfides to the ton. In 1905 three ore shoots had been opened; pitch $30^{\circ} \mathrm{NW}$ in plane of the vein.

Wright and Wright, 1906 (B 284), p. 35 -- Ore shoots in bands of much shattered slate and greenstone; average 5-15 ft. wide and 25-100 ft, long. Ore contains Eree gold, pyrite, pyrrhotite, chalcopyrite, and native copper. In 1905 workings consisted of about 4,000 ft. of shafts and drifts; much stoping. 20-stamp mill. Total production through 1905 was estimated at $\$ 250,000$ labout $12,100 \mathrm{fine} 0 z$. I in gold.

Wright, 1907 (B 314), p. 57 -- Continued production, 1906.

Wright, 1908 (B 345), P. 89 -- Mine operated all of 1907. 12,000 ft. of drifts, crosscuts, and raises. Main vein (1-15 ft, wide) offset several hundred feet by a fault.

Wright, 1909 (B 379), p. 70-71 - Ore body located beyond fault zones which offset it. Mining and milling all year, 1908.

kropf, 1910 (B 442), P. 138 -- Mining and milling, 1909.

Knope, 1911 (B 480), p. 97 -- Mining, milling, and exploration, 1910.

Knope, 1911 (B 480), p. 110 -- Mine in operation since 1903; accounted for most of production from Eagle $R$, area, 1910.

Brooks, 1912 (B 520), P. 26 -- Mainly exploration, 1911.

Knopt, 1912 (B 502), p. 44-46 -- Discovered, 1902; development began in 1903. By 1910 about 30,000 feet of drifts and tunnels had been driven. Much distortion of rocks by landsliding and surface creep. Country rock is interbedded clay slate and graywacke slate with a few thin sheets of mafic intrusive rock. High gold values generally accompany large quantities of sulfides, particularly arsenopyrite and galena. In some places honeycombed quartz with no sulfides carries considerable free gold. Some massive pyrrhotite with a little galena also is good gold ore. 
Eagle River (Mining Co.) -- Continued

Brooks, 1913 (B 542), p. 32 -- Work on new adit continued, 1912.

Brooks, 1914 (B 592), p. 59 -- New adit $800 \mathrm{ft}$. below old workings driven $1,900 \mathrm{ft}$. and reported to have intersected ore body, 1913 .

Brooks, 1915 (B 622), P. 41 -- Stamp mill operated for 3 months in 1914.

Eakin, 1915 (8 622), P. 101 - Adit 1,800 ft. long and $700 \mathrm{ft}$. below old working was driven in zone of slate in an attempt to pick up the lode, which was lost several years ago; several chimneys of ore were encountered, one of which may be an extension of the lost lode. Mining and milling on a small scale began in september, 1914.

Chapin, 1916 (B 642), p. 76-77 -- New adit opened several new ore bodies. 2 stopes renoved; mill began running in June. Ore consists of quartz with galena, pyrite, arsenopyrite, and pyrrhotite, 1915.

Smith, 1917 (BMB 142), p. 35 -- 10 adit levels and a 20-stamp mill, 1915.

Smith, 1917 (BM8 153), P. 23 -- Old workings abandoned. All work now on level $600 \mathrm{ft}$. below old adit; more than 2,700 ft. of working; has been some stoping. Data on milling equipment, 1916.

Eaxin, 1918 (B 662), P. 77 -- Assessment work, 1916. Properties on Eagle $R$. and in Yankee Basin were consolidated.

Martin, 1920 (B 712), P. 30 -- Did not operate, 1918.

Smith, 1934 (B 864-A), P. 17 -- Small crew did some exploration and deve1opment, 1933.

Berg and Cobb, 1967 (B 1246), p. 258 - Mine operated intemittently from about 1913 to 1933 ; major mine in area. Production from area was about $23,000 \mathrm{oz}$. of gold. 
Evoner (Gold Mining Co.)

Juneau district

$M F-435,10 c, 48$
Copper, Gold, Lead, Zinc

Juneau $(15.0,5.6)$

$58^{\circ} 19^{\prime} \mathrm{N}, 234^{\circ} 22^{\prime} \mathrm{W}$

Summary: Next property north of Alaska-Juneau on same lode system. Property staked in 1880, mill installed, 1888. Mined until 1907. Production was worth about $\$ 600,000$ (about 29,000 fine oz. of gold). Much large-scale development and exploration undercutting old workings until mine was joined to Alaska-Juneau and operated with it under a royalty agreement beginning in 1925, after which production was considered part of that of Alaska-Juneau. Sulfides in ore included pyrrhotite, galena, sphalerite, pyrite, and chalcopyrite; magnetite also present. Includes references to: Alaska-Ebner, Taku (Mining \& Milling Co.). See also AlaskaJuneau.

Becker, 1898, p. 62-63 -- Minerals present include pyrrhotite, sericite, zincblende; galena not identified. Called Taku in this reference.

p. 73 -- Country rock is dioritic schist intruded into slate; slate horses in the schist. Irregular quartz stringers contain much pyrrhotite, but no other sulfides, Gold is free.

Spencer, 1904 (8 225), p. 29-30 -- Production, 1903.

p. 35 -- In mineralized zone about $800 \mathrm{ft}$. wide in black slate.

Wright and Wright, 1905 (B 259), p. 53 -- Mining, 1904.

Spencer, 1906 (B 287), p. 58 -- Claims staked in October, 1880. Stamp mill installed, 1888.

p. 66-69--Country rock is slate cut by several diorite dikes. Many quartz veins and veinlets, particularly in diorite dikes, Veins not minable by thenselves; are mined with country rock, which is also mineralized. Principal sulfide is pyrrhotite commonly accompanied in country rock by magnetite. Other sulfides are galena, sphalertte, pyrite, and chalcopyrite. Some visible gold in veinlets. Gangue in veins and veinlets is mainly quartz with some calcite and other carbonates, sericite, biotite, and tourmaline. Mined from open pits [glory holes]. 1,500 ft. of tunnels, and numerous stopes. Ore averages not more than $\$ 2.50$ a ton; mining and milling expense is $\$ 1.25-$ $\$ 1.50$ a ton. Production through 1902 was about $\$ 575,000$ [about 27,820 fine oz.l in gold.

Wright and Wright, 1906 (B 284), p. 37 -- Mining, 1905. Total underground working is nearly 4,000 ft. of tunnels and drifts, plus large stopes.

Wright, 1907 (B 314), p. 54 -- Mining, 1906. Wright, 1908 (B 345), p. 87-88 -- Mining, first half of 1907. Wright, 1909 (B 379), p. 70 -- Operations suspended penaing sale of property, 1908.

Knope, 1910 (B 442), p. 135 -- Dead work and sampling, 1909.

Kropf, 1911 (B 480), p. 96 -- Work begun on new mill, 1910.

Brooks, 1912 (B 520), p. 25 -- Work on tunnel, 1911.

Brooks, 1913 (B 542), p. 32 -- Company went into receivership, 1912; new one said to have been organized.

Brooks, 1914 (B 592), p. 59 - glans for reopening mine, 1913. 
Ebner (Gold Miring Co.) -- Continued

Brooks, 1915 (B 622), p. 41 -- Large-scale development, 1914.

Eakin, 1915 (B 622), P. 96, 98 -- Large-scale development, 1914.

p. 100-101 -- About 100 men engaged in exploratory work. Adit driven $3,500 \mathrm{ft}$, undercutting old workings by $430 \mathrm{ft}$.; other crosscuts also driven in 1914.

Chapin, 1916 (B 642), p. 76 -- No productive mining, but some underground development, 1915 .

Smith, 1917 (BMB 142), p. 35 -- Exploration, 1915.

Suith, 1917 (BMB 153), p. 23 -- About 3,500 ft. of drifts, crosscuts and a raise completed in 1916.

Eakin, 1918 (B 662), p. 77 -- Development work, 1916.

Martin, 1919 (B 692), p. 29 -- Development continued, 1917.

Martin, 1920 (B 712), p. 30 -- Development work, 1918.

Mertie, 1921 (B 714), p. 107 -- Development work, 1919.

Brooks, 1922 (B 722), p. 36 -- About 1,000 ft. of drifting and cxosscutting, 1920.

Smith, 1926 (B 783), p. 7 -- Exploration of Alaska-Juneau Gold Mining Co., 1924.

Moffit, 1927 (B 792), p. 9 -- Preparatory work by Alaska-Juneau Gold Mining Co. , 1925.

Twenhofel, 1952 (OF 60), p. 16-17 -- Historica1 data; mine worked by Alaska-Juneau Gold Mining $C o$. as part of Alaska-Juneau under royalty agreement after 1925.

p. 24 -- Data on peculiarities of production statistics.

p. 28 -- Production before mining by Alaska-Juneau was worth $\$ 600,000$. [about 29,000 fine 0z.]

Berg and Cobb, 1967 (B 1246), p. 154 -- Was a producing mine.

Koschmann and Bergendah1, 1968 (P 610), p. 20 -- Important mine in early days of district. 
Echo Cove Mining Co.

Juneau district
Gold

Juneau (10.15, 11.7$)(?)$

$58^{\circ} 40^{\prime} \mathrm{N}, 134^{\circ} 53^{\prime} \mathrm{W}(?)$

Summary: In 1940 it was reported that there was activity (preiliminary surface developments) in reopening deposits on several old lode claims. May well refer to California (near Eagle R.), Gold Standard, or both.

Smith, 1942 (B 933-A), p. 17 -- "In the Eagle River district....activity was reported to have been revived in reopening the deposits on several of the old lode clains that have been taken over by the Echo Cove Mining $C o$. Work there consisted rainly in preliminary surface developments." [Reported as of 1940\}. 
E Pluribus Unum

Juneau district

MF -435 , 10C. 26
Gold, Lead, zinc

Juneau $(11.0,10.5)$

$58^{\circ} 36^{\prime} \mathrm{N}, 334^{\circ} 48^{\prime} \mathrm{W}$

Summary: 20-inch quartz vein in stringex lode $8 \mathrm{ft}$. thick in uineralized vein 35 or rore ft. wide is against a graywacke hanging wall and contains much axsenopyrite, galena, and sphalerite; assays indicate average gold content of between 9.67 and 14.5 fine oz. per ton; this rich shoot is $18 \mathrm{ft}$. long- Prospect developed by 250-ft. tunnel and $80 \mathrm{ft}$. of raises. See also cottrellSpaulding.

Knopf, 1910 (日 442), P. 138-- Development, 1909. Rich ore shoot oxposed at surface.

Knopf, 1912 (8 502), p. 50-51-- 250 ft. tunnel and $80 \mathrm{ft}$. of raises by 1904. Stringer lode $8 \mathrm{ft}$. thick is part of a minerallzed zone 35 ox more feet wide. 20-1nch quartz vein against graywacke hanging waIl is well mineralized with arsenopyrite, galena, and sphalerite. Assays of this part of the ore body average $\$ 200-\$ 300[9.67-14.5$ fine oz.] in gold per ton. This rich shoot is 18 ft. long. 
Falis

Juneau district

MP-435, 10C. 20 $\operatorname{cold}(?)$

Juneau $(8.75,14.6)$ approx. $58^{\circ} 50^{\prime} \mathrm{N}, 132^{\circ} 02^{\prime} \mathrm{W}$ approx.

Summary: Group of claims near Jualin mine; some prospecting or development in or before 1905. See also Frerming.

Wxight and Wright, 1906 (B 284), p. 34-- Near Freming on Johnson C. . below Jualin mine. Had been worked as of 1905. 
Juneau district

Juneau $(8.75,14.6)$ approx.

MF-435, 10c. 20

$58^{\circ} 50^{\prime} \mathrm{N}, 135^{\circ} 02^{\prime} \mathrm{W}$ approx.

Summary: Partly replaced schist and quartz-calcite stringers in a zone about $6 \mathrm{ft}$. wide in underground workings (total

length about $350 \mathrm{ft} .1$ contain pyrite, chalcopyrite, galena, sphalerite, and Eree gold. No record of production.

Wright and Wright, 1906 (B 284), p. 34-- On Johnson Cr. below Jualin mine.

Knopf, 1911 (B 446), p. 47-- Contact between diorite and green schist; small diorite dikes penetrate schist. Both rocks laced with irregular quartz stringers. Development consists of shaft $85 \mathrm{ft}$. deep, crosscut $360 \mathrm{ft}$. long, and a short drift connecting them. zone of partly replaced schist and quartz and calcite stringers about $6 \mathrm{ft}$. wide contain pyrite, chalcopyrite, galena, sphalerite, and free gold. Not enough data to determine if there is a minable body of ore, but some material is specimen ore. 
(Gold Cx.)

Juneau district

MF-435, Locs. 79-81
Gold

Juneau $(14.75-15.3,5.5-5.65)$

$58^{\circ} 18^{\prime}-58^{\circ} 19^{\prime} \mathrm{N}, 134^{\circ} 20^{\prime}-134^{\circ} 22^{\prime} \mathrm{W}$

Summary: Placers in basin were residual on lodes, eluvial (moved a short distance, mainly by gravity), and stream placers in bedrock basins. Basins (mainly Silverbow Basin at head of creek) mined by draining them through tunnels driven in bedrock and sluicing gravel through siuice boxes in tunnels. Gold discovered in 1880; placer mining on a large scale to 1902 or 1903 and intermittently until 1940. Total production was worth about $\$ 1,308,000$ (about 63,280 fine oz.). Includes references to: Jualpa Mining Co., (Last Chance Basin), (Eittle Basin), (Middle Flat), Nowell, (Silverbow Basin), Silver Bow (Kydraulic) Mines Co.

Becker, 1898, p. 71-72 -- Postglacial lake beds in Silverbow Basin carry gold: section above schist bedrock is a few inches of fine muddy sand, several inches of vegetable material, a layer of large boulders mixed with poorly rounded or angular gravel and muddy sand, and in some plsces a surficlal peaty layer; total thickness is about $50 \mathrm{ft}$. Many pebbles are of gold-bearing quartz. Basin drained for mining by a tunnel 3,500 ft. long in bedrock; production before 1895 reported as no less than $\$ 250,000$ [about 12,100 fine $0 z$. ] in gold. Some of gold probably derived from patches of saprolite on unglaciated areas of bedrock near basin.

Brooks, 1904 (B 225), p. 46 -- No placer mining in silver Bow basin in 1903; development at Last Chance basin.

Spencer, 1904 (B 225), p. 28 - Placer gold discovered, 1880.

p. 34-35 -- Placer gold derived from lodes in basin.

Brooks, 1905 (B 259), p. 31 -- Mining, 1904; also flume construction.

Purington, 1905 (B 263), p. 142-143 -- Details of construction, maintenance, and use of sluice boxes in tunnel in bedrock.

p. 207 - Gold worth $\$ 17.50$ an ounce.

Wright and Wright, 1905 (B 259), p. 37,53 -- Oniy work in 1904 was flume and tunnel construction. Has been profitable mining.

Spencer, 1906 (B 287), p. 2-3 -- Placer gold discovered, August 1880. Low-grade gravels of Silver Bow Basin mined 1891-1902; production estimated at $\$ 416,000$ [about 20,125 fine $0 z .1$; elsewhere on Gold Ex. probably another $\$ 84,000$ [about 4,060 fine 0z.].

p. 57-60 - Summary of early history. Silver Bow Basin mined by means of a tunnel $3,400 \mathrm{ft}$. Iong with sluices in it; gravel hydraulicked, 1891-1901. Total placer production (through 1903?] estimated at $\$ 1,250,000$ [about 60,475 fine $0 z$. ]. [This total is very different from that on $\mathrm{p}$. 3; data for Nowell placer are close, but those for other placers are very different; probably a decimal was misplaced in deriving the data on p. 3 and the figure from p. 60 is more nearly correct.] 
scold $C x$.$) continued$

p. 77-85 - Placers include "hill placers" nearly in place, but somewhat concentrated by slope wash; "gulch placers" formed by concentration of hill placers, and normal stream placers made up of material from gulch placers diluted by barren matorial from gulches not draining areas with lode deposits. Creek placers are gravel deposits in glacially scoured basins; only one mined on a large scale (Nowell cut in Silvex Bow Basin) ran about i4 cents a cublc yard. Hill and gulch placers exhausted by 1890 , production was estimated at $\$ 600,000-\$ 800,000$ in gold.

Wright and Wright, 1906 (B 284), p. 38 -- Mining in Silver Bow Basin and dead work down stream, 1905.

Wright, 1907 (B 314), p. 51 -- Placer mining in Silverbow Basin, 1906.

p. 55 -- Placer mining was in Silverbow Basin; in lower basin Jualpa Mining co. did not mine, 1906.

Wright, 1908 (B 345), p. 88 -- Placer mining in silverbow Basin until August 7, 1907, when a flood filled excavations.

Brooks, 1909 (B 379), p. 51 -- Hydraulicking, 1908.

Brooks, 1910 (B 442), p. 41 -- Placer mining, 1909.

Kropf, 1910 (B 442), p. 135 -- Placer mining in Silverbow Basin, 1909.

Brooks, 1911 (B 480), p. 37 -- A little placer mining, 1910.

Brooks, 1912 (B 520), p. 36 -- Placer mining, 1911, in Silverbow Basin.

Brooks, 1914 (B 592), p. 59 -- Placer operation in upper basin, 1913.

Brooks and Capps, 1924 (B 755), p. 24 -- A little groundsluicing in Silverbow Basin, 1922 .

Brooks, 1925 (B 773), p. 37 -- Placer mining in Silver Bow Basin, 1923.

Moffit, 1927 (B 792), p. 14 -- Placer mining in Silver Bow Basin, 1925.

Smith, 1929 (B 797), p. 16 -- Placer mining in Silver Bow Basin, 1926.

Smith, 1930 (B 810), p. 21 -- Placer mining in Silver Bow Basin, 1927.

Smith, 1942 (B 933-A), g. 32 -- A little hand mining, 1940.

Twenhofel, 1952 (OF 60), p. 4 -- Gold discovered, 1880.

p. 14-16 -- Historical data.

p. 28 -- Placer production from Gold Co. worth $\$ 1,308,000$

[about 63,280 fine oz.].

p. $99--$ Only basin of Gold Co. where gravels could be worked successfully was Silver Bow Basin.

p. 139-140 - Fineness of gold from Silver Bow Basin ranged from 772 to $8273 / 4$ (average $802-1 / 2$ ); gold of local origin.

Kaufman, 1958 (lC 7844), p. 11 -- Placer gold present.

Noel, 1966, p. 53 -- Gold discovered near mouth, 1880.

Cobb, 1973 (B 1374), p. 103 -- Gold discovered near mouth, 1880. Most mining consisted of removing gravel fron bedrock basins through tunnels driven in bedrock. Silverbow and Last Chance Basins accounted for most of the production. 
Golden Treasure

Juneau district
Gold (?)

Juneau (16.0, 4.85) approx. $58^{\circ} 16^{\prime} \mathrm{N}, 134^{\circ} 15^{\prime} \mathrm{W}$ approx.

Sumary: Group of claims in Sheep Creek dralnage. Probably was no production and possibly no work.

Wright and Wright, 1906 (B 284), p. 38 -- Group of claims in sheep Creek drainage. No work in 1905. 
cold king

Juneau district

MF-435, 10c. 17 cold (?)

Juneau (8.6, 15.15) approx.

$58^{\circ} 52^{\prime} \mathrm{N}, 135^{\circ} 03^{\prime} \mathrm{W}$ approx.

Sumary: Group of claims at head of Johnson Cr. near Jualin mine. May have been some work in late 1890's or early 1900's.

Wright and Wright, 1906 (B 284), p. 34 -- Group of claims above Jualin mine at head of Johnson $\mathrm{Cr}$. 
Gold Standard

Juneau district

$M F-435,10 c .21$
Gold, Lead

Juneau $(10.15,11.7)$

$58^{\circ} 40^{\prime} \mathrm{N}, 134^{\circ} 53^{\prime} \mathrm{W}$

Summary: Stringer lode 2-6 ft. thick in slate next to greenstone footwall contains arsenopyrite and rare galena. Samples across $4 \mathrm{l} / 2 \mathrm{ft}$. contalned $\$ 6$ [about 0.3 fine oz.] per ton in gola. Tunnel dxiven $120 \mathrm{ft}$. in early $1900^{\prime} \mathrm{s}$.

Wright and Wright, 1906 (B 284), p. 34 -- Assessment work, 1905. Wright, 1908 (8 345), P. 89 -- Work in 1907; favorable results reported.

Wright, 1909 (B 379), P. 71 -- Exploration, 1908.

Knope, 1912 (B 502), P. 46-47 -- Located, 1896. Stringer lead 2-6 ft. thick in green slate along a greenstone footwall. Sulfides are arsenopyrite (comonly in pieces of slate enclosed in quartz) and rare galena. Samples across a width of $41 / 2 \mathrm{ft}$. reported to average $\$ 6$ a ton in gold. Deposit opened by tunnel $120 \mathrm{ft}$. Long. 
Gould and Curry

Juneau district

MF-435, loc. 55
Copper, Gold, zinc

Juneau $(15.9,5.1)$

$58^{\circ} 17^{\prime} \mathrm{N}, 134^{\circ} 16^{\prime} \mathrm{W}$

Sumary: Crosscut exposed 3 quartz veins about 15 in. thick in a schistose rock, apparently of lgneous origin; contain sphalerite, pyrrhotite, pyrite, and free gold; chalcopyrite reported may not be in the veins. Ore bodies apparently too small for continued profitable mining. Production in 1895 was reported as $\$ 26,000$ [about 1,250 fine oz.] in gold.

Becker, 1898, p. 62-63 -- Minerals present include copper pyrite, pyrrhotite, and zincblende.

p. 73 -- Has been production.

p. 75 -- Schistose rock, apparently of igneous origin; 3 quartz veins about 15 in. wide exposed in crosscut; quartz stringers in schist between veins axe apparently barren. Minerals in veins include sphalerite, pyrrhotite, pyrite, and free gold. production in 1895 reported to have been $\$ 26,000$ (about 1,250 fine oz.] in gold. Spencer, 1906 (B 287), p. 36 -- Spangles of gold in black sphalerite.

p. 49-50 -- Country rock is black slate with diorite (altered gabbro dikes). Discontinuous quartz veins that transgress slaty structure contain pockets rich in free gold; pockets do not appear to contain enough ore for profitable operation. Near prospects are sulfides and quartz veins in a diorite dike.

Wright and Wright, 1906 (B 284), p. 38 -- No groduction or improvements in 1905. 
Greek Bay (Mining Co.)

Juneau district

$M F-435$, loc. 18
Gold

Juneau $(9.15,15.1)$

$58^{\circ} 51^{\circ} \mathrm{N}, 135^{\circ} 00^{\circ} \mathrm{W}$

Summary: Reports on this prospect do not agree. Most recent (Knopf, 1911) states that ore body is a zone of nearly solid quartz veins in a border phase of quartz diorite along contact with altered basalt. other reports call host rock slate along with diorite. Only metallic mineral specifically mentioned is pyrite; there must be some gold or the several hundred feet of underground workings would not have been driven. Last reported activity was assessment work in 1905.

Spencer, 1904 (日 225), p. 38 - stringer lead in slate near contact with diorite.

spencer, 2906 (B 287), p. 236-137 -r In slate; all other mines and prospects in area are in diordte, Vein appears to follow contact between slate and diorite; stringer lead made up of many parallel or branching quartz veins separated by plates of slate. Several hunared feet of drifts on 3 levels connected by a raxse. No mill.

Wright and Wxight, 1.906 (B 284), p. 32 -- In fracture zone along contact between diorite and slate.

p. $34-\cdots$ Ore body is mineralized slate $8-20$ Et. wide cut by quartz stringers, some of which are a few feet wide; Hollows contact between diorite (footwall) and slate. 2 tunnels driven for several hundred feet on one claim. Sulfides [which ones not stated] are irregularly distributed and small in amount. Assessment work only in 1905.

Kropf, 1911 (B 446), p. 47-48 -- ore body follows contact between quartz dioxite gneiss and schistose basalt; nearly vertical stringex lode. Lode is schistose marginal phase of diorite with so many quartz veins that in places it is nearly solid quartz; 4-9 ft. thick; sparse pyrite, Developed by tunnel nearly $700 \mathrm{ft}$. long; last $300 \mathrm{ft}$. an lode. No data on gold content. This description does not match those of Spencer and the Wrights (above).]

Berg and Cobb. 1967 (B 1246), D. 160 -- 700-ft, tunnel that explored sparsely pyritic quartz at sheared contact of quartz diorite and altered basalt. 
Groundhog

Junequ district

MF -435 , 10c. 50
Gold

Juneau $(15.35,5.4)$

$58^{\circ} 15^{\prime} \mathrm{N}, 134^{\circ} 20^{\prime} \mathrm{W}$

Sumary: A few thousand dollars worth of gold mined from tunnels and pits in diorite aikes and greenstone in 1893. Also a little placer mining of broken lode material (hillside placers of Spencer).

Spencer, 1906 (B 287), p. 73-74 -- Claims adjoin Alaska-Juneau and Perseverance. Contact between slate and greenstone crosses claims. Exploration consisted of several tunnels and pits excavated in greenstone and diorite dikes in greenstone in 1893. Production was no more than a few thousand dollars in gold. Has been a little mining of hillside placers [broken lode material essentially in place). 
Juneau district

Juneau $(14.8,5.7)$

MF-435, loc. 47

$58^{\circ} 19^{\prime} \mathrm{N}, 134^{\circ} 24^{\prime} \mathrm{W}$

Summary: Considerable Eree gold in quartz veins in black slate with diorite dikes between greenstone footwall and schist hanging wall. Claims 1ocated in 1901-02; prospecting and sampling until 1909 and in 1931. Probably was no production. Includes reference to Dora. See also Alaska-Juneau, which held option in 1931.

Spencer, 1906 (B 287), 0. 63-66 -- Claims located, 1901-02; prospecting and assessment work, 1903. Black slate (with diorite (altered gabbrol dikes) between greenstone footwall and schist hanging wall contain quartz veins, some with considerable amounts of free gold. Wright and Wright, 1906 (B 284), P. 38 -- Continued development, 1905. Wright, 1909 (B 379), p. 70 -- Surface exploration, 1908.

Knopf, 1910 (B 442), g. 135 -- Dead work and sampling, 1909.

Smith, 1933 (B 844-A), P. 14 -- Alaska Juneau Gold Mining Co. trenched and sampled Hallam and Dora claims during summer of 1931; some underground arifting and crosscutting in fall. (No data on results.) 
Hawk Inlet Mining Co.

Copper, Gold, Lead, Silver, Zine

Admiralty district

Juneau $(10.7-11.4,3.05-4.1)$

Me-435, loc. 69

Summary: Country rock is quartz mica schist and phyllite. Quartz fissure veins traceable for $500 \mathrm{ft}$. or more and as much as 50 ft. wide carry gold, silver, pyrite, galena, sphalerite, and chalcopyrite, Developed by several hundred feet of underground workings and many trenches. Some assays indicated values in gold and silver of $\$ 12$ a ton. Some assays showed more silver than gold and some the reverse. Property active from 1923 to as recently as 1940 with some interruptions. Production was worth more than $\$ 200,000$. Includes references to: Alaska Empire Gola Mining Co., Williams (Mining Co.)

Brooks, 1925 (B 773), P. 12 -- Gold property being developed near small granitic area.

Budaington, 1925 (B 773), P. 72 -- Large, strongly defined quartz veins being prospected, 1923. One workable shoot of low-grade ore has been proved. Southward extension of lodes at Funter Bay.

Buddington, 1926 (B 783), p. 41-44 -- Quartz fissure veins in quartz mica schists and phylikte that in places is isoclinally folded. One vein has been traced for more than 2,000 ft. with a width of 20-50 ft.

p. 47-50 -- 96 claims. Open cuts have been made on each of 10 veins, each of which has been traced for $500 \mathrm{ft}$. or more; large ore shoots of low to mediun grade. One vein has been explored by a tunnel $353 \mathrm{ft}$. long, a winze $48 \mathrm{ft}$. deep, short crosscuts, and open cuts; in graphitic schistose phyllite. Vein contains erratically distributed gold; averages of many samples indicate $\$ 12$ a ton for first $172 \mathrm{Et}$. Of tunnel; a little over $\$ 1$ a ton for last $55 \mathrm{ft}$. of tunnel; more silver than gold in some assays. Some individual assays from this and other veins are much higher in gold. Sulfides in veins include pyrite, galena, sphalerite, and chalcopyrite.

Smith, 1926 (B 783), p. 7 -- Prospecting, 1924.

Smith, 1930 (B 813), P. 14 -- Some development, 1928.

Smith, 1932 (B 824), p. 16 - some development, 1929.

Smith, 1934 (B 864-A), p. 17 -- Development and equipment renovation, 1933. Mill operated less than a month; bullion recovered and concentrates shipped.

Smith, 1936 (B 868-B), p. 16 -- Production work in 1934, New rod mill installed.

Smith, 1937 (B 880-A), p. 16-17 -- Mining, 1935; increase milling capacity. Smith, 1938 (B 897-A), p. 17 - Mining, 1936. Mill not adequate; new equipment ordered.

Smith, 1939 (B 910-A), p. 19 -- Mining, 1937.

Smith, 1939 (B 917-A), p. 19 -- Mining, 1938.

Snith, 1941 (8 962-A), p. 18 -n Mining, 1939.

Smith, 1942 (B 933-A), p. 17 -- Mining on a small scale, 1940.

Lathram and others, 1960 (I-323) -- Map shows symbols for occurrences of of gold, copper, and lead-zinc. 
Hawk Inlet Mining Co, m- Continued

Berg and Cobb, 1967 (B 1246), P. 137 -r Gold discovered before 1900. Produced small amounts of gold for many years.

Race and Rose, 1967 (GC 85, p. 14-15 -m Gold and silver production was worth more than $\$ 200,000$. Fine-grained dikes in some of tunnels and drifts. Float in some of streams is largely "intermediate intrusive rock." Diorite float reported on ridge.

p. 20 -n Gold, pyrite, chalcopyrite, galena, and sphalerite in several large quartz veins in quartz schist. Developed by a shaft, several hundred feet of drift and crosscuts, and trenches. Iotal production over $\$ 200,000$. 
Holland Alaska Gold Co.

Gold

Juneau district

Juneau $(11.3,9,3)(?)$

MF-435, 100. 33 (?)

$58^{\circ} 32^{\prime} \mathrm{N}, 134^{\circ} 46^{\prime} \mathrm{W}(?)$

Sumary: Material shipped in to old Herbert River: mine in 1934: Location given above (from Alaska Territorial Dept. Mines, 12/15/55) may be correct; if so, there are no data on the occurrence. otherwise the reference could be a garbled one to Eagle River or some other mine or prospect in the area.

Smith, 1936 (B 868-A), p. 16 -- In 1934 "in the Herbert River area the Holland-Alaska Gold Co., which is reported to have acquired the old Herbert River mine, shipped in considerable equipment which is to be used in the prospective work on the property." [Complete statement,] Smith, 1937 (B 880-A), p. 17 -- No new developments, 1935.

Smith, 1938 (B 897-A), p. 17 -- No new developments, 1936. 
Holmar

Juneau district
Gola (?)

Juneau SE $1 / 4$ quad.

Sumary: On Douglas I. north of Treadwell. Diamond drilling reported in 1916.

Eakin, 1918 (B 662), p. 77 -- Diamond drilling, 1916. Clain on Douglas I, north of Treadwell. 
Horrible

Juneau district

MF-435, 100. 14 $\operatorname{col} 8$

Juneau $(8.3,15.2)$

$58^{\circ} 52^{\prime} \mathrm{N}, 135^{\circ} 05^{\prime} \mathrm{W}$

Summary: Pyritiferous quartz - Filled fissure vein in fine-grained diorite was mined in 1897-98 and 1901. About 73 fine $0 z$. of gold recovered from 500 tons of ore. Several hundred feet of tunnels and drifts and one or more stopes. Includes references to Portland-Alaska Gold Mining Co.

Spencer, 1906 (B 287), P. 135-136 -- Has been gold production. Has own mi11.

Wright and Wright, 1906 (B 284), P. 33 -- Mine was operated I897-98 and 1901. Quartz vein in diorite. Nearly $1,000 \mathrm{ft}$. of tunneling and orifting; considerable ore was stoped out. Total production reported to have been 500 tons of ore that ylelded about $\$ 1,500$ [about 73 fine oz.] in gold.

Knopf, 1911 ( 8 446), p. 39 -- Claims located in 1896. Mining in 1897 and 1901. Tunnel $400 \mathrm{Ft}$. long on ledge; also a.drift $240 \mathrm{ft}$. Iong that did not encounter an ore body. Ore body mined $(500$ tons of ore that yielded $\$ 1,500$ [about 73 fine oz.] in gold) was a quartz-filled fissure with average thickness of $5 \mathrm{ft}$. in fine-grained green diorite. Only visible metallic mineral sparse pyrite.

Berg and Cobb, 1967 (B 1246), p. 160 - Has been production. 
(Howard Bäy)

Juneau disr.xict

$M-435,10 c .12$
Lead, Silver, Zinc

Juneau $(8.65,5.25)$

$58^{\circ} 18^{\prime} \mathrm{N}, 135^{\circ} 04^{\prime} \mathrm{W}$

Sumary: Discovery of silver-lead ore body carrying some zinc in 1921 wes reported. No other data.

Brooks, 1923 (B 739), p. 21 -- Silver-lead ore body carrying some zinc discovered in 1921. Considerable development work reported.

Berg and Cobb, 1967 (B 1246), P. 162 -- Silver-lead-zine lode reported to have been discovered in 1921. 
Yumboldt

Juneau district

MF-435, 10C. 48
Gold

Juneau $(15.0,5.6)$

$58^{\circ} 19^{\prime} \mathrm{N}, 134^{\circ} 22^{\prime} \mathrm{W}$

Sumary: quartz veins in a mineralized zone in diorite and slate were mined in 1904 and possibly some other years.

Spencer, 1904 (B 225), p. 35 -- In gineralfzed zone about 800 ft. wide in .. black slate.

Wright and Wright, 1905 (B 259), p. 53 -- Mining, 1904.

Spencer, 1906 (B 287), p. 68-69 - Quartz veins in diorite and slate. Wright and Wright, 1906 (B 284), p. 38 -- Development work in 1905. 
Sumary: About 2,800 ft. of tunnels and drifts driven in 1897 and a mill built (but never used). Country rock diorite; sheared to a green schist that was followed by drifts. No ore found in any of workings; quartz stringers near portal of one tunnel carried considerable pyrite and a little chalcopyrite.

Wright and Wright, 1906 (B 284), p. 34 - Claims located in 1896, believed to be an extension of Jualin and comet veins. Country rock is diorite. One tunnel driven 1,100 ft.; $500 \mathrm{ft}$. of drifts near face. Only ore was a narrow belt of quartz stringers carrying chalcopyrite and pyrite about $60 \mathrm{ft}$. from portal. Two other turnels did not find ore. Mill was built, but never used.

Knop , 1911 (B 446), p. 44 -- 3 tunnels aggregating about 2,300 ft. in length and $500 \mathrm{ft}$. of drifts did not find ore. Workings in dioxite, which in drifts is sheared to green schist. Quartz stringers near portal of one tunnel contain considerable pyrite and some chalcopyrite. Mill built, but never used. Most work was in 1897. 
Ivanhoe

Juneau district

$\mathrm{MF}-435,10 \mathrm{c} .13$
Gold

Juneau (8.15, 15.5)

$58^{\circ} 53^{\prime} \mathrm{N}, 135^{\circ} 06^{\prime} \mathrm{W}$

Summary: Only mine or prospect in Berners Bay area not in quartz diorite; in altered basaltic lava flows. By 1903 (after which mine was inactive) 3,000 tons of ore that yielded about $\$ 7,000$ (about 340 fine 02.) in gold was mined from a drift and stope in a quartz vein I-9 ft. (average $5 \mathrm{ft.}$ ) thick. Includes reference to Mellen Mining and Manufacturing co.

Spencer, 1906 (B 287), p. $135-136$ - Has been gold production; has own mil1.

Wright and Wright, 1906 (B 284), p. 33 - Operated at intervals from 1897 to 1903. 4 quartz veins; most of work on one vein where about 1,000 ft. of crosscut and drift were driven. Diorite footwall. Production reportad to have been about $\$ 7,000$ [about 340 fine oz.] in gold from 3,000 tons of ore.

Knopf, 1911 (B 446), P. 38-39 w Vein is 1-9 ft. (average 5 ft.) thick between well-defined wal2s. Country rock is altered basalt or diabase porphyry. Developed by more than 1,000 ft. of tunnel and drift; at one place ore was stoped to surface and 3,000 tons of ore removed; about $\$ 7,000$ [about 340 fine oz.] in gold recovered. Mine had its own mill. Property idle after 1903.

Berg and cobb, 2967 (8 1246), p. 160-- In altered bosaltic lava flows about 3,000 ft. from nearest contact with quartz diorite; only mine in Berners Bay area not in quartz diorite. Before 1903 (when operations ceased) 3,000 tons of ore that yielded about $\$ 7,000$ in gold was mined from a drift and gtope in a quartz vein $1-9$ ft. thick. 
Jersey (City)

Juneau district

MF-435, 100. 61
Gold

Juneau $(14.8,4.8)$

$58^{\circ} 16^{\prime} \mathrm{N}, 134^{\circ} 24^{\prime} \mathrm{W}$

Summary: Prospecting only, 1914 and 1916. Metallic sulfides (no data on what sulfides) locally abundant in interbedded slate and schistose greenstone; encouraging assays reported. No record of mining.

Eakin, 1915 (B 622), p. 98 -- Prospecting (mainly by open cuts), 1914 Bedrock is schistose greenstone interbedded with thin bands of slate. Metallic sulfides (which ones not specified) locally abundant in both greenstone and slate; encouraging assays reported from material encountered in shaft and crosscut driven on one of the richer spots of sulfida mineralization. Geology similar to that at Alaska Treasure rather than that at Alaska Treadwell.

Eakin, 1918 (B 662), P. 77 -- Diamond drilling, 1916. 
Johnson

Juneau district

$M-435,10 c .15$
Gold

Juneau $(8.45,15.2)$

$58^{\circ} 52^{\prime} \mathrm{N}, 135^{\circ} 04^{\prime} \mathrm{W}$

Summary: Stockwork of quertz stringers in shattered country rock along contact between diorite and greenstone; conslderable pyrite. sampling, mainly of material exposed in surface cuts, indicated an ore body 1,500 ft. long, 50-70 Et. wide, and with a minimum average value of $\$ 3.90$ (about $0.189 \mathrm{oz}$. gold) per ton. Reached by kensington cxosscut in about 1913 and explored by $1,600 \mathrm{ft}$. , of drifts and crosscuts. See also Kensington.

Spencer, 1906 (B 287), P. 137 -- Lode along contact between diorlte and greenstone; quartz veins mainly in diorite, with networks of veinlets between sharply defined veins; considerable pyrite.

Wrlgt and Wright, 1906 (B 284), p. 33 -- Development restricted to surface prospecting along a gulch. Mineralization appears to follow contact between diorite and greenstone along which there has been fracturing and faulting.

Knopf, 1911 (B 446), p. 43-44 -- At contact between diorite and now-altered anygdaloids. Ore body is a stockwork of quartz stringers in shattered country rock; heavily impregnated with pyrite; explored by tunnel [divensions not given] and shallow surface cuts. Reported that commercial sampling showed an oxe body $1,500 \mathrm{ft}$. long and 50-70 ft. wide with minimum average value of $\$ 3.90$ a ton.

Brooks, 1914 (B 592), p. 59 -- Kensington tunnel reported to have intersected Johnson lode 4,800 ft. from portal, drifting also reported 1913 . Eakin, 1915 (8 622), p. 101 -- Kensington adit was driven undercut Johnson lode, 1914 .

Chapin. 1916 (B 642), p. 77-78 -- Kensington adit has been driven through Johnson lode, 1915. Johnson lode has been explored by $1,600 \mathrm{ft}$. of drifts and crosscuts.

Eakin, 1918 ( $B$ 662), p. 82-83 -- PIan to mine lode from Kensington crosscut. 
Joyce-Jenson (-Johnson)

Juneau district

MF-435, 10c. 25 $\operatorname{cold}$

Juneau $(10.8,10.75)$

$58^{\circ} 36^{\prime} \mathrm{N}, 134^{\circ} 49^{\prime} \mathrm{W}$

Sumary: Quartz stringer lode in slate is $12 \mathrm{ft}$. thick and is said to contain as much as $\$ 7$ (about 0.34 fine oz.) gold per ton. 40-ft. tunnel ariven on lode before 1910. Includes reference to Yankee Boy.

Wright, 1908 (B 345), p. 89 -- Development reported, 1907.

Knopf, 1912 (B 502), p. 51 -- Tunnel $40 \mathrm{ft}$. long on quartz st.xinger lode in slate. Lode is $12 \mathrm{ft}$. thick, $8 \mathrm{ft}$. of which is said to run $\$ 7$ $a$ ton and the rest between $\$ 1$ and $\$ 2$. Another tunnel was driven $100 \mathrm{ft}$. to undercut lode. 
Jualin

Junear district

MF-435, loc. 19
Copper, Gold, Lead, Zinc

Juneau $(8.7,14.8)$

$58^{\circ} 50^{\prime} \mathrm{N}, 135^{\circ} 03^{\prime} \mathrm{W}$

Sumary: One of principal mines in Berners Bay area, 1896-1901, 1903, 1905-08, and 1915-17. No good data on total production; probably was in the neighborhood of $\$ 1,000,000$ (about 48,375 fine oz.) in gold. Ore bodies were 4 or 5 guartz veins in diorite; one carried about 1 1/2 oz, of gold per ton; the rest had less than $1 / 2 \mathrm{oz}$. gold per ton. In addition to free gold the ore bodies contained considerable pyrite, chalcopyrite, and galena and a little sphalerite and secondary copper minerals. Exclusive of stopes there were more than 18,000 feet of workings. Mine had its own mill, which burned in 1920.

Spencer, 1904 (B 225), p. 38 -- Veins in fissures in diortte.

Wright and Wright, 1905 (B 259), p. 54 - No extensive improvements in 1904. Spencer, 1906 ( 8 287), p. 136 -- Production has been somewhat less than $\$ 500,000^{-}$\{about 24,200 Eine oz. I in gold.

Wright and Wright, 1906 (B 284), p. 33-34 -- Property worked 1896-1900, 1903, and part of 1905. Deposit is 3 ore bodies in diorite $1,200 \mathrm{ft}$. from contact with slate and greenstone. In one vein as much as $5 \mathrm{ft}$. thick free gold is unifomly distributed; also pyrite, chalcopyrite, malachite and azurite. A leaner ore body has an average width of $10 \mathrm{ft}$. for a length of $400 \mathrm{ft}$. The third ore body is $2-6 \mathrm{ft}$. wide and exposed for $150 \mathrm{ft}$. in a drift. Ore is treated in a 10-stamp mill. Wright, 1907 (B 314), p. 57-58 -- Mining and milling, May-October, 1906. Wright, 1908 (B 345), P. 90 -- Mining and milling, 1907. Most of ore above $220 \mathrm{ft}$. level has been stoped out.

Wright, 1909 (B 379), p. 71 - Mining suspended in early summer, 1908. Knope, 1910 (B 442), p. 138 -- Mine idle, 1909.

Knopf, 1911 ( $B$ 446), p. 44-47 - 3 parallel ore bodies of quartz and altered diorite exposed in main adit; middie lode less rich than other two. ore consists of quartz with considerable pyrite, chalcopyrite, and galena ana a little sphalerite, malachite, and azurite, as well as free gold. Most of ore above adit level stoped out; water problems in winzes. Property located in 2896; mined continuously to 1901 and intermittently thereafter. [No data on amount of production].

Brooks, 1912 (B 520), p. 26 -- Plans to reopen mine, 1911.

Brooks, 1913 (B 542), p. 32 -- Development work 1912.

Brooks, 1914 (B 592), p. 59 -- Shaft sinking and surface improvements, 1913.

Brooks, 1915 ( $\mathrm{\theta}$ 622), P. 41 -- Some gold recovered incldental to testing, 1914.

Eakin, 1915 (B 622), p. 101-102 -- Large-scale development until world war I In Europe curtailed operations (Belgian capital was used for development). About 20 men maintaining mine and crosscutting a new ore body, 1914.

Chapin. 1916 (B 642), p. 77 -m Much exploration and some mining and milling, 1915. New ore body opened in 160-ft. level. Working consists of abit level nearly a mile long, an aggregate of 13,000 ft. of workings on 3 other levels, and stopes. 
Jualin -- Continued

Smith, 1917 (BMB 142), p. 35 -- Mine operated, 1915. Average stope width on 3 veins about 5 ft.

Smith, 1917 (BMB 153), P. 23-24 -- Mine operated, 1916. Data on mining and milling methods.

Eakin, 1918 (B 662), p. 77 -- Activity in 1916.

p. 81-82 -- Reference to Knopf, 1911 (B 446), p. 45 - Mining in 1916 consisted of sinking shafts and running drifts in ore, which was enough to keep mill supplied and pay for operation. 2 veins $(7-1 / 2$ $\mathrm{ft}$. and $5 \mathrm{ft}$. thick in developed areas) each have horizontal extent of about $400 \mathrm{ft}$. Workings $310 \mathrm{ft}$, below adit ievel in 1.916 .

Martin, 1919 (B 692), P. 29 -- Operated until october, 1917, when mine shut down because of shortages and high prices of supplies and labor.

Martin, 1920 (B 712), p. 30 - Did not operate, 1918.

Mertie, 1921 (B 714), p. 107-108 -- Considerable exploration and development, but no mining, 1919, 2 more veins have been found since knopf's work in 1909 [Knope, 1911 (B 446), p. 44-47]. Mill practice shows that $80 \%$ gold in quartz veins is free and $20 \%$ in concentrates that are mainly pyrite with some chalcopyrite and galena.

Brookg, 1922 (B 722y, p. 36 -- Work suspended, 1920. Mill burned.

Brooks and Capps, 1924 (B 755), p. 24-25 - New lessee continued old drainage tunnel. Duxing 1915 and 191725,691 tons of ore milled gave average recovery of $\$ 10.81$ a ton; $91 z$ of assay value.

Buddington and Chapin, 1929 (B 800), p. 317 - Example of Eissure veins. Smith, 1930 (B 813), p. 14-15 -- Reports that mine might be reopened, but there was no production in 1928 .

Smith, 1932 (B 824), p. 16 -- Rumors that mine might reopen, 1929.

Berg and Cobb, 1967 (B 1246), p. 159-160 -. Except for one vein that yielded about 1-1/2 oz. gold per ton, ore averaged less than half an ounce of gold per ton. 
Julia

Juneau district

MF-435, loc. 27
Gola (?)

Juneau $(10,95,10,351$

$58^{\circ} 35 \mathrm{kN}, 134^{\circ} 48^{\mathrm{k}}$

Sumary: Stringer lodes of mineralized quartz and slate. Probably conm taln sulfides and gold, but were not developed much, see also cascade.

Wright and wright, 1906 (B 284), p. 34-35 - Group of claims in Yankee Basin; mineralized quartz and schist.

Wright, 1908 (B 345), p. 89 -- Near Cascade prospect; may include prom- ising vein deposits.

knopf, 1912 (B 502), p. 50 -- Stringer lodes $12 \mathrm{ft}$ and $8 \mathrm{ft}$ wide. In Yankee Basin; little work has been done. 


$\begin{array}{ll}\text { Kensington (Mining Co.) } & \text { Gold, Lead } \\ \text { Juneau district } & \text { Juneau }(8,3,15.2) \\ \text { MF-435, 10c. } 14 & 58^{\circ} 52^{\prime} \mathrm{N}, 135^{\circ} 05^{\circ} \mathrm{W}\end{array}$

Sumary: Ore bodies are stockworks of quartz veins in fracture zones in diorlte. Kensington ore body elliptical in cross-section, $80 \times 160$ Et.i was intersected by crosscut about 1,000 ft. beLow surface. This and Eureka and Johnson ore bodies have assay limits. Principal sulfide is pyrite, galena noted at one place. Mining from 1897 to 1904; by 1901 about 12,000 tons of ore had been mined from surface and shallow workings; ore ran $\$ 3-\$ 5$ a ton. In 1904 and 1911-16 long adit was driven; undercut Eureka, Kensington, and Johnson lodes; some drifts run and stopes cut; probably some production.- several unsuccessful attempts to reopen after World war II. Includes references to: Eureka, Sherman creek. See also Johnson.

"Spencer, 1904 '(B 225I, P. 38 - Veins in Eissures in" diorite. Wright and Wright, 1905 (B 259), p. 54 -- Crosscut tunnel 1,800 ft. long completed, 1904. Cuts ledge $95 \mathrm{ft}$. wide $1,400 \mathrm{ft}$. below surface.

spencer, 1906 (B 287), p. 137 -- stockworks or fracture zones in diorite; zones of bxoken rock filled with intersecting veins of quartz carrying sulfide minerals; up to at least $100 \mathrm{ft}$. wide; one reported to have been opened at a depth of $1,400 \mathrm{ft}$. For a length of about $200 \mathrm{ft}$. Wright and Wright. 1906 (B 284), p. 32-33 - From 1897 to 1900 was opened by extenslve surface and shallow underground workings; nearly 12,000 tons of ore reported to have been mined. In 1904 crosscut intersected Eureka and Kensington ore bodies 1,300 ft. and 1,940 ft. respectively Erom portal at depth below the surface of 400 ft. and 1,000 ft, respectively; Kensington ore body has elliptical cross section $80 \mathrm{ft}$. by $160 \mathrm{ft}$. Both ore bodies have assay linits.

Wright, 1907 (B 314), p. 57 -r Was major producer bofore 1900. Did not operate in 1906.

Brooks, l911 (B 480), p. 67-68-- Reference to knopf, 1911 (B 446), p. 40-42. Knopf, 1911 (B 446), p, 40-42 m. Essentially the same data as in wright and Wright, 1906 (B 284), p. 32-33 - A little galena noted at one place; only other sulfide is pyrite. Ore runs $\$ 3-\$ 5$ a ton. No work since 1904 ; legal difflculties.

Brooks, 1912 (8 520), p. 25-26 - Development continued, 1911.

Bxooks, 1913 (B 542), p. 32 -- Deiving of adit continued. 1912,

Brooks, 1914 (B 592), P. 59 - Adit continued, Reported to have cut John son lode 4,800 ft. from portal at depth of $800 \mathrm{Et}$; some arifting on lode reported, 1913.

Brooks, 1915 (B 622), p. 41 - Development on a considerable scale, 1914. Eakin, 1915 (B 622), p. 101-102 m Kensington adit 4,700 ft. long; crosscutting and openings for stopes in progres5, 1914.

Chapln, 1916 (B 642), p. 77-78-- Kensington, Bear, and comet properties consolibated. Most work in 1915 was on Kensington [probably incluaing Johnson].

Smith, 1917 (BMB 142), p. 36 - Mi11 will probably be built, 1915. Smith, 1918 (8MB 153), p. 24 -- Explozation, 1916. planned mill was not built. 
Kensington (Mining Co.) - Continued

Eakin, 1916 (B 662), p. 77 -r Active in 1916.

p. 82-83 -- Kensington, Eureka, and Johnson lodes to be developed from Kensington crosscut only; mill to be adapted for flotation process with capacity of 500 tons per day. Ore to be mined from Kensington lode first; reserves above adit level said to exceed 500,000 tons. Dead work preparatory to mining and milling was on schedule in 1916.

Martin, 1920 (B 712), p. 30 -- Did not operate, 1918.

Budaington and Chapin, 1929 (8 800), p. 318 -- Examples of stockwork deposits.

$$
\text { p. 345-346 -- Data from Knopf, } 1911 \text { (B 446). }
$$

Smith, 1930 (B 813), P. 14-15 - Report that mine might be reopened; no production in 1928 .

Smith, 3932 (B 824), p. 16 -- Rumors that mine is to be reopened, 1929.

Smith, 1934 (B 864-A), p. 17 -- Property examination, 1933.

Smith, 1936 (B 868-A), P. 16 - Investigations, 1934 .

Smith, 1937 (B 880-A), P. 17 -- Mainly getting buildings and surface equipment in shape, 1935.

Smith, 1938 (B 897-A), p. 17 -- Road building and work on surface plant, 1936.

Smith, 1939 (B 910-Al, p. 19 -Work discontinuea, 1937.

Smith, 1942 (B 933-A), P. 17 -- Local reports that mine would be reopened under Canadian management, 1940.

Noel, 1966, p. 60 -- ore body reported to be $160 \mathrm{ft}$. long by $80 \mathrm{ft}$. wide. with a vertical range of over $800 \mathrm{ft}$.

Berg and cobb, 1967 (B 1246), p. 159-160 - Has produced ore. Only activity since world war I has been unsuccessful attempts to reopen mine. 
(Lemon Cr.)

Juneau district

MFF-435, Locs. $42,77,78$
Copper, Gold, Lead, zinc

Juneau $(14,1-14.7,6.6 \mathrm{~m} 7.25)$

$58^{\circ} 22^{\prime}-58^{\circ} 24^{\prime} \mathrm{N}, 134^{\circ} 24^{\prime}-134^{\circ} 28^{\prime} \mathrm{W}$

Summary: In early $1900^{\circ} \mathrm{s}$ was a little placer mining of gravel on glacial clay in a bedrock-dammed basin. Two narrow quartz veins in a gneissic diorite dike contain pyrrhotite, galena, sphalerite, and chalcopyrite.

Brooks, 1904 (B 225), p. 46 -w Hydraulicking, 1903,

Purington, 1905 (B 263), p. 207 -- Gold worth $\$ 14.00$ an ounce.

Spencer, 1906 (B 287), P. 218-120 - Parallel quartz veins in banded diorite dike are $8 \mathrm{in}$. to a foot thick; abundant pyrrhotite, galena. sphalerite, and chalcopyrite, Has been a little placex mining of gravel overlying glacial clay in a bedrock-dammed basin.

Wright and Wright, 1906 (B 284), P. 37 - Careful evaluation in 1905 showed that gold content of gravel is very low; placer operations ceased. Lode claims staked on quartz veins in schist near head of creek; gold values low.

Berg and Cobb, 1967 (B 2246), p. 155 -- Pyrrhotite, galena, sphalerite, and chalcopyrite in 2 narrow quartz veins in a greisslc diorite dike. 
Little Johnson

Juneau district

MF $-435,100,17$
Gold (?)

Juneau $[8.5,15.15$ I approx.

$58^{\circ} 52^{\prime} \mathrm{N}, 135^{\circ} 03^{\prime} \mathrm{W}$ approx.

Sumary: Group of claims near Jualin mine. May have been some work in late 1890 's or early 1900 's.

Wright and wright, 1906 (B 284), p、 34 an Group of claims at head of Johnson $\mathrm{Cr}$, above Jualin mine, 
Lurvey

Juneau district

$M F-435,100.82$
Gold

Juneau $(15,4,5,3)$ $58^{\circ} 1,8^{\prime} \mathrm{N}, \quad 134^{\circ} 20^{\mathrm{h}} \mathrm{W}$

Sunnary: Aurfferous gravel in filled sqald lake was mined in 1889; unsatisfactory results.

Spencer, 1906 (B 287), P, $80 \cdots$ old lake 2-1/2 acres in area was filled by gravel from Eurvey $c x$, Talus above old lake was rich enough to have been sluiced, Lake gravels were sluiced through a tunnel in 1889 with unsatisfactory results, posstbly because of poor planning. 
(Lurvey Cr.)

Juneau district

MF $-435,100.83$
Gold

Juneau (15.4, 5.25)

$58^{\circ} 17^{\prime} \mathrm{N}, 134^{\circ} 20^{\prime} \mathrm{K}$

Sumary: Gravel in ciroue basin u:idoubtedly contains gold; has not been tested.

Spencer, 1906 (B 287), p. 79-80 -- About 30,000 cubic yards of material in a cirque basin was derived from gold-bearing terrane. undoubtedly contains gold, but has not been tested. 
Marmoth (Adndralty I, )

Gold, Lead, Silver, Zinc

Admiralty district

MF-435, 100. 71

Juneau $(12,55,2,12$

$58^{\circ} 07^{\prime} \mathrm{N}, 134^{\circ} 39^{\circ} \mathrm{W}$

Summary: Schist impregnated with pyrite across a width of several hundred Tert is traversed by narrow seams of galena and sphalerite; some free gold; high gold and silver assays reported. Quartz-

filled fissures do not seem to be important. Developed by a tunnel $165 \mathrm{ft}$. long, pits, and trenches, No production: Apparently no work since about 1908 .

Wright and wright, 1905 (B 259), Q. 55-56 -- schigt country rock heavily mineralized, very few quartz-filled fissures. 3 mineralized zones 25-75 ft. wide contain galena, sphalerite, and some free gold; very high assay values in gold and silver reported. Tunnel (planned to be 1,500 It. long to undercut ore bodies) driven $575 \mathrm{ft}$. by end of 1904 .

Wright, 2906 (B 287), p. 150 - geavily mineralized schist country rock; quartz-filled Eissures of very minor importance. Schist impregnated with pyrite across a width of several hundred feet; traversed by narrow seams filled with galena and sphalerite; native gold also present. Developments consist of a 165-ft. tunnel and many pits and trenches. Results of sampling in 1905 reported to be unfavorable,

Wright and wright, 1906 (B 284), p. 40 -- Minerallzed schist traversed by occasional stringers of quartz carrying pyrite, galena, and sphalerite.

Wright, 1907 (8 314), p, 59 -- Assessment work only, 1906.

Wright, 1908 (E 345), p, 90 -r Assessment work, 1907.

Wright, 1909 i: 3791, P. 72 a- Assessment work, 1908.

Lathram and otiers, 1960 (I-323) -- Map shows symbol for occurrence of gold and lead-zinc.

Berg and Cobb, 1967 (B I246), p, 140 -- Pyxitic schist cut by narrow seans of galena, sphalerite, and a little free gold. Apparently no work since 1910.

Race and Rose, 1967 (GC 8), p. 19 -- Mineralized schist contains free gold, pyrite, galena, and sphalerite. Developed by I65-ft. tunnel, pits, and txenches. No recorded production. 
Mammoth (Douglas I.l

Juneau district
Gold (?)

Juneau' (15.4, 4.0) approx$58^{\circ} 13^{\mathrm{k}} \mathrm{N}, 134^{\circ} 22^{\mathrm{k}} \mathrm{W}$ approx.

Summary: Pyrite and quartz stringers in 2 bands of bleached schist in which crosscuts were axiven. "Country rock is greenstone and greenstóne schist with intercalated bands of slate.

Wright and wright, 1906 (B 284), p. 39-40 -. Beorock is greenstone and greenstone schist with intercalated bands of slate. Pyrite and quartz stringers in bleached schist in 2 bands that may be continuations of similar bands at Red Diamond prospect. Crosscuts were driven in mineralized schist bands.

Wright, 1907 (B 314), p. 54 - Agsessment work only, 1906. 
Mansfield Gold Mining Co. (Aaniralty I.)

Acimiralty district

MF-435, 100. 66
Copper, Lead, Zine

Juneau (14.6, 4.6) approx. $58^{\circ} 16^{\prime} \mathrm{N}, 134^{\circ} 51^{\prime} \mathrm{W}$ approx.

Sumary: Quartz veins 3-6 ft, wide in schist contain considerable chalcopyrite and pyrrhotite and some galena and sphalexite. Crosscut tunnel and surface prospecting before about 1916. No data on possible precious metal content. No record of production. Includes reference to seattle.

Wright, 1907 (B 314), p. 59 - Quartz ledges 3-6 ft. wide and 100 or more feet apart strike NW parallel to regional trend; carry considerable chalcopyrite and pyrrhotite and some galena and sphalerite. Main vein exposed by 20-ft. tunnel and surface stripping.

Wright, 1909 (B 379), p. 72 -n Crosscut tunnel being ariven, 1908; also some surface prospecting.

Eakin, 1918 (B 662), p. 85-86 -- Has been considerable prospecting in last 5 years; in mineralized schist. [Called seattle group in this reference.]

Iathram and others, 1960 (I-323) -- Map shows synbol for occurrence of copper and lead-zinc.

Berg and $\operatorname{CoBb}, 1967$ (B 1246), p. 140 or small quartz veins contain chalcopyrite, pyrrhotite, galena, and sphalerite. Exploration in early $1900^{\prime} \mathrm{s}$. No evidence that any ore was shipped. 
Maud (e) $s$.

Juneau district

MF-435, 10c. 25
Gold

Juneau $(10,8,20.75)$

$58^{\circ} 36^{\prime} \mathrm{N}, 134^{\circ} 49^{\prime} \mathrm{W}$

Summary: In 1907 an 80-ft. tunnel crosscut a 4-1/2-ft. quartz-slate stringer lode similar to that at Joyce-Jensen, which carries about $1 / 3$ oz. of gold per ton.

Wright, 1908 (B 345), p. 89 -r 80-ft. tunnel crosscut a 4-1/2-ft. vein, 1907.

Knopf, 1912 (B 502), p. 51 -- Quartz-slate stringex lode similar to that at Joyce-Jensen, which carries about $\$ 7$ a ton in gold. 
(MCGinnis Cr.)

Juneau district

MF-435, locs. 37,75
Gold

Juneau $(12.6-12.7,8.05-8.1)$

$58^{\circ} 27^{\prime} \mathrm{N}, 134^{\circ} 37^{\prime}-134^{\circ} 38^{\prime} \mathrm{W}$

Summary: Creek crosses slate belt in which are probably auriferous quartz veins. Placer gold mined fron talus cone in gulch; gold rough and mostly fine. Mining began in 1903 and ceased 1905. Assessment work (probably on lode claims), 1906-07.

Brooks, 1904 (B 225), p. 46 -- Hydraulic plant has been installed las of 1903].

Spencer, 1904 (B 225), p. 37 -- Hydraulic plant installed in 1903; not enough water to operate it.

Wright and wright, 1905 (B 259), p. 51, 54 -- Placer mining, 1904.

Spencer, 1906 (B 287), p. 123-124-- Creek rises in granite and crosses slate belt in which are probably auriferous quartz veins. Placer gold in talus apron formed by coalescing talus cones in gulches. One talus cone hydraulicked with water brought to head of cone by flume. Work in 1904-05 indicated that deposit could not be mined at a profit. Gold rough and mostly fine.

Wright and Wright, 1906 ( $B$ 284), P. 36 - About the same data as in Spencer, 1906 (8 287), P, 123-124.

Wright, 1907 (B 314), p. 56 -- Both lode and placer claims idle for most of 1906; gold values low.

Wright, 1908 (B 345), p. 88 -- Assessment work only, 1907.

Cobb, 1973 (B 1374), p. 103 -- Has been placer mining, 
Mediche Bira

Juneau district

$M F-435,10 c, 17$
Gold(?)

Juneau $(8,6,15,15)$ approx.

$58^{\circ} 52^{4} \mathrm{~N}, 135^{\circ} 03^{\mathrm{W}} \mathrm{W}$ approx.

Sumary: Group of claims near Jualin mine. May have been some work in late 1890 's or early 1900 's.

Wright and Wright, 2908 (B 284), p. 34 -- Group of claims at head of Johnson $\mathrm{Cr}$. above Jualin mine. 
Mendenhali (near Juneau)

Juneau district

MF-435, 10c. 38
Gold, Lead

Juneau $(12.95,7.6)$

$58^{\circ} 26^{\prime} \mathrm{N}, 134^{\circ} 35^{\prime} \mathrm{W}$

Summary: Quartz veinlets in interbedded slates and green chloritic schists are sparsely mineralized with pyrrhotite, arsenopyxite, and galena; arsenopyrite crystals also in slate. Arophibolite dike $100 \mathrm{ft}$. wide is cut irregularly by albite-calcite veinlets with a little pytrhotite; free gold can be panned from this rock. Development consists of open cut and 85-ft. tunnel.

Knopf, 1912 (B 502), p. 49-60 -- Stringer lode (probably $100 \mathrm{ft.} \mathrm{wide)} \mathrm{of} \mathrm{-}$ quartz velniets in interbedded black slates and green chloritic schists. Veinlets are sparsely mineralized with pyrrhotite, arsenopyrite, ana galena; slate also contains arsenopyrite crystals. Developments consist of open cut $30 \mathrm{ft}$. wide and crosscut tunnel $85 \mathrm{ft}$. long. Nearby amphlbolite dike $100 \mathrm{ft}$. wide is cut irregularly by albite-calcite veinlets with a little pyrrhotite; free gola can be panned. 
(Middle Peak)

Juneau distrlet

MF-435, loc. 58
Copper, Lead

Juneau $(16.2,4.65)$

$58^{\circ} 15^{\prime} \mathrm{N}, 134^{\circ} 15^{\prime} \mathrm{W}$

Sumary: Pyrite, chalcopyrite, and secondary copper minerals in quartz velns in volcanic rocks; galena nearby.

Lathram and others, 1959 (I-353), sample 8 - Pyrite, chalcopyrite, and secondary copper minerals in quartz veins in volcanic rocks. Galena nearby. 
Juneau district

Juneau $(11.75,9.65)$.

$M F-435,100.31$

$58^{\circ} 33^{\prime} \mathrm{N}, 134^{\circ} 43^{\prime} \mathrm{W}$

Summary: Crushed and mineralized zone 6 ft. thick trends across banding of dlorite gneiss; carries $\$ 5-\$ 12$ a ton in gold (gold at $\$ 20.67$ an ounce). Sulfides (pyrtte and galena) are rare; quartz veinlets in a few places. Ore exposed in open cuts; 2 crosscuts probably did not reach ore zone. No recorded production.

Knopf, 1911 (B 480), p. 97 -- Iunnel projected to undercut ore body begun, 1910.

Knope, 1912 (B 502), p. 53 -- Country rock is a belt of diorite gneiss in a schist terrane. Lode is a crushed and mineralized zone that trends across foliation of gneiss and contains $\$ 5$ to $\$ 12$ a ton in gold. Sulfides (pyrite and galena) are raxe; irregularly spaced quartz veinlets in a few places. Ore zone exposed by open cuts; crosscut being driven to undercut lode.

Eakin, 1915 (B 622), p. 102 -- Development reported, 1914.

Berg and Cobb, 1967 (B 1246), p. 159 -- In diorite gnedss rather than in metamorphosed bedaed rocks. Crushed gneiss containing quartz and carbonate minerals prospected by 2 tunnels and several open cuts. Lode exposed for about $\delta \mathrm{ft}$, in open cuts reported to carry $\$ 5-\$ 12$ in gold per ton. 
(Montana Basin)

Juneau district

MF -435 , Ioc. 35 cold

- Juneau $(22.35,8.4)$

$58^{\circ} 28^{\prime} \mathrm{N}, 134^{\circ} 39^{\prime} \mathrm{W}$

Sumrary: stringer lodes in schist belt and one or two thicker (up to

$2 \mathrm{ft.l}$ quartz veins contain a little gold. Discovered in 1882. Has been a few hunared leet of tunneling; not much more than assessment work.

Wright and wright, 1906 (B 284), p. 36 -- Stringex leads or lodes of mineralized slate cut by many quartz veinlets; 2 richer quartz veins were also found. Has been $400 \mathrm{ft}$. of tunneling; annual assessment work has been perfoxmed. Low values in ore bodies.

Wright, 1907 (B 314), p. 56 -- Assessment work, 1906.

Wright, 1908 (B 345), p. 88 -- Assessment work, 1907.

Knopf, 1911 (B 480), p. 109 -- First lode locations, 1882.

knopf, 1912 (B 502), p. 55 -- stringer lodes in schist belt. On one claim open cuts expose a quaxtz vein from a few inches to 2 ft. thick that cuts across foliation of schist; stained by iron oxides; no visible sulfides; flne colors of free gold.

Smith, 1937 (B 880-A), P. 17 -- Prospecting, 1935.

Berg and Cobb, 1967 (B 1246), p. 158 -- Auriferous veins discovered and staked, 1882. 
(Montana Cr.)

Juneau district

$\mathrm{MF}-435$, loc. 74
Gold

Juneau $(12.2,8.55)$ approx.

$58^{\circ} 28^{\prime} \mathrm{N}, 134^{\circ} 40^{\prime} \mathrm{W}$ approx.

Summary: Placer gold discovered in 1882; probably derived from quartz veins in slate and/or schistose greenstone. A little small-scale placer mining soon after discovery and 1928-29.

Spencer, 1904 (B 225), p. 37 --"Important" placer present.

Spencer, 1906 (B 287), p. 124-125 -- Placer gold discovered in part of creek in Montana Basin in 1882, mined on a small scale for several years. Gravel flat further downstream said to carry some gold; never. thoroughly prospected. Placer gold probably derived from quartz. veins in slate and/or schistose greenstone.

Knope, 1911 (B 480), p. 109 -- First placer mining, 1882; soon abandoned. Brooks, 1913 (B 542), p. 43 -- Report that there were investigations with view to installing a dredge, 1912.

Smith, 1930 (B 813), p. 24 -- A little placer gold mined, 1928.

Smith, 1932 (B 824), p. 28 -- A little placer gold mined, 1929.

Smith, 1942 (B 933-A), p. 32 -- New attempt at placer mining, 1940. Mainly dead work.

Cobb, 1973 (B 1374), p. 103 -- A little placer mining, late 1800's and early $1900^{\prime} s$. 
Summary: Quartz masses in greenstone conglomerate do not have pyritic mineralization; arsenopyrite and pyrite in conglomerate wall rock. No data on gold content, if any. Exploration by open cuts.

Knopf, 1912 (B 502), p. 49 -- Open cuts over a length of severai thousano feet expose masses of quartz in greenstone conglömerate near its contact with slates. Quartz not mineralized with pyrite; arsenopyrite and pyrite in altered conglomerate wall rock. 
(Mt. Young)

Juneau district

MF-435, 1005. 4, 5
Copper, Silver, Zinc(?)

Juneau $(3.85-3.9,15.1-15.55)$

$58^{\circ} 52^{\prime}-58^{\circ} 53^{\prime} \mathrm{N}, 135^{\circ} 34^{\prime}-135^{\circ} 35^{\prime} \mathrm{W}$

Sumary: Samples from veins and altered zones in a vaxiety of rocks containea traces of chalcopyrite, probably a secondary zine mineral, and anonalous amounts of silver.

Lathram and others, 1959 (I-303), sample 28 - Pyrite and chalcopyrite in cellular siliceous matrix associated with volcanic rocks.

Mackevett and others, 1971 (P 632), P. 41 - Geologlcally complex area: vaxiety of metamoxphic rocks, small granitic plutons, and mafic dikes; short quartz veins less than 6 in. thick and altered zones a few. feet thick. Samples contain traces of chalcopyrite, probably a secondary zinc mineral, and anomalous amounts of silver. 
Neison-Lott

Juneau district

$M F-435,100: 57$

\section{Gold}

Juneau $(15.95,4.85)$

$58^{\circ} 16^{*} \mathrm{~N}, 134^{\circ} 16^{\circ} \mathrm{W}$

Summary; Prospecting, including an adit driven 1,200 ft, 1915n16.

Includes references to: Alaska Gold Belt, Gold Belt. 'This

property may have been known by other names as well.

Chapin, 1916 (B 642), p. 76 -- Adit driven 1,200 ft. and work on surface installations, 1915 [called Alaska Gold Belt Co. in this reference].

Smith, 1917 (BMB 142), p. 32 -- Development, 1915.

Smith, 1917 (BMB 153), P. 18 -- Development, 1916.

Eakin, 1918 (B 662), p. 77 - A l1ttle open-cut prospecting, 1916. 
Noonday

Juneau district

ME-435, 10c. 27
Gold(?)

Juneau $(10.95,10.35)$

$58^{\circ} 35^{\prime} \mathrm{N}, 134^{\circ} 48^{\prime} \mathrm{W}$

Summary: Stringer lode $6 \mathrm{ft}$. wide of quartz and slate. Probably contains sulfides and gold, but was not developed much. See also Cascade.

Wright and Wright, 1906 (B 284), p. 34-35 - 6-ft. quartz vein in Yankee Basin. Country rock is graphitic slate and schist.

Wright, 1908 (B 345), p. 89 -- Near Cascades may include promising vein deposits.

Knopf, 1912 (B 502), p. 50 -- stringer lode 6 ft. wide. In Yankee Basin; not much work has been done. 
Northern Bell (Gold Mining Co.) Gold

Juneau district Juneau $(8.45,15.2)$

MF-435, 10C. 15

$58^{\circ} 52^{\prime} \mathrm{N}, 135^{\circ} 04^{\prime} \mathrm{W}$

Sumury: Ore body similar to that at Comet mine; fissure vein between dlorite and chlorite schist. Mine operated 1896-97; producea nearly 23,000 tons of ore. No data on tenor.

Wright and Wright, 1906 (B 284), p. 32 -- Fissure vein(s) along contact between diorite and chlorite schist. Gold native and associated with sulfides. Mine was operated in 1896-97; produced nearly 23,000 tons of ore, 788 of gold was in bullion. Ore body similar to that at Comet mine.

Berg and Cobb, 1967 (8 1246), p. 160 -- has been a productive mine. 
(Nugget Cr.)

Juneau district $M-435,10 c .76$
Gold

Juneau $(14.0,7.6)$

$58^{\circ} 26^{\prime} \mathrm{N}, 134^{\circ} 29^{\prime} \mathrm{W}$

Summary: Small gold nuggets found in shallow gravels. Assessment work was the principal activity.

Spencer, 1906 (B 287), P. 120-121 - Small nuggets of gold found in shallow gravels; nothing minable, though there was annul assessment work for several years.

Bxooks, 1912 (B 520), P. 36 -- Exeparations for instalilng hydraulic plant, 1911. 
Oleson

Juneau district

MF-435, loc. 30
Gold(?)

Juneau $(11.2,9.75)$

$58^{\circ} 33^{\prime} \mathrm{N}, 134^{\circ} 46^{\prime} \mathrm{W}$

Sumary: Quaxtz veins in slate along contact with volcanic rock pieces of slate in which are arsenopyrite crystals. No data on gold content, if any.

Knopf, 1912 (B 502), p. 51-52 -- Narrow belt of slate between 2 belts of volcanic (mainly breccia) rocks. Narrow quartz veins in slate along contact with volcanic rocks contain arsenopyrite crystals, commonly. in rock fragments enclosed in quartz. 
Opnir

Juneau district

$M F-435$, loc .14
Go1a

Juneau $(8.3,15.2)$

$58^{\circ} 52^{\prime} \mathrm{N}, 135^{\circ} 05^{\circ} \mathrm{W}$

Sumary: Quartz flssure vein 2-6 tt. thick in dioxite; many vugs and cavities lined with laxge quartz crystals. Gold values not high. Several hundred feet of tunnels and drifts.

Wright and Wright, 1906 (B 284), p. 33 -- Quartz veins; has been prospecting only; reported not to carxy high gold values.

Knopf, 1911 (B 446), p. 39 -- Quartz flssure vein 2-6 ft. thick in diorite; many rugs and cavitles lined with large glassy quaxtz crystals. A very little pytite in vein. [No mention of gold content.] Several hundred feet of tunnels and drifts.

Buddington and Chapin, 1929 (B 800), p. 317 -- Example of fissure vein. 
Penn-Alaska Mining Co,!

Gold C? I

Juneau district.

Juneau $016,85,3.851$

ME-435, 200, 59

$58^{\prime \prime} 12^{\mathrm{N}} \mathrm{N}, 134^{\circ} 10^{\prime} \mathrm{W}$

Summary: Quartz clains neax Taku Inlet; some work in 1914, Gold probably (but not certainly) present,

Eakin, 1915 (B 622), p: 102 -- Quartz clajns being developed, near Taku Inlet. Sone stripping, 2914.

Chapin, 1916 (B 642), D. 76 rr Patented claims on Taku Inlet. 
Perseverance (Mining Co.)

Juneau district

MF-435, 10c . 50
Copper, Gold, Lead, Silver, Zinc

Juneau $(15.35,5.4)$

$58^{\circ} 18^{\prime} \mathrm{N}, 134^{\circ} 20^{\prime} \mathrm{W}$

Sumary: South of and adjoining Alaska-Juneau in same lode system. Lowgrade proposityon with gold, pyrrhotite, chalcopyrite, galena, and sphalerite in quartz veins and veinlets in black slate. Mining with a Eew interruptions from 1895 to 1921. Very largescale operations, including 10,500-ft.-long Sheep creek adit and large mill (150,000-200,000 tons of ore a month mined in 1919), begun in 1915 and continued until 1921 (company lost money, 1918-21) when mine closed because of low grade of ort. Gold production 1907-21 was about 500,900 fine oz., plus an unknown amount of gold 1895-1907 and some silver, lead, and zinc. Purchased by Alaska-Juneau in 1933. Became an integral paxt of AlaskamJunesu in 1935. Includes references to: Alaska Gastineau (Mining Co.), Alaska Mining \& Power Co., Alaska Perseverance (Mining Co.). See also Alaska-Juneau.

Spencer, 1904 (B 225), p. 35 -- In mineralized zone about $800 \mathrm{ft}$, wide in black slate.

Spencer, 1906 (B 287), P. 58-59 -- Arrastre built in 2886 and 10-starop mill in 1889. Production before 1894 was about $\$ 70,000$ In gold and silr ver. Development before 1903 consigted of about 1,900 ft. of tunnels and shafts. In 1903 crosscut being driven to intersect lode at depth. p. 74-76 -- In belt of black slates cut by diorite dikes, Ore in stringer leads mainly of quartz, but with some calcite. Metallic minerals are pyrrhotite, pyrite, galena, sphalexite, and free gold; some tourmaline in gangue. Was a little mining of a hill placer on property. Long tunnel (Alexander crosscut) encountered ore.

Wright and wright, 1906 (B 284), p, 37-38 - Alexander tunnel extended to length of $2,500 \mathrm{ft}$. Vertical raise $842 \mathrm{ft}$. long connects tunnel to surface workings.

Wright, 1904 (B 314), p. 55 -- 100-stamp mill being installed, 1906. Also development of an ore body 60-80 ft. wide consisting of mineralized black slate cut by many quartz veins carrying pyrrhotite, chalcopyrite, galena, and sphalerite; more than $1,000 \mathrm{ft}$. of drifts and raise in ore body.

Wright, 1908 (B 345), p. 87-88-- Considerable mining and milling, 1907. Wright, 1909 (B 379), p. 70 - Mining, 1908.

Knopf, 1910 (B 442), p. 135 - Mining, 1909.

Knopf, 1911 (B 480), p. 96 -m Mining, 2930; 110 men employed; 100-stanp mill operated.

Erooks, 1912 (B 520), g. 25 -- Mining, 1911.

Brooks, 1913 (B 542), p. 32 -- Mining, 1912. 2,500 ft. of Sheep Creek adit driven. Mill and crushing plant destroyed by fire in December.

Rrooks, 1914 (B 592), P. 58-59 -- Sheep Creek adit connected to deepened No. 1 shaft of old workings, Apri1 1914. Sheep Creek adit is $8 x 10 \mathrm{ft}$. and $10,500 \mathrm{ft}$, long.

Brooks, 1915 (B 622), p. 41 - Considerable development, 1914. 
Perseverance (Mining Co.) -- Continued

Eakin, 1915 (B 622), p. 96 - Important development work, 1914.

p. 98-100 -- Mine about ready for large-scale operation by fall of 1914.

Chapin, 1916 (8 642), p. 75 -- Mill completed; estimated 1,200,000 tons of ore milled, ore lower grade than had been expected. Company employs 1,300 men, 1915.

p. 98 -- Lead produced from galena concentrates.

Smith, 1917 (BMB 142), p. 31-32 -- Mainly data on mining and milling methods.

Smith, 1917 (BMB 153), p. 17-18 - Same data on mining and milling methods.

Eakin, 1918 (8 662), p. 80-- Operations at zate of 6,000 tons ver day; average tenor below that expected; requires selective stoping.

Martin, 1919 (B 692), p. 29 -- Mining, 1917.

Martin, 1920 (B 712), P. 29 - Mining on a reduced scale, 1918; labor shortage.

Mertie, 1921 (B 714), P. 306 -- Mined 150,000-200,000 tons of ore a month, 1919.

Brooks, 1922 (B 722), P. 36 -- Mining, 1920.

Brooks, 1923 (B 739), P. 21 -- Plant dismantled and mine abandoned July 1, 1921; ore "too low grade to mine at a profit;" material mined in 1921 averaged 80 cents a ton in total metals.

Erooks and Capps, 1924 (B 755), P. 8 -- Plant completed in 1916; closed in 1921.

Smith, 1937 (B 880-A), p. 15 -n Mine and surface installations being developed and repaired by Alaska-Juneau Gold Mining Co., 1935.

Smith, 1938 (8 897-A), p. 15 -- Connected to Alaska-Juneau workings and mined through them, 1936.

Twentofel, 1952 (OF 60), p. 17-19 -- Historical data. Mine began milling ore in 1895, with few intermutions mined until 1921; company operated at a profit, 1915-17; lost money, 1918-21. Purchased by Alaska-Juneau Gold Mining Co., 1933; became an integral part of Alaska-Juneau.

p. 26 -- Gold production, 1907-21, was worth $\$ 10,353,843$ [about 500,900 fine oz.J. Also produced an unknown amount of gold 1895-1907 and some silver, lead, and zinc.

Herreid, 1962, P. 50 -... Iarge fold is a mass of small folds in the hinge and quite planar on the flanks.

Berg and Cobb, 1967 ( $\left.\mathrm{B}^{-} \overline{1} 246\right), \overline{\mathrm{p}} \cdot \overline{1} \overline{4}^{-}$- Was à productive mine. 
Summary: Tabular masses of quartz, some with stringers extending into the slate country rock, contain arsenopyrite and free gold; several hundred tons of probably typical ore was said to average about $0.3 \mathrm{oz}$. gold a ton. Deposit located in 1897 and intermittently mined on a small scale until 1922. Amount of production not known: in some years it was no more than enough to defray expenses. Includes references to: Prairie (near Eagle R.), (Peterson Cr.), coordinates above are for prairie claim.

Wright and Wright, 1905 (B 259), p, 54 -- operated early part of 1904. Spencer, 1906 (B 287), P. 126 -- Auriferous quartz stringer vein continuous for at least several hundred feet; appears to be in slate; greenstone and altered gabbro nearby. Arsenopyrite (on dump) apparently is the only sulfide present. Some ore from shallow workings has been treated in an arrastre. Some of surficial material has been sluiced every year.

Wright and wright, 1906 (B 284), p. 36 - Ore body (on Prairie claim) is a wide, flat-lying body of quartz in black slate. Arsenopyrite is only sulfide. No systematic work has been done.

Wright, 1907 (B 314), p. 56 -- Small-scale work on claims. Reported that enough gold is recovered with a small testing mill to defray mining expenses.

Wright, 1908 (B 345), p. 88 -- Small-scale mining, 1907.

Knopf, 1910 (B 442), p. 138 -- work, mainly trail construction, 1909.

Knopf, 1911 (B 480), p. 97 -- Considerable development work, 1910.

Knopf, 1912 (B 502), p: 53-54 -- Located in 1897; small-scale development until 1910 when larger-scale exploration was begun with the start of a crosscut tunnel and the acquisition of a diamond drill. country rock is slate with greenstone dikes and volcanic rocks; at least one lamprophyre. Masses of quartz, some tabular with stringers extending into slate, contain arsenopyrite and free gold. Several hundred tons of ore on dumps said to average $\$ 6$ [about 0.3 oz. gold] per ton.

Brooks, 1913 (B 542), p. 32 - Inclined shaft sunk $50 \mathrm{Et}$ and some open cuts, 1912.

Brooks, 1914 (B 592), p. 59 -- Some development work reported, 1913.

Eakin, 1915 (B 622), p. 102 -- Assessment work, 1914.

Chapin, 1916 (B 642), p. 77 -- 2 adits ariven and some gold probably prom duced. Quartz veins contain gold, pyrite, and arsenopyrite,

Martin, 1920 (B 712), p. 29-30 - Mining, 1918.

Mertie, 1921 (B 714), P. 109 -- small-scale mining, 1919, Recent mining has been from open cut; 2 quartz veins, one $4 \mathrm{ft}$. and the other $6 \mathrm{ft}$. thick, weatherea, disintegrated, and iron stained. 80 of gold free milling.

Brooks, 1922 (B 722), P. 36 -- Small-scale mining, 1920.

Brooks, 1923 (B 739), P. 21 -- Small-scale mining, 1921.

Brooks and Capps, 1924 (B 755), P. 24 -- Mine closed during 1922. 
Peterson - Continued

Barker, 1957' (GQ 100) -- Data from Knope, 1912 (B 502).

Berg and Cobb, 1967 (B 1246), D. IS9 - Large masses of quartz containing arsenopyrite and free gold said to average a little more than a third of an ounce $a$ ton. Claims staked about 1897; worked on a small scale intermittently until at least 1922. 
Portage

Admiralty aistrict

MF-436, loc. 65
Copper, Gold, Lead

Juneau $(10.55,5.05)$ approx. $59^{\circ} 17^{\prime} \mathrm{N}, 134^{\circ} 51^{\prime} \mathrm{W}$ approx.

Sumary: Lenticular quartz masses in slate carxy considerable chalcopyrite and pyrite and small amounts of galena. Assays indicated that ore Ls low grade in gold. Exploration was by a small shaft and open cuts. Tunnel driven to undercut lode did not reach $i t$. Mineralized rock like that at Mammoth (Admiralty I.) exposed nearby over width of $30 \mathrm{ft}$. No work reported after 1908. See also Mammoth (ABmiralty I.).

Wright, 1906 (B 287), p. 148, 150 - Vein composed of lenticular guarta masses in slate carries consiaerable pyrite and chalcopyrite and small amounts of galona, assays said to indicate that ore is low grade (for gold]; exposed by a small shaft and open cuts. Nearby mineralized schist similar to that at Young bay (Mamoth (Admiralty I.)] is exposed for a width of $30 \mathrm{ft.;}$ strikes $\mathrm{N} 10^{\circ} \mathrm{W}$, dips $65^{\circ} \mathrm{NE}$; footwall is greenstone; decrease in minerallzation defines hanging wall.

Wright and Wright, 1906 (8 284), p. 40 - Assessment work, 1905. Other data same as in wright, 1906 (B 287), p. 150.

Wright, 1907 (B 314), p. 59 -- Deposit is mineralized band of chlorite-mica schigt cut by quartz-calcite veinlets and containing small masses of copper and iron sulfides across a width of roout $40 \mathrm{ft}$. Ore exposed by open cut; apparently of low grade. Tunnel to undercut ore had not reached it in 1906.

Wright, 1909 (B 379), p. 72 -- Assessment work, 1908.

Eakin, 1918. (B 662), p. 85-86 a quotation From Wright, 1906 (B 287), p. 150. Mainly assessment work since 1904 .

Barker, 1957 (GQ-100) - Reference to Wright, 1906 (B 287), p. 150.

Lathram and others, 1960 (I-323) -- Map shows symbol for occurrence of gold, copper, and lead-zinc.

Berg and Cobb, 1967 (B 1246), p. I40 -- Irregular quartz vein carries considerable pyrite and chalcopyrite and small amounts of galena. Assays said to have been too low to encourage much development.

Race and Rose, 1967 (GC 8), p. 19 -- Pyxite, galens, and chalcopyrite in quartz masses and mineralized schist, slate, schist, and greenstone country rock. Small shaft and open cuts. No reported production. 
Puzzlex

Juneau district

ME- $435,100.28$
Gold (?)

Juneal (11.05, 10.25)

$58^{\circ} 35^{\prime} \mathrm{N}, 134^{\circ} 47^{\prime} \mathrm{W}$

Sumary: Stringer lode of quartz and slate $14 \mathrm{ft}$. wide in Yankee Basin. Probably contains sulfides and gold, but was not developed much. see also Cascade.

Wright and wright, 1906 (B 284), p. 34-35 -- "...a 14-foot lode of quartz carrying mineral...," in graphitic slate and schist.

Wright, 1908 (B 345), P. 89 -- Near Cascade; may include promising vein deposits.

Knopf, 1912 (B 502), p. 50 -- Stringer lode $14 \mathrm{ft}$. wide in Yankee Basin; not much work has been done. 
Reagan

Juneau district

MF-435, 10c. 56
Copper, Gold, Lead, Silver, Zinc

Juneau $(15.8,4.95)$

$58^{\circ} 16^{\prime} \mathrm{N}, 134^{\circ} 17^{\prime} \mathrm{W}$

Summary: Several hundrea feet of workings on a guartz vein in black slate before 1903. Sulfides reported are galena, sphajerite, chalcopyrite, pyrite, and tetrahedrite, Electrum (Au-Ag alloy) in seams and fractures. Includes reference to Regan.

Spencer, 1904 (B 225), p. 36 - The 4 veins of silver queen mine traced to Regan group of claims.

Spencex, 1906 (B 287), p, 56 - - Several hundred feet of underground work- ings. Vein in black slate; in places gouge along walls. Sulfides include galena, sphalerite, chalcopyrite, pyrite, and tetrahedrite. Electrum in seams and fractures. Some ore on dump, but no commercial shipments as of 1903.

Wright and Wright, 1906 (B 284), p. 38 -- No production or mine improvements, 1905.

Buddington and Chapin, 1929 (B 800), p. 327 -- Electrum reported. 
Red Diamond

Juneau district
Gold

Juneau $(15.4,4.0)$ approx. $58^{\circ} 13^{\prime} \mathrm{N}, 134^{\circ} 21^{\prime} \mathrm{w}$ approx.

Sumary: Band of alterea schist no more than $36 \mathrm{ft}$. wide between narrow gouge zones contains disseminated pyrite and quartz stringers explored by tunnel at least $120 \mathrm{ft}$. long. Parallel similar zone is wider and lower grade. No work since 1906. Wording in one reference implies that some gold is present.

Wright and Wright, 1906 (B 284), p. 39-40 -- Band of altered schist no more than $36 \mathrm{ft}$. wide bounded by narrow gouge seams contains disseminated pyrite and quartz stringers explored by a tunnel $120 \mathrm{ft}$. long. A parallel similar, but wider and lower grade, zone is a few hundred feet to the east. Investigations of gold content in 1905 encouraged further development.

Wright, 1907 (B 314), p. 54 -- Operations discontinued early in 1906. 
Juneau district

Juneau $(10.95,10.35)$

$M F-435,10 c .27$

$58^{\circ} 35^{\prime} \mathrm{N}, 134^{\circ} 48^{\prime} \mathrm{W}$

Summary: Small irregular calcite-quaxtz veln with auriferous arsenopyrite reported to have yielded $\$ 3,0 n 0$ (wbout 145 fine oz.) in gold in 1903.

Spencer, 1906 (B 287), p. 131-132 -- Snall, irregular vein in greenstone is calcite with a little quartz; carries considerable auriferous arsenopyrite. Deposit mined in 1903: production reported to have been $\$ 3,000$ [about 145 fine oz.] in gold.

Wright and Wright, 1906 (B 284), p. 35 -- No work, 1904-05.

Berg and Cobb, 1967 (B 1246), p. 159 -- Only productive property in Yankee Basin; small, relatively rich quartz vein reported to have yielded $\$ 3,000$ in gold in 1903 . 
st. Louis

Juneau aistrlct

MF-435, Joc. 32
Gold, Lead

Jureau $(12.0,9.35)$

$58^{\circ} 32^{\prime} \mathrm{N}, 134^{\circ} 41^{\prime} \mathrm{W}$

Sumary: Mineralized shear zone in quartz diorite gneiss contains arsenopyrite and rare pyrite and galena; reported to average about $1 / 4$ oz. gela per ton. No record of production.

Knopf, 1912 (B 50z) , p. 52 - Shear zone about $7 \mathrm{ft}$ - wide in quartz diorite gneiss consists of a breccia of quartz fragments in a matrix of altered diorite; wall rock altered for about 6 in. on each side of ore zone, which is up to $4 \mathrm{ft}$. chlck and is exposed along strike for bbout $40 \mathrm{ft}$. Arsenopyrite and rare pyrdte and galena are the sulfides present. Ore is reported to average $\$ 5$ [about 1/4 or.] of gold per ton. Bedrock well exposed, ice receded recently.

Berg and Cobb, 1967 (B 1246), p. 159 - One of few prospects in diorite gneiss rather than metamorphosed badded rocks. Metalliferous shear zone reported to average about a quarter of an ounce of gold per ton. 
(Salmon Cr.)

Juneau district
Golä(?)

Juneau (14:2, 5.95) approx. $58^{\circ} 20^{\prime} \mathrm{N}, 134^{\circ} 28^{\prime} \mathrm{W}$ approx.

Sumary: Signs of old placer workings. No data on presence of gold,

Spencer, 1906 (B 287), p. 116 -- Abandoned placer workings in lower part of stream course. No data on gold content (if any) of gravel. Doubtful that there was remunerative mining. 
(Sandy Cove)

Juneau district

MF-435, 10C. 9
Copper, FM, Gold, RE, Silver

Juneau $(0.3,12.65)$

$58^{\circ} 43^{\prime} \mathrm{N}, 135^{\circ} 58^{\prime} \mathrm{W}$

Sumbary: Quartz veins $1-12$ in. thick and altexed zones as much as $10 \mathrm{ft}$. thick in monzonite or quartz monzonite that intruded and metamorphosed limestone. Veins contain pyrite, chalcopyrite, bornite, secondary iron and copper minerals, gold, and silver. Chalcopyrite also in altered zones in monzonite and in one contactmetamorphosed zone. Developed by tunnel $110 \mathrm{ft}$. long, Samples contained as much as $0.96 \mathrm{oz}$. gold and $2.4 \mathrm{oz}$. siliver a ton. Test shipment of 4 tons of selected material returned $0.37 \mathrm{oz}$. gold and $0.15 \mathrm{oz}$. silver a ton. Samples from altered zones. near Sandy Cove (quite possibly in Mt. Fairweather quad.) contained $0.001-0.003$ percent $\mathrm{U}_{3}{ }^{\circ}{ }_{8}$. Allanite is an accessory mineral in the igneous rock.

Reed, 1938, p. 65-68 -- Small monzonite body intruded thick-bedded limestone (now largely maxble); pyrite in quartz veins (mainly in monzonite; a few in marble) and in contact-metamorphosed limestone. A few blebs. of chalcopyrite in one contact-metamorphic zone. Developed by a tunnel about $100 \mathrm{ft}$. long. Test shipments of 4 tons of selected material returned $0.37 \mathrm{oz}$. gold and $0.15 \mathrm{oz}$. silver a ton. Assayed samples contained from a trace to $0.66 \mathrm{oz}$. gold and from a trace to 2.4 oz. silver a ton.

Rossman, 1963 (B 1121-K), p. K52 -- Some altered zones near Sandy Cove [quite possibly in Mt. Fairweather quad.] contain between 0.001 and $0.00380_{3} 0^{\circ}$

Mackevett and others, 1971 ( $P$ 632), $p, 3-4--$ Gold in narrow nonpersistent quartz veins and contiguous wall rock, Reference to keed, 1938, p. 65-68.

p. 64-66 -- Quartz veins 1-12 in. thick and altered zones as much as $10 \mathrm{ft}$. thick in monzonite or quartz monzonite (containing accessory allanite). Veins contain pyrite, chalcopyrite, and bornite and secondary iron and copper minerals; gold erratically distributed. Minor gold and sulfides in altered zones. Samples contained as much as $0.96 \mathrm{oz}$. per ton (33 ppm) Aus and $1.46 \mathrm{oz}$. per ton (50 ppm) Ag. Data from Reed, 1938, p. 65-68 and Rossman, 1963 (B 1121-K), p. X52, Tunnel $110 \mathrm{ft}$. long.

Eakins, 1975 (GR 44), p. 12 - Reference to preliminary version of Mackevett and others, 1971 (R 632). 
Seward

Gold (?)

Juneau district

Juneau $(8,3,15,2)$ approx.

$M F-435,10 \mathrm{c} .14$

$58^{\circ} 52^{\prime} \mathrm{N}, 135^{\circ} 05^{\prime} \mathrm{W}$ approx.

Sumary; Quartz veins reported not to carry high gold values.

Wright and Wright, 1906 (B 284), p. 33 -- Near kensington, Quartz veins that have been prospected are reported not to carry high gold values. 
Sumary: Several quartz veins in a zone about $400 \mathrm{ft}$. wixle in black slate are near but slightly divergent in attitude from a footwall of greenstone. Veins axe as rouch as $12 \mathrm{ft}$. thick, lentlcular, and overlapping. Metallic minerals in veins include pyrite, argentlferous galena, sphalerite, chalcopyrite, pyrrhotite, arsenopyrite, argentiferous tetrahedrite, pyrargyrite, native silver, and radiating crystals of stibnite in calcite. Ore averaged about $\$ 40$ a ton (prices as of about 1895) with greater values in silver than gold. About 7,500 ft. of underground workings and stopes. Production was about $\$ 465,000$ in silver and gold (1903 prices). Claims located in 1887-88, last report of mining was in 1903. Coordinates are for main workings. Includes refexences to Ascension, Glacier, roex, ọueen.

Becker, 1898, p. 62-63 -- Minerals present at Silver queen and Glaciex include chlorite, copper pyrite, raispickel, pyrchotite, sericite, pyrargyrite, and zincblende.

p. 73-75 -- Country rack is mainly carbonaceous slate cut by a greenstone (altered gabbro?) dike; also micaceous schist. Silver queen vein consists of intercalated quartz and slate as much as $5 \mathrm{ft}$. wide. About $800 \mathrm{ft}$. Of drifts. Production through $1895 \mathrm{re}$ ported to have been, $\$ 100,000$ in silvex and $\$ 20,000$ in gold. Glacter workings on 3 veins (one of which is silver queen vein) averaging about $31 / 2 \mathrm{ft}$. In width; veins reported to be lenticular. Ore averages about $\$ 40$ a ton, with more values in silver than in gold; total production probably worth $\$ 30,000$ to $\$ 40,000$; about $1,500 \mathrm{ft}$. of workings. Metallic minerals in veins include pyrite, argentiferous galena, sphalerite, chalcopyrite, pyrrhotite, arsenopyrite, argentiferous tetrahedrite, pyrargyrite, and native silver.

Spencer, 1904 (B 225), p. 29 30 -- Production, 1903.

p. 35-36 -- On continuation of lodes in Gold $\mathrm{cr}$. basin; production through 1903 about $\$ 500,000$ [equivalent to about 24,000 fine oz. of gold]. Spencer, 1906 (B 287), p. 4 -- Mining, 1903.

p. 36-37 -- Stibnite in quartz. Pyrargyrite present.

p. 50-55 -- Several veins in black slace in a zone about $400 \mathrm{ft}$. wide are near and slightly divergent in attitude from a greenstone footwall. Veins are as much as $12 \mathrm{ft}$. thick; feathex out into stxinger leads in places. Principal veins are lenticular and overlap. Workings consist of about 7,500 ft. of drifts, crosscuts, and raises and ore stopes. Production by end of 1903 was about $\$ 465.000$ lequivalent of about 22,500 fine oz. of goldl. Claims were located in 1887-88; first mill installed 1889. 
Silver queen (Mining Co.) (continued)

Brooks, 1911 (B 480), p. 61 -- Data from Spencer, 1906 (B 287).

Brooks, 1913 (B 542), P. 32 -- Sheep Creek tunnel of Perseverance to be used to develop silver queen and neighboring properties; plan reported In 1912 .

Brooks, 1916 (B 649), p. 52 -- Reference to Spencer, 1906 (B 287), p. 36. Buddington and Chapin, 1929 (B 800), p. 327 -- Pyrargyrite reported.

p. 331 -- Radiating crystals of stibnite in calcite reported. Berg and Cobb, 1967 (B 1246), p. 154 -- Has been production. 
Summary: 2 tumnels (aggregate length $500 \mathrm{ft.)}$ ariven on a guartz vein and chlorite schist carrying auriferous arsenopyrite in black, schistose graywacke. Ore was roasted and treated in an arrastre. Amourt of gold recovered probably was small. Deposit locatid in 1893; probably no more than assessment work after 1898. See also (Windfall co.)

Spencer, 1906 (B 287), p. 129 -- Several openings on veins, at least one. of which is discontinuous and in greenstone. Several tons of ore with visible gold on a dump.

Wright and Wright, 1906 (B 284), p. 36 -- Located in 1893; small developm ments annually until 1905; assessment work only after 1898. Tunnel driven $125 \mathrm{ft}$, to undercut surface showings, results not satisfactory. Lodes are both quartz and mineralized chlorite schists in slate-greenstone country rock. Rich ore occurs, but is not uniformly distributed.

Wright, 1907 (B 314), p. 56 -- Clajus on low-grade belts of mineralized schist and greenstone traversed by quartz veinlets in which gold is irregularly distributed.

Knopf, 1912 (B 502), p. 55 - 2 tunnels (aggregate length 500 ft.) were driven on "a body of highly arsenical quartz". Ore was roasted and treated in an arrastre.

Barker, 1957 (GQ-100) -- Arsenopyrite-bearing quartz in black, schistose graywacke.

Berg and Cobb, 1967 (B 1246), p. $159--2$ tunnels exploited a quartz vein carrylng appreciable auriferous arsenopyxite that was roasted and treated in an arrastre. Amount of gold recoverd probably small. 
Summary: Quartz vein 6-8 in. thick and $30 \mathrm{ft}$. long on surface is transverse to layering in quartz diorite gneiss. Carries considerable arsenopyrite and visible free gold. Shaft sunk $30 \mathrm{ft}$. on vein. No production.

Knopf, 1912 (B 502), p. 52 -- Arsenopyrite and free gold in quartz vein 6-8 in. wide and $30 \mathrm{ft}$. long on surface transverse to structure in quartz diorite gneiss. Wall rock not altered. Shaft sunk $30 \mathrm{ft}$.

Berg and Cobb, 1967 (B 1246), p. 159 -- one of few prospects in quartz diorite gneiss rather than in metarorphosed sedimentary rocks. Quartz vein transverse to layering in gneiss carries considerable arsenopyrite and visible free gold. 
Tacoma

Juneau district $\operatorname{cold}(?)$

Juneau (10.0, 12.5) approx.

$58^{\circ} 43^{\prime} \mathrm{N}, 134^{\circ} 54^{\prime} \mathrm{W}$. approx.

Sumary: Quartz veins in black slate contain pyrite. No mention of gold content, if any.

Chapin, 1916 (B 642), p. 78 -- Openings made on quartz iissure veins in black slate of Berners $F$. Much pyrite. 
Treadwell Mines

Juneau distrıct

ME-435, Iocs. $62-63$
Copper, Gold, Lead, Molybdenum, Silver, Tungsten, zine

Juneau (15.0-15.2,4.6-4.75)

$58^{\circ} 15^{\prime}-58^{\circ} 16^{\prime} \mathrm{N}, 134^{\circ} 21^{\prime}-134^{\circ} 22^{\prime} \mathrm{W}$

Sumuary: Ore deposits consisted of gold- and sulfide-bearing quaxtz and quartz-calcite veins in shattered albite diorite sill in sequence of slate below a greenstone hanging wall: slate horses in veins also mineralized. Metallic minerals in ore include Exee gold, pyrite, pyrrhotite, magnetite, molybdenite, chalcopyrite, galena, sphalerite, tetrahedrite, native arsenic, realgar, orpiment, and (from heavy-mineral concentrate from tailings) scheelite. Mineralized zone was at least 3,500 Et. long and extended beneath Gastineau Channel. 4 mines, all under the same management and connected underground, mined the deposit; working more than 2,000 ft- deep; glory holes in early stages of mining. Deposits aiscovered in 1881; : a littl placer mining at first; lode mining began in 1882 and continued until 1922; 3 of mines caved and were flooded in 1917. Total lode production, 1882-1922, was $\$ 67,523,948.19$ from $28,777,266$ tons of ore milled (average value $\$ 2.3464$ ton). Breakdown of production into gold, silver, and lead not available. Property sold to Alaskatuneau Gold Mining Co. in 1928. Includes references to: Alaska Mexican (Gold Mining Co.), Alaska Treadwell (Gold Mining Co.) Alaska Onited (Gold Mining Co:), Mexican, Ready Bullion, Seven Hundyed Foot, Treadwell.

Beckex, 1898, p. 10 -- Placers in area discovered in 1881, lodes soon after. p. 12 -- Production Erom Treadwell, 1882-96, was $57,081,161$ and from Mexican, 1894-96, $\$ 676,161$ [total of about 375,294 fine oz.] in gold.

p. 62-70 -- Minerals present include biotite, calcite, copper pyrite, siderite, and sericite. Slate intruded successively by a syenite dike, a gabbro dike (now greenstone), and a basalt dike. ore deposition was later than the gabbro dike, possibly contemporaneous with the basalt dike. Ore is quartz stringers that contain much aurifexous pyrite, gold, chalcopyrite, arsenopyrite, galena, and sphalerite; in both slate and shattered syenite. As of 1896 all production was from Treadwell and Mexican mines; total production from Treadwell through 1896 was $\$ 7,028,649$ [about 340,041 fine 02.] in gold. Ore mined through May 1894 ran $\$ 3.20$ a ton.

Spencer, 1904 (B 225), p. 29-30-- Productive mining, 1903.

p. 39-40 - Ore is in brecciated syenite filled with a network of quartz and calcite veinlets and impregnated with pyrite; ore runs about $\$ 2$ a ton; greenstone on hanging wall and slate on footwall of ore zones. Metallic minerals in ore are pyxite, pyrrhotite, magnetite, molybdenite, native axsenic, realgax, orpiment, and stibnite [see Spencer, 1906 (B 287), p. 36); assays show only a little silver. 
Treadwell Mines (continued)

Spencer, 1905 (B 259), p. 69-87 - Ore is mineralized albite diorite dikes in a northwest-striking zone that dips NE beneath a hanging wall of greenstone (altered diabasic lava flows) and above black slate footwall. Ore is in quartz-calcite and calcite veins and veinlets in fractured albite diorite; metalic minexals are free gold, pyrite, pyrchotite, magnetite, molybdenite, chalcopyrite, galena, sphalexite, native arsenic, realgar, oxpiment, and stibnite [see spencer, 1906 (B 287), P. 36]. Small amounts of ore in slate in horses in diorite and along margins of alkes. Oxe mined averages about $\$ 2$ a ton.

Wright and Wright, 1905 (B 259), p. 52-53 -- Mining continued, 1904. Ore from treadwell mine averaged $\$ 2.44$ a ton; mining expense was $\$ 1.37 a^{\cdot}$ ton. Brooks, 1906 (B 284), p. 6 -- Majox lode mining operation in Alaska, 1905. Spencer, 1906 (B 287), p. 3-4 -- First work on property was placer mining; other historical data. Production to Jan. 1, 1904, was about $\$ 24,000,000$ (about 1,161,000 fine oz. in gold).

p. 36 -- Reported stibnite turned out to be rutile.

p. 90-116 - Production, L882-1905, from lodes was worth $\$ 24,758,828$; placer production, 1881-1883, was worth $\$ 60,000$. Most of data are in Spencer, 1905 (B 259), p. 69-87.

Wright and wright, 1906 (B 284), p. 39 -- Production in 1905 was worth $\$ 3,024,330$. Cost of open-pit mining (botton 600 Et. below sea level) nearly equal that of mining from larger stopes.

Wright, 1907 (B 314), P. 50-53 -- All four mines operated, 1906; depths of 1,500 ft. at Treadwell and Ready Bullion, 1,100. ft. at Mexican, and $990 \mathrm{ft}$. at 700 Foot. Production from first three was worth $\$ 3,046,035^{\prime \prime}$

Brooks, 1908 (B 345), p. $35-1,353,286$ tons of ore mined in 1906.

Wright, 1908 (B 345), p. 86-87 - Mining, 1907. 700 Foot connected to Treadwell.

Brooks, 1909 (B 379), p. 28-29-- Mining, 1908.

Brooks, 1909 (B 394), p. 194-195 -- Source of most of lodengo3d production in southeastern Alaska. Deepest workings $1,600 \mathrm{ft}$.

Wright, 1909 (B 379), p. 68-69-- 1,367,920 tons of ore mined yielded $\$ 2,999,420$.

Brooks, 1910 (B 442), p. 33-34 - Dominant lode producer In Alaska, 1909." Knopf, 1910 (B 442), p. 134-135 - Mining, 1909.

Brooks, 1911 (B 480), p. 28 -- Overshadows all other lode mining, 1910.

Brooks, 1911 (B 480), p. 60 -- Ore bodies are combination of veins and impregnated zones.

p. 67-68 -- Mines have produced more than $\$ 40,000,000$ in gold.

Rest of data from Spencer, 1906 (B 287).

p. 93 -- Molybdenite present.

Knopf, 1911 (B 480), p. 95-96 - Mining, 1910.

Brooks, 1912 (B 520, p. 25 -- Mining, 1911.

Brooks, 1913 (B 542), D. 31-32 -- Mining, 1912.

Brooks, 1914 (B 592), p. 58 -- Mining, 1913. 3 of 4 mines below 2,000 ft.

Brooks, 2915 (B 622), p. 41 -- Mining, 1914.

Eakin, 1915 (B 622), p. 96-97 - (Good summary of history of mines through 2914.1 Value of gold produced, 1882-1914, was $\$ 58,318,780$ (about 2,821,421 fine oz.l. 
Treadwel1 Mines (continued)

Chapin, 1916 (B 642), p. 74 -- Mining, 1915.

5mith, 1917 (BMB 142), p. 33-35 -.. Data on mining practice, etc.

smith, 1917 (BMB 153), p. 20-22 - Mainly data on mining and milling methods and recreational facilities for emplyees.

Eakin, 1918 (B 662), p. 77-79 - Mining, 1916. Some of mills were shut down to avoid heavy drawing of ore beneath areas showing signs of subsidence. Production through 1916 was worth $\$ 54,013,782$ labout 3,096,941 fine oz. of gold]. As early as 1913 there had been caving in upper workings accompanied by fissuring in hanging wall and moderate flow of salt water at 1,600-ft. level. Caving and subsidence on April 21, 1917 resulted in complete flooding of rreadwell, Seven Hundred Foot, and Mexican mines with sea water.

Martin, 1919 (B 692), p. 29 -- OnIy Ready Bullion operated; mine being deepened with a view to undercutting the flooded other mines at 3,000-ft. level.

Martin, 1920 (B 712), p. 29-30 -- stoping, largely to provide waste for filling worked-out portions of mine. Mining on 2,800-ft. level, 1918.

Mertie, 1921 (B 714), p. 112-113 - Resdy Bullion mine operated at about 24,000 tons a month, 1919.

Brooks, 1922 (B 722), p. 36 -- Ready Bullion mine operated, 1920.

Brooks, 1923 (B 739), p. 21 -- Ready Buliion raine opexated, 1921.

Brooks and Capps, 1924 (B 755), p. 8 - 2 of 3 large mines flooded in 1917.

p. 23-24 - Ready Bullion mine and mill were permanently closed Dec. $20,1922$.

Moffet, 1927 (B 792), p. 10 -- Some gold produced in the coarse of cleaning up the property, 1925.

Buddingon and Chapin, I929 (B 800), p. 319 -- ore bodies are dikes of albite diorite veined with metalliferous quartz and calcite and impregnated with auriferous pyrite.

p. 329 -- Molybdenite in all parts of ore bodies.

p. 331 -- Rutile, native arsenic, realgar, and orpiment present.

P. 347 - Ore consisted of fractured, mineralized albitediorite dikes.

p. 364-365 - Quotation from Spencer 1906 (B 287).

p. 377 - Deposits occur in fractured and metallized albite diorite and albite monzodiorite sheets.

p. 388 -- Reference to Spencer, 1906 (B 287).

Smith, 1930 (B 8IO), p. 12 -- Plan to selI Alaskan properties to AlaskaJuneau Gold Mining Co., 1928.

Smith, 1930 (B 813), p. 13 -- Physical properties in Alaska sold to AlaskaJuneau Gold Mlning Co., 1928.

5mith, 1937 (B 880-A), p. 15 -- Plan to sink shafts to depths below old workings and crosscut to exploxe any ore bodies that might be encountered, 1935.

Snith, 1938 (B 897-A), P. 18 - Rumors of possibie reopening (see above, Smith, 1937 (B 880-A), p. 15), 1936, were unfounded. 
Treadwell Mines (continued)

Smith, 1942 (B 926-C), p. 172-174 - References to many of above citations. Molybdenite was widespread in occurrence, but evidently was not in masses of such concentration as to have attracted attention as a resource that could be mined separately.

Bain, 1946 (1C 7379), p. 12-14 -- Total tonnage of ore milled, August 1885 to December 28, 1922, was $28,777,266$ tons, average value $\$ 2.3464$ a ton, total value $\$ 67,523,948.19$.

Twenhofel, 1952 (OF 60), p. 4-- Total production, 2882-1926, estirated at $\$ 67,500,000$.

p. 15 -- had been staked by 1881 .

p. 21-22 - All uineg except Ready Bulllon caved, April 1917. Later Alaska-Juneau Gold Mining Co. assumed Treadwoll holdings.

p. 45 - Lode system 1s minexalized portion of diorite porphyry sill in Treadwell slate.

p. 93 - Diorite porphyry sills associated with ore deposits.

West and Benson, 1955 (B 1024-B), p. 53 -- Heavy minerals in sluice-box concentrate from Ready Bullion tailings included magnetite, pyrite, ilmenite, barite, gold, ankerite, sphene, scheelite, and zircon.

Kaufinan, 1958 (IC 7844), p. 7 -- Historical data. Production was more than $\$ 67.5$ million in gold and silver during 37 years.

Noel, 1966, p. 54 - Between 1885 and 1922 produced $\$ 67,500,000$ in gold and silver from milling $28.8 \mathrm{milli}$ ion tons of ore with average value of $\$ 2.35$ a ton.

p. 60 - 4 mines on one vein structure at least 3,500 ft. long. Mineralization in fractured albite diorite dikes; fractures filled by veinlets of quartz and calcite with minor pyrite, pyrrhotite, galena, sphalerite, chalcopyrite, and arsenopyrite. Dikes cut slate, phyllite, and interbedded amphibolito.

Berg and Cobb, 1967 (B 1246), p. 154-155 -- Impregnations and networks of veins in albite diorite dikes carry gold, pyrrhotite, sphalerite, galena, pyrite, arsenopyrite, chalcopyrite, tetrahedrite, molybdenite, magnetite, and a little scheelite, native arsenic, realgar, and opiment.

U.5. Bureau of Mines, 1967 (IC 8331), p. 6-7 -- Mineralized albite-diorite dikes intruded along structure of black slate; impregnated with sulfides; in part shattered and filled with reticulating veins of calcite and quartz, which also carry sulfides. Gold evenly distributed through dikes; no well-defined or shoots.

Koschmann and Bergendah1, 1968 (P 610), p. 20-21 - Through 1905 produced $\$ 26,556,470$ in gold. Began caving in 1913. References to Eakin, 1918 (B 662); 8rooks and Capps, 1924 (B 755); Spencer, 1906 (B 287).

Thorne, 1969 (USBM of 22-69), p. 33 -- With Alaska-Juneau produced gold and silver valued at more than $\$ 148$ million from about 117 million tons of ore. 3 Treadwell mines flooded in 1917; Ready Bullion operated until 1922. Stmons and Prtnz, 1973 (P 820), p. 267 -- Example of gold-quartz lodo. 
Treasury Hill

Juneau district

ME-435, 10C. 39
Gold

Juneau $(12.25,7.45)$

$58^{\circ} 25^{\prime} \mathrm{N}, 134^{\circ} 40^{\prime} \mathrm{W}$

Sumary: Ore body. about $50 \mathrm{ft}$. wide in an altered gabbro dike in slates and greenstones. Dike cut by arsenopyrite-bearing transverse quartz veins; wall rock also contains arsenopyrite and pyrrhotite. Contains as much as $\$ 3$ (about $0.145 \mathrm{oz}$. ) gold per ton. Elsewhere on property are large quartz masses that contain coarse gold and minor amounts of arsenopyzite and pyrite. All work probably in about 1909.

Rnopf, 1911 (B 480), p. 97 -- Outcrops of quartz discovered, 1910. Knopf, 1912 (B 502), p. 55-58 -- Discovered, 1908, most exploration in 1909. Trenches and a short tunnel exposed an ore body that in places ts $50 \mathrm{ft}$. wide and is in an altered gabbroic alke cut by transverse quartz velns as much as several fett thick containing much arsenopyrite. Wall rock also contains arsenopyrite crystals and grains of pyrrhotite. Dike is in slates and greenstones; bordered on hanging wall side by green schist. Apparently baxren vein material contains as much as $\$ 3$ a ton in gold, altered dike rock averages $\$ 1.10$ a ton. Trenching elsewhere on property exposed large masses of quartz that carries coarse gold and small amounts of argenopyxite and pyrite.

Barker, 1957 (GQ-100) -- Data from Knopf, 1912 (B 502). 
Tyee

Juneau district
Gold (?)

Juneau

$\mathrm{SEl} / 4$ guad.

Sumary: Prospecting, 1916. On Dougles I. north of Treadwell.

Eakin, 1918 (B 662), P. 77 -- Diamond drilling, 1916. On Douglas I. north of Treadwell. 
Juneau district

Juneau $(14.2,5.95)$

MF-435, Ioc. 45

$58^{\circ} 20^{\prime} \mathrm{N}, 134^{\circ} 28^{\prime} \mathrm{W}$

Sunmary: At least one vein $8 \mathrm{ft}$. thick between slate and a greenstone dike contains quartz, carbonate, albite, mica, rutile, arsenopyrite, pyrite, chalcopyrite, sphalerite, galena, tetrahedrite, and chalcopyrite. No data on gold content, but there must some; 1,150 ft. of development and a small mill; statement that owners (as of about 1903) seened pleased with tasts. Last reported work was in 1914. May have been minor production, but not definitely so stated. Includes references to: Salmon. Creek, lodes at mouth of Salmon Creek.

Spencer, 1906 (B 287), p. 117 -- Vein as much as 8 ft. thick between slate footwall and greenstone (probably originally a gabbro dike) hanging wal1. Gangue minerals are quartz, calcite or dolomite, albite, and small amounts of white mica and rutile. Sulfides are mainly arsenopyrite, pyrite, and chalcopyrite; some sphalerite, galena, and tetrahedrite. Owners seem pleased with tests of ore. About 240 ft. of crosscuts and drift asd some surface stripping.

Wright and wright, 1906 (8 284), p. 37 - Nearly 100 ft. of tunneling completed and a small testing mill placed on property in 1905 . Ore contains arsenopyrite, pyrite, chalcopyrite, galena, and sphalerite.

Wright, 1907 (B 314), p. 56 -- On mineralized basic alke cut by numerous quartz veinlets. 625 ft. of underground workings.

Wright, 1908 (B 345), p. 88 -- Assessment work only. 1907.

Brooks, 1915 (B 622), p. 211 - Development, 1914, at Salmon Creek property. Eakin, 1915 (B 622), p. 96 -- Prospecting, 1914.

p. $101-4$ or 5 velns 6 to $20 \mathrm{ft}$. thick. Total of 1,150 ft. of development work has been done; $300 \mathrm{ft}$ recently. 20-ton tubular mill in operation and 35-stamp mill under construction, 1915. Work is strictly prospecting. 
(White Glactex)

Juneau district

MF $-435,100.8$
Copper, silver

Juneau $(0.7,14.35)$

$58^{\circ} 49^{\prime} N, 135^{\circ} 55^{\prime} w$

Sumary: Small altered zones in limestone carry copper minerals and minor amounts of silver.

Mackevett and others, 1971 (P 632), p. 4 -- Small altered zones in limestone and marble contain chalcopyrite.

p. 42 -- Mineralized zones cut limestone and structurally overlying volcanic rocks; some are near mafic dikes and a small granitic cupola. Altered zones in limestone less than $10 \mathrm{ft}$. thick and generally not traceable for more than $100 \mathrm{ft}$.; contain ankeritic carbonates, barite, quartz, copper minerals, pyrite, minor amounts of silver. Sample from altered zone in volcanic rocks contained $20,000 \mathrm{ppm} \mathrm{zn}$; mineral not 1dentified. p. $54--28,2 n$ in a sample. 
Summary: Veinlets in Tertiary quartz monzonite intrusive into Paleozoic volcaric and metasedimentary rocks contain pyzite, chalcopyrite, galena, sphalexite(?), thorianite, and euxenite (a rare-earth and uranium niobate and titanite). Explored by shallow pits and a diamond-dxill hole: Nearby disseminated pyrite, arsenopyrite, and chalcopyrite occur in a cherty rock. See also Alaska Endicott.

Mertie, 1921 (8 724), p. 112 -- At lower end of bay disseminated pyrite, arsenopyrite, and chalcopyrite occur in cherty rocks.

Lathran and others, 1959 (I-303), sample 15 -- Pyrite, chalcopyrite, galena, sphalexite(?), ilmenite veinlets in rare-earth-bearing quartz monzonite.

Matzko and Freeman, 1963 (B 1155), p. 44 - Traces of thorianite and partially oxidized pyrite in a metamorphosed igneous rock consisting of feldspar with streaks of white mica. Explored by several shallow pits and a dianond drill hole. Material with $0.2 \%$ eu reported.

Berg and cobb. 1967 (B 1246), p. 162 -- Quartz monzonite contains sparse veinlets of pyxite, chalcopyrite, galena, ilmenite, and traces of a thorium mineral. X-ray examination indicated trace amounts of $\mathrm{Zn}$, $\mathrm{Nb}$, and $U(?)$. Explored by several pits and a diamond-drill hole.

Eakins, 1975 (GR 44), 0. 12, 14-17 -- Claims on SE edge of a small Tertiary quartz monzonite rass that intruded Paleozolc volcanics and metasediments. References to above reports and an unpublished report of euxenite (niobate and titanite of yttrium, exbium, cerium, and uranium). 
(Windfall Creek)

Juneau district

MF-435, locs. 34, 73
Copper, Gold, Laad, Zinc

Juneau ( $11.75-12.25,8.5-8.7)$

$58^{\circ} 29^{\prime}-58^{\circ} 30^{\prime} \mathrm{N}, 134^{\circ} 40^{\prime}-134^{\circ} 43^{\prime} \mathrm{W}$

Sumary: Placer gold discovered in 1882 and mined internittently until 1906; yielded little more than wages. Quartz veins in schist near Smith \& teid prospect contain arsenopyrite, galend, pyrite, sphalerite, a little chalcopyrite, and some gold. Prospecting only. See also Snith \& Heid.

Brooks, 1904 (B 225), p. 46 -- Hydraulic plant has been installed [as of 1903]. spencer, 1904 (8 225), p. 37 -- Hydraulic plant installed, 1903; not enough water to operate.

Purington, 1905 (B 263), D. 207 -- Gold worth $\$ 17.50$ an ounce.

Wright and wright, 1905 (8 259), p. 51, 54 -- Placer mining, 1904.

Spencer, 1906 (B 287), p. 127-129 -- Placer gold discovered in early 1880's and mined sporadically to 1903. Gold in gravel of flat above a small lake was derived from one fork; gravel contains many vein-quartz fragrents, some of which contain visible sulfldes. Lode prospecting in 1903; encouraging assays of samples of some quartz veins reported.

Wright and Wright, 1906 (B 284), p. 36 -- Placer mining, 1905. Gold finegrained, dull, and hackly. Bedrock is bands of slate and greenstone.

Wright, 1907 (B 314), p. 51 -- Placer mining, 1906.

p. $56--1,000 \mathrm{cu}$. Yds, of gravel sluiced, 1906.

Wright, 1908 (B 345), p. 88 -- No placer mining, 1907. A little lode prospecting.

Knopf, 1911 (a 480), p. 109 -- Placer gold discovered, 1882. Mining yielded little more than wages.

Kropf, 1912 (B 502), p- 55 - Near Smith and Heid prospect quartz stringer lodes in schist carry arsenopyrite, galena, pyrite, sphalerite, a little chalcopyrite, and gold. Tunnel was driven $3.0 \mathrm{ft}$, on one lode. Barker, 1957 (GQ-100) -- Data from Knopf, 1912 (B 502).

Cobb, 1973 (B 1374), p. 103 -- Has been small-scale placer mining. 
Winn

Juneau distxict

$M F-435,100.41$
Gold (?)

Juneau $(12.6,6.7)$

$58^{\circ} 23^{\prime} \mathrm{N}, 134^{\circ} 38^{\prime} \mathrm{W}$

Sumury: Quartz-albite carbonate veinlets cut an altered dike which, near the veinlets, is impregnated with pyrite and arsenopyrite. Prospect was located in 1882. Exploration work consists of a 20-ft. tunnel. No data on gold content, if any, of deposit.

KnOpE, 1912 (B 502), p. 59 -- Located in 2882; explored by a tunnel $20 \mathrm{ft}$. long. Altered aike rock, probably originally albitediorite, is cut by veinlets of quartz, albite, and ferriferous carbonate. Dyrite and arsenopyrite impregnate rock near veinlets. 
Yakima (Mining Co.)

Juneau district
Gold(?), Lead, Zinc

Juneau $(14.95,4.6)$

$58^{\circ} 15^{\prime} \mathrm{N}, 134^{\circ} 43^{\prime} \mathrm{W}$

Summary: On Douglas I. No workable ore developed. Several hundred feet of underground workings exeavated during prospecting in 1903 or earlier. In altered and pyritized zone in greenstone at least $300 \mathrm{ft}$. wide and a mile long. Galena and sphalerite in material on dump. No data on possible gold content.

Spencer, 1904 (B 225), p. 41 -- Several hundred feet of prospecting with. a shaft developed no deposit of workable ore [as of 2903]. On. Douglas $I$.

Spencer, 1906 (B 287), P. 92 -- Country rock is alternating beds of slate and greenstone altered to sericite schist with considerable quartz and calcite, much disseminated pyrite in small cubes. Shaft and (from size of dump) several hundred feet of workings. Galena and sphalerite in narrow seams containing quartz and albite on dump. Belt of altered rock is at least 300 ft. wide and at least a mile long; exposed on Bullion Co. behind Ready Bullion Mine. Wright and wright, 1906 (B 284), p. 40 -- No improvements during last 2 years [as of 1905]. Property not considered very important.

Wright, 1907 (B 314), p. 54 -- had been idle for several years [as of 1906]. 
Unnamed occurrence

Juneau district

MF-435, IOC. 2
Cobalt, Copper

Juneau $(4.05,17.0)$

$58^{\circ} 58^{\prime} \mathrm{N}, 135^{\circ} 33^{\prime} \mathrm{W}$

Summaxy: Sample contained pyrrhotite, chalcopyrite, and pyrite(?) in siliceous.greenschist. cobalt, probabiy in the pyrrhotite, is a major trace constituent.

Lathram and others, 1959 (1-303), sample 16 -- Pyrrhotite, chalcopyrite, pyrite(?) in siliceous greenschist. Cobalt is a major trace constituent.

Berg and Cobb, 1967 (B 1246), P. 162 -- Chalcopyrite associated with pyrrhotite that probably contains txaces of cobalt. 
Unnamed occurrence

Juneau district

MF-435, 100, 6
Copper

Juneau $(2.95,14.7)$

$58^{\circ} 50^{\prime} \mathrm{N}, 135^{\circ} 40^{\prime} \mathrm{W}$

Sumary: Veinlets of bornite, secondary copper minerals, and epidote associated with siliceous volcanic rocks.

Lathram and others, 1959 (1-303), sample 20 - veinlets of bornite, secondary copper salts, and epidote associated with siliceous volcanic rocks.

Berg and Cobb, 1967 (B 1246), p. 162 -- Bornite.has been found. 
Unnamed occurrence

Juneau alstrict

$M \mathbb{P}-435$, 10c. 3
Copper

Junedu $(3.2,16.4)$

$58^{\circ} 56^{\prime} \mathrm{N}, 135^{\circ} 39^{\prime} \mathrm{W}$

Sumary: Massive pyrite and chalcopyrite boulder in glacial moraine.

Lathram and others, 1959 (1-303), sample 17 - Massive pyrite and chalcopyrite boulder in glacial moraine. 
Unnamed occurrence

Admiralty district MF-435, loc. 72
RE

Juneau (14.4, 1.3)

$58^{\circ} 04^{\prime} \mathrm{N}, 134^{\circ} 27^{\prime} \mathrm{W}$

Summary: Samples of heavy minerals from pegmatite veins in a terrane of granite, migmatite, and contact-metamorphic rocks contained yttrium, zirconium, niobium, thorium(?), lanthanum, cerium, pxaseodymium, and neodymium.

Lathram and others, 1959 (I-303), samples 26, 27 -- Rare-earth-bearing pegmatite. Contains $\mathrm{Y}, \mathrm{La}, \mathrm{Ce}, \mathrm{PI}, \mathrm{NQ}$ and $\mathrm{Zr}$ and $\mathrm{Nb}$.

Berg, 1960 (P 400-B), p. B38 -- X-ray spectroscopic analyses of samples. of heavy minerals fxom pegmatite veins indlcated the presence of yttrium, zirionium, niobium, thorium(?), lanthanum, cerium, praseodymium, and neodymium. Pegmatite veins are associated with granite, migmatite, and contact-metamorphic rocks, which underlie an area of 50 square miles.

Lathram and others, 1965 (B $1181-R$ ), p. R43 -- quotation from Berg, 1960 (P 400-B)

P. R45 (samples 26,27) -- Same as Lathram and others, 1959 (I-303), samples 26,27 .

Berg and Cobb, 1962 (B 1246), P. 140-141 -- Samples from pegmatite contained trace amounts of $\mathrm{Zr}$ and $\mathrm{Ce}$ and several other rare-eaxth elements.

Eakins, 1975 (Gr 44), p. 11-12 -- Reference to Lathram and others, 1965 (8 $1181-R$ ), P. R43, R45. 
Synonyms, Claim Names, Operators, ana Owners Many mines and prospects have undergone changes in both their own names and in the names of their operators and owners. All names that appear in the clted references appear in this summary either in the first section as occurrence names or in this as synonyms. Descriptions of placer deposits commonly glve little information on the location of Individual wes or claims, so the names of all operators. and owners of placer mines and claims are in this section w1th a notation to refer to the description of the stream that was mined or prospected. 
$A B$-- see Aurora Borealis

Adrairalty -- see Adgiralty-Alaska

Alaska - see Adniralty-Alaska

Aleska Chief -- see Groundhog

Alaska Consolidated -- see Perseverance

Alaska Consolidated Coldfield Co. -- see Alaska Treasure

Alaska Consolidated Mines Co. -- see Peterson

Alaska Consolidated Mining Co. -- see Alaska Treasure

Alaske Ebner -- see Ebner

Alaska Enpire Gold Mining Co. -- see Hawk Inlet Mining Co.

Alaske-Gastineau (Madng Co.) -- see Perseverance

Alaska Gold Belt (Mining) Co. -- see Nelson-Lott

Alaske Gold Mines Co. - see Perseverance

Alagka Gold Mining Co. -- see Admiralty-Alaska, Indiana

Alaska Mexican (Gold Mining Co.) -- see Treadwell Mines

Alaska Mining \& Power Co. -- see Ferseverance

Alaska Perseverance (Mining Co.) -- see Perseverance

Aleska Treadwell (Gold Mining Co.) -- See Treadwell Mines

Alaska Treasure Colsolidated Mines Co. - - see Alaska Treasure

Alaska United (Gold Mining Co.) -- see Treadwell Mines

Alaske Wllloughby Mining Co. -- see Admiralty-Alaska

Algunican Development Co. -- see Jualin

Alice Miler -- see Admiralty-Alaska

Allan -- see Fawk Inlet Mining Co.

Alma -- see Hawk Inlet Minting Co.

Alte - see Perseverance

Amalga - - see Eagle River

Amelia - see Eagle RIver

American Gold Mining Co. -- see (Gold Cr.), Stlver Queen

Armor -- see Hawk Inlet Minjag Co.

Ascension -- see Silver Queen

Bandy -- see Hawk Inlet Mining Co.

Batella - - see Hawk Inlet Mining Co.

B.C. -- see Black Chief

Beach -- see Adriralty-Aleska

Bear Valley -- see Hawk Inlet Mining Co.

Bengley -- see Hawk Inlet Mning Co.

Bennet -- see Alaska-Juneau

Berners Bay Mining \& Milling Co. -- see Bear, Comet, Kensington, Ophir, Seward

Blue Jay (Admiralty I.) -- see Admi rolty-Alaska 
Blue Leed -- see Alaska Dano

Bonanza - see Alaska Endicott

Boston -- see Hawk Inlet Mining Co.

Boston \& Alagka Co. - - see Admiralty-Alaska

Browm -- see Hawk Inlet MIatng Co.

Calffomia (Adoirelty I.) -- see Hawk Inlet Mintag Co.

California \& Nevada Copper Co. -- aee Ebner, Fallam

Cannonball - - see Peterson

Cardiff -- see Hawk Inlet Mining Co.

Carrie Nation - - see Admiralty-Alaska

Chatham -- see Alagka Dano

Cbeechako -- see Clark (Carlson Cr.)

Cleveland -- see Admiralty-Alaska

Cliff - see Hawk Inlet Mining Co.

Cobalt - - see Hawk Inlet Mining Co.

Columbia -- see Admiralty-Alaska

Creek -- see Treasury $\mathrm{Rl} 1 \mathrm{l}$

Davles \& Pond -- see Californle (near Eagle R.)

Deer Meadow -- see Hawk Inlet Mlning Co.

De Roux -- see (Bear Cr.)

Detroit-Alaska Mining Co. -- see (Windfall Cr.)

Devil Club -- see Adndralty-Alaska

Dora - - see Hallam

Dorothy -- see Fawk Inlet Mining Co.

Dublin -- see Hawk Inlet Minjag Co.

Dunkle - see Hawk Inlet Mining Co.

Eagle - - see Hawk Inlet Mining Co.

Eastera Alaske Mindng \& Milling Co. - - see Perseverance

Endicott-Alaska Mining \& Miling.Co. -- see Alaska Endicott

Endicott (Mining \& Milling Co.) -. see Alaska Eodicott

Eureka - see Kensington

Fairview -- see Hawk Inlet Marng Co.

Florence -- see Adralralty-Alaske

Frances - - see Alrska Dano

Francis -- see Alaska Dano

(Funter Bay) -- see Admiralty-Alaska (Gold Mining Co.)

Funter (Bay Minjag Co.) -- see Admiraity-Alasks

Gelveston -- see Hawk Inlet Minding Co.

George -- see Howk Inlet Mining Co.

Geyser -- see Admiralty-A.laska 


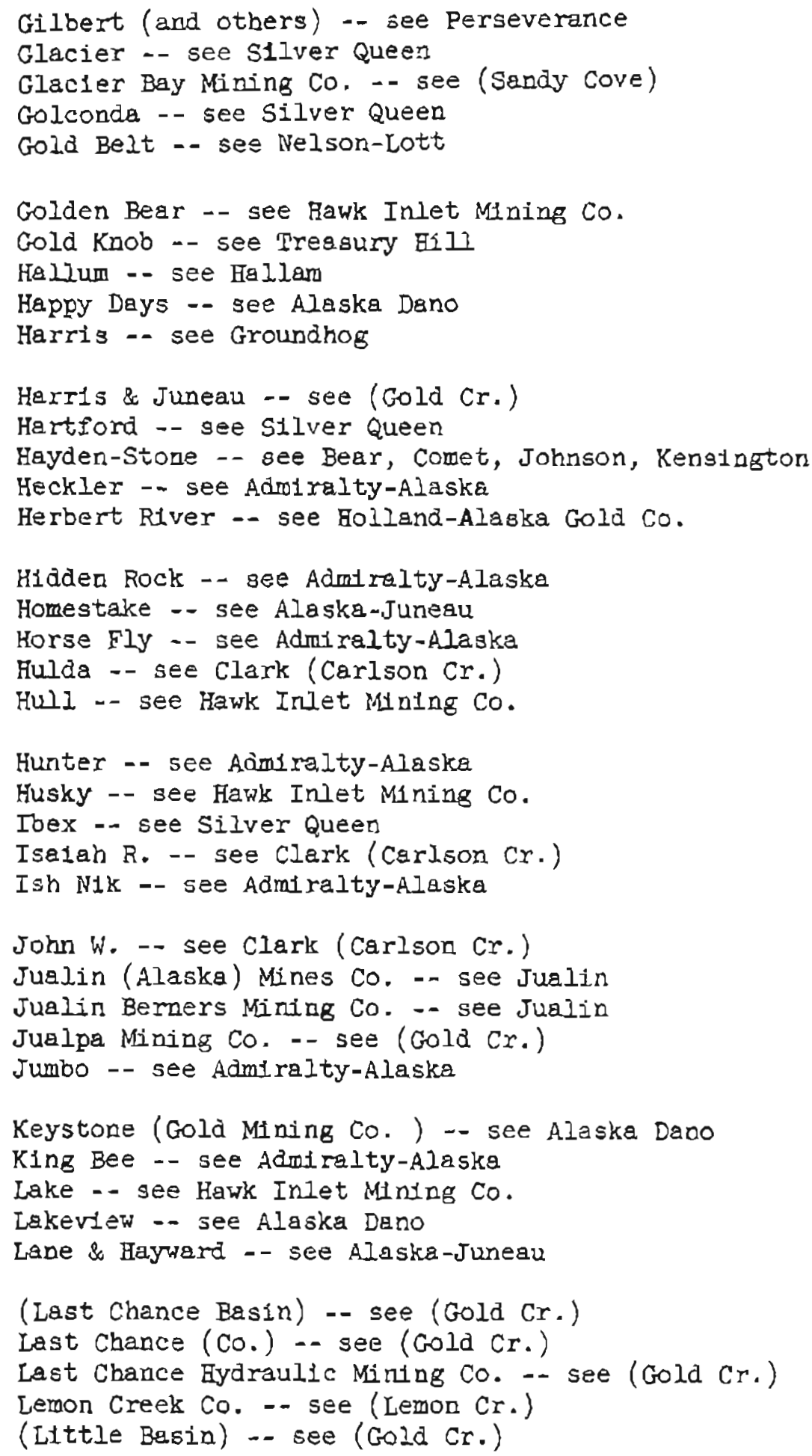




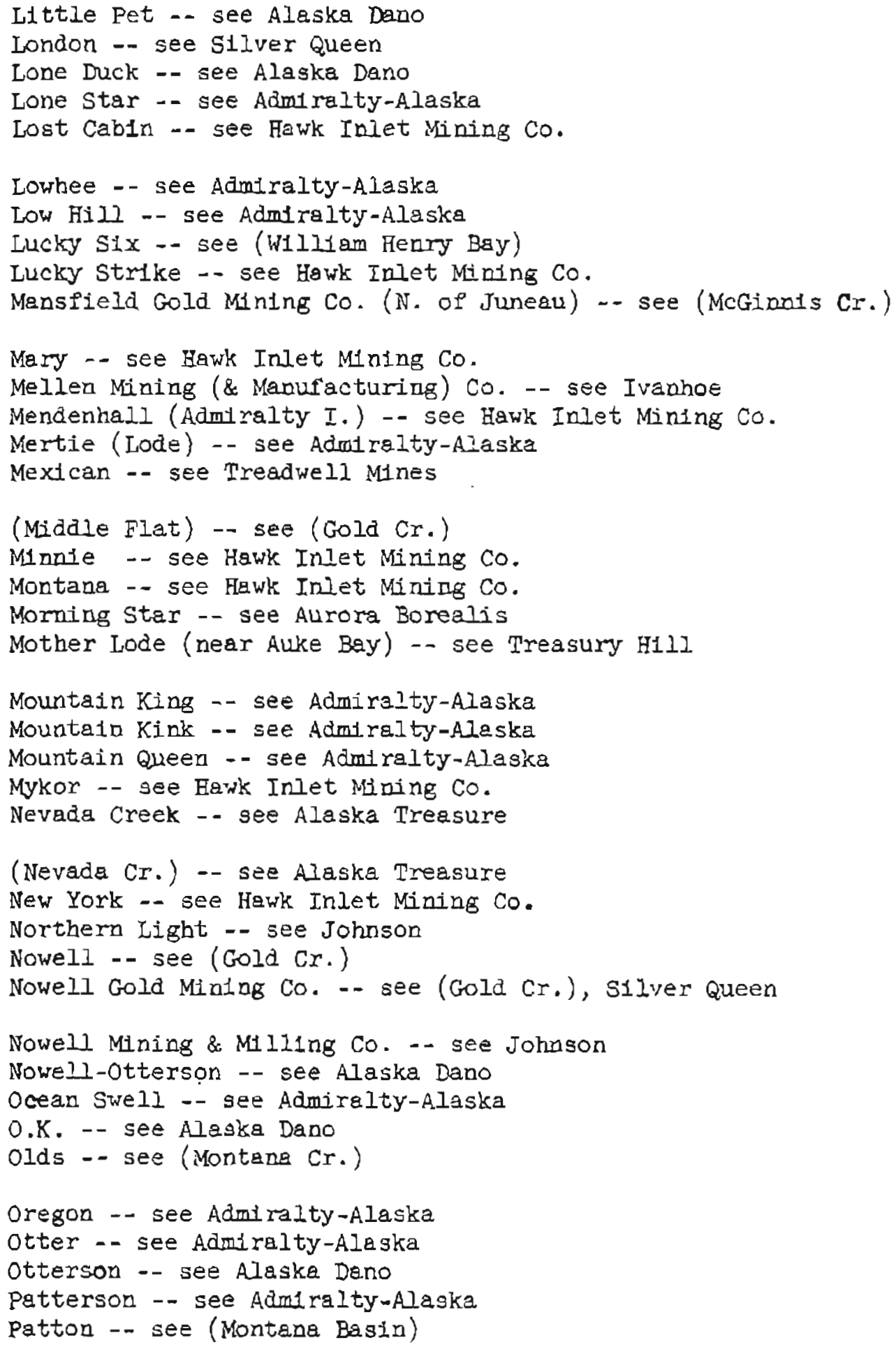


Pekov1ch -- see Admirelty-Alaske

(Peterson $\mathrm{Cr}$.) -- see Peterson

Point -- see Aonj ralty-Alaska

Portland-Alaska (Gold) Mining Co. -- see Horrible

Prairie (Admiralty I.) -- see Hawk Inlet Mining Co.

Frairle (near Eagle R.) -- see Peterson

Premier - see Hawk Ialet Mining Co.

Premier Gold Mining Co. -- see Clark (Carlson Cr.)

Pungle Down -- see Adrot ralty-Alaska

Pungle Up -- see Adiriralty-Alaska

Pyrate -- see Admiralty-Alaska

Queen -- see Silver Queen

Queen Bee -- see Admiralty-Alaska

Raisin Valley -- see Hawk Inlet Mining Co.

Ready Bullion -- see Treadwell Mines

Regan -- see Reagan

Riverside -- see Hawk Inlet Mindag Co.

Saddle Rock -- see Hawk Inlet Mining Co.

St. Clair, Metjay, Austin \& Paul - see (Sandy Cove)

Salmon Creek (Gold Mining $\mathrm{Cr}$.) -- see Wagmer

Sandstone \& Ward -- see Eagle RIver

Seattle -- see Mansfield Gold Mining Co. (Admiralty I.)

Seven Hundred Foot - - see Treadwell Mines

Sherman Creek -. see Kensington

(Silver Bow Basin) -- see (Gold Cr.)

Silver Bow Basin Mining Co. - - see (Gold Cr.)

Silver Bow Basin Hydraulic (Mnes) Co. -- see (Gold Cr.)

Sllver Cord -- see Silver Queen

Skyscraper -- see Hawk Injet Mning Co.

Speulding -- see Treasury gill

Star - - see Adoliralty-Alaska

Sumait (Admiralty I.) - see Alaske Dano

Sumut ( near Juneau) -- see Groumdhog

Sunburst - see Alaska Dano

Sunrise -- see Hawk Inlet Mining Co.

Sunget -- see Hawk Inlet Mining Co.

(Sunset Cove) -. see Clark (Carlson Cr.)

Sutherland -- gee Perseverance

Swamp Lily -- see Admiralty-Alaska

Sylvia -- see Hawk Inlet Mining Co. 
Taku (Mtaing \& Milling Co.) -- see Ebner

Tellurium (Mining \& Miling Co. ) - - see Admiralty-Alaske

Texas -- see hawk Inlet Mining Co.

Tingwella -- see Aamiralty-Alaska

Tremont -- see Groundhog

Two Shaft -- see Alaske Deno

Uncle Sam -- see Adouralty-Alaske

Uncow - - see Admiralty-Aleska

U.S. Smelting \& Reflning Co. -- see Ebner

U.S. Smelting, Refining \& Mining Co. -- see Ebner

Valley -- see Adwiralty-Alaska

Walla Walla -- see Hawk Inlet Mining Co.

War Eagle - see Admiralty-Alaska

War Horse - see Alaska Dano

Weshington - see Aduiralty-Alaska

Wasp -- see Alaska Dano

Water Witch -- see Treasury Hill

Wild Cat -- see Hawk Inlet Mining Co.

Wiley (\& Spaulding) -- see Treasury Hill

William N. -- see Clark (Carlson Cr.)

Wlliams (Mining Co.) -- see Hawk Inlet Mining Co.

W1lloughny (\& Weir) -- see Admiralty-Alaska

Winona -- see Alaska Dano

Yakamew Mining Co. -- see Yakima

Yankee Boy -- see Joyco-Jensen

Yankee Girl -- see Joyce-Jensen

Yellow Hornet -- see Clark (Carlson Cr.) 


\section{References Cited}

References are listed in standard bibllographic format alphabetically by author and, secondarily, chronologically if an author prepared more than one report or map. This section was prepared by stacking bibllography cards in a document protector and duplicating them on an offlce copying machine. This procedure maked retyping unnecessary, but hes the disadvantages thet the edges of cards may reproduce es horlzontel lines between entrles and thet margins and spacing are not constant. 
Bein, i. F., 2946, Alaska's minerals as a basis for industry: U.S. Bur. Mines Iaf. Circ. 7379,89 p.

Barirez, Fred, 1957, Geology of the Juneau (B-3) quadrargle, Alaske: U.S. Geol. Survey Geol. Quad. Mep GQ-100, I sheet, scale I:63, 360.

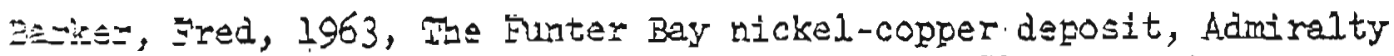
Esiland, Aleskan: U.S. Geol. Survey Bull. 1155, p. 1-10.

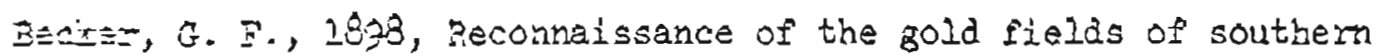
Lleske, witi soue notes on general geology: U.S. Geol. Survey

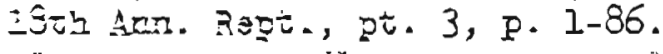

sen: $\vec{i}$. C., 1300, Throe areas of possible mineral resource potentiel in soltheestern Alaska, in Geologlcal Survey research I0́́: U.S. Gool. Survey Prof. Paper 400-B, p. B38-B39.

Bez, F. C., 2nd cobb, E. H., 1967, Hetall1ferous lode deposits of 1.issieg: i.5. Gol, Survey Bull. 1246,254 P.

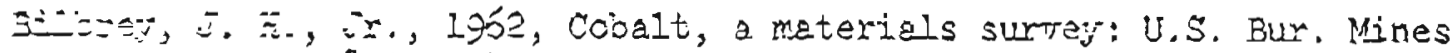
-

S=ä, J. A., exi $\widetilde{s}=-$, A. B., 1969, Minor element content of stream-sediment

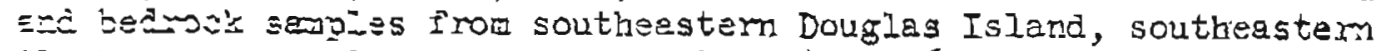
insska: U.S. Geol. Survey open-file report $361,2 \mathrm{p}$.

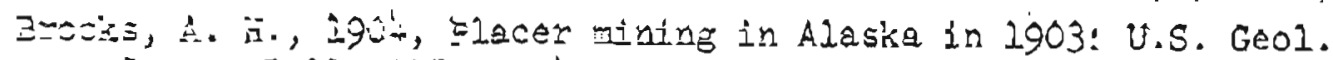
Sumey Sul2. 225, p. 43-50.

Ercoks, A. F., 1905, placer miniñ in Haske in 1904: U.S. Geol. Slirvey Bu11. 259, p. 18-31.

Brooks, A. H., 1906, The mining incustry in 1905: U.S. Geol. Survey 기․ $234,0.4-9$.

Brooks, A. "̈., 1908, The mining intlustuy in 1907: U.S. Geol. Survey Buㄱ. $345,0.30-53$.

Brooks, A. K., 1909, The mining industry in 1908: U.S. Geol. Survey Bul1. 379, p. 21-62.

Srcoles, A. F., 1909, Mineral resources of Alaska, in U.S. Geological Survey, Papers on the conservation of mineral resources (reprinted fren report of the Fational Conservation Comission, February, 1909): U.S. Geol. Survey Bul1. 394, p. 172-207.

Brooks, A. H., 1910, The mining industry in 1909: U.S. Geol. Survey Bul1. 442, p. 20-46. 
Juneau

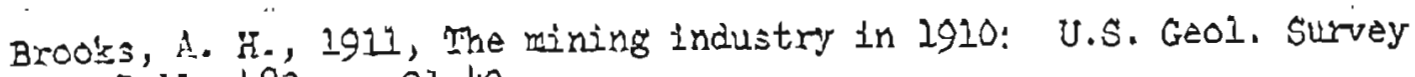
Bi17. 480, ?. 21-42.

Brocis, A. B., 1911, Goologic features of Alaskan metalliferous lodes: i.s. Geol. Survey surl. 480, p. 43-93.

Buacis, A. B., 19:2, The minting industry in 1911: U.S. Geol. Survey $5=11$. $520,0.1 T-44$.

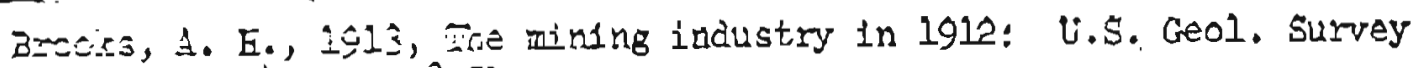
2017. $542,2.13-51$.

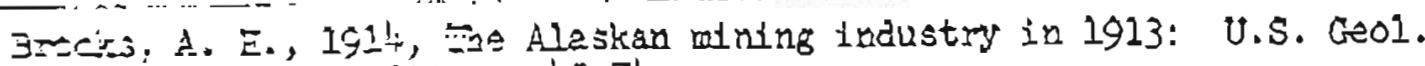

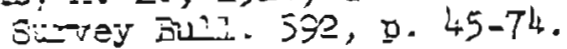

B=s_s, A. E., 191j, The Alasian winding industry in 1914: U.S. Geol.

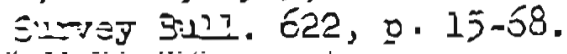

Ẽracks, A. H., 1910́, Antimory depostis of Aleska! U.S. Geol. Survey $\Xi 17.6 \div 9,57 \mathrm{~g}$.

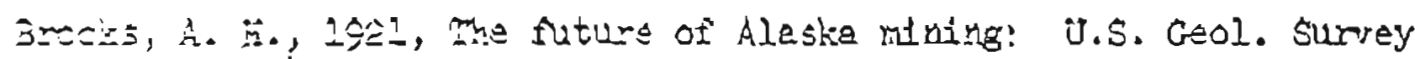

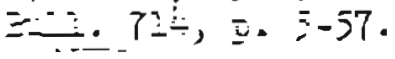

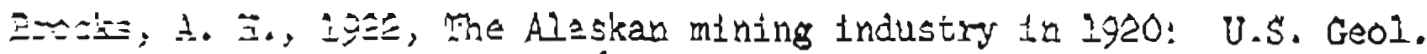

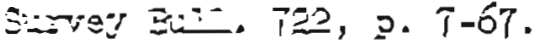

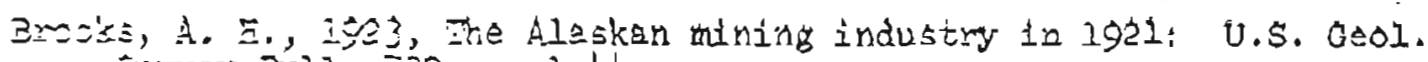

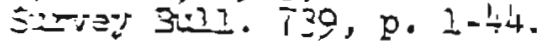

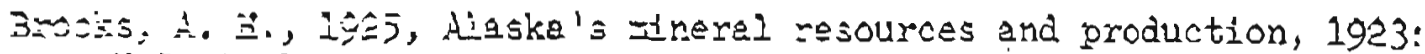
i.s. Ceoi. Sirvey Bull. 773, p. 3-52.

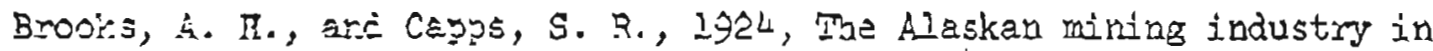
1922: U.S. Geol. Survey Burl. 755, p. 3-49.

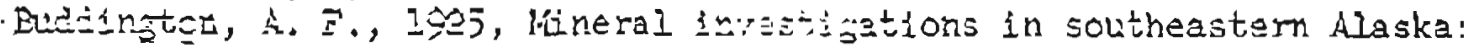
U.S. Geol. Sarvey Bull. 773, p.,71-139.

3udington, A. E., 1叉25, Mneral 1:restigations in southeastern Alaska: 1.S. Cool. Survey Bull. 783, c. 41-62.

Sudington, A. F., and Chapty, theocore, 1929, Geology and mineral deposits of southeastera Alaska:-U.S.: G@ol. Survey Bull. 800, 398 .p.

Chapln, Theodore, 1916, Mining derelognents in southeastern Alaska:

U.S. Geol. Suzvey sull. óla, p. 73-104. 
Juneau

Coto, E. H., 1972, Metaliic rineral resolures map of the Juneau quadrangle, Alssixa? U.S. Geol. Survey Msc. Field Studies Map dis $-435,1$ sheet, scale $1: 250,000$.

Coso, Z. H., 1973, Plaker deposits of Alaska! U.S. Geol. Surrey Bull. $1374,213 \mathrm{p}$.

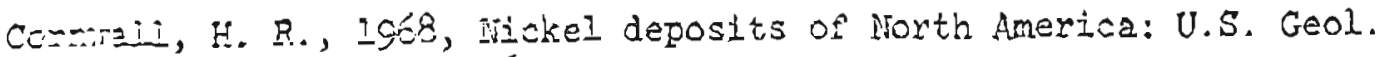
Evrvey Buiz. 1223, $62 \mathrm{p}$.

Cow sis., United Etsies mineraI resources! U.S. Geol. Survey Prof.

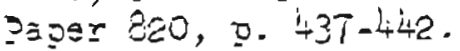

Eeviz, э. U., 1915, Mining in the Junequ reglon: U.S. Geol. Survey Bull. $6 \geq 2,0.95-102$.

tetr:- … M., 1918, Iode wiring in the Juneau gold belt: U.S. Geol. s-iniey Bull. 662, p. 77-92.

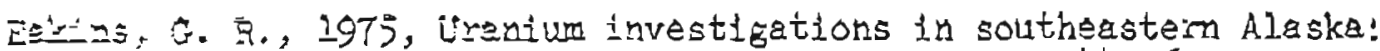
izasia Diт. Geol. Gaophys. Surveys Geol. Rept. 44, 62 p.

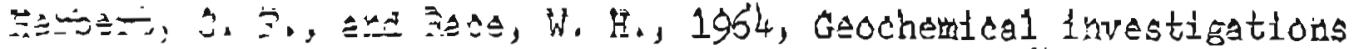
c: seientis aress in soutbeastern Alaska, 1964! Alaska Div.

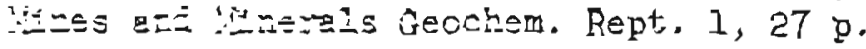

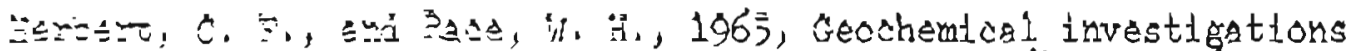
Q: selostec ereas in southeastern Aiaska, 1964 and 1965 !

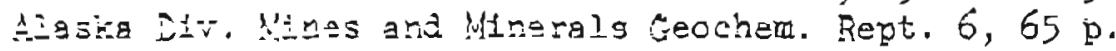

jewreid, Gonion, lyos, Prelimingry rexort on geologic mapping in the Coast Ragge mineral belt, in Ilaske Division of Mines and Minerals, Psport. For the year 136?: Jkneau, Alaska, p. 44-59, 62-67; elso pub. as Geologie Rept. 1, 1962.

tolt, S. P., and Moss, J. H. 1946, Exploration of a nickel-coppercooalt deposit at Funter Bay, Adiniralty Island, Alaska: U.S.

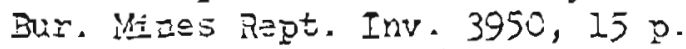

Kaurmen, Alrtn, 1958; Southegstem ilaska's mineral industry: U.S. Bur. fines Inf. Cire. 7844, $37 \mathrm{p}$.

Knopi, Adoici, 1910, Mining in southeastem Alaska: U.S. Geol. Survey Buli. 442, פ. 133-143.

Knopi, Adolph, 1911, Geology ô the Bemers Bay region, Alaska: U.S. Geol. Survey Bull. 446, 58 p. 
Juneau

Knopr, Ajoloh, 1911, 将ing in southeastern Alaska: U.S. Geol. Survey Bull. $480,0.9-102$.

Knozf, Adolph, 19l2, ti:e Eagle River region: U.S. Geol. Survey Bull. -30, p. $103-111$.

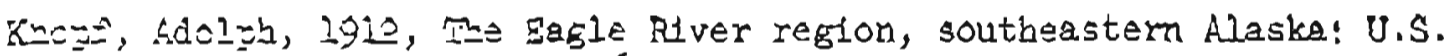
seol. Surtey 3uill. $502,61 \mathrm{p}$.

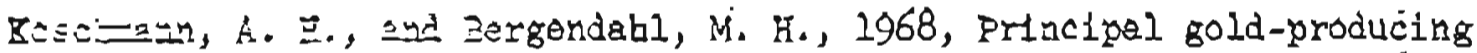
Itstrleis or the inited states: U.S. Geol. Survey Prof. Paper 610, $\Xi \Xi \vdots$.

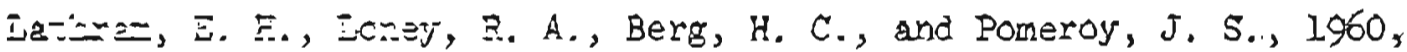
Exogness zap o the geology of Adniralty Island, Aleska: U.S. joci. Sirry i:isc. Geol. Inv. Map I-323, l sheet, scale 1:250,000.

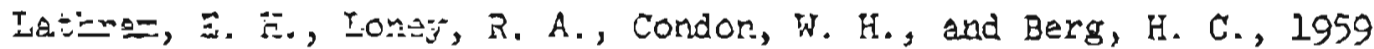
Jag $\because$ ․ Eeol. Sumrey Wisc. Seol. Inv. Map I-303, I sheet, scale I: $: 2 j 3,000$.

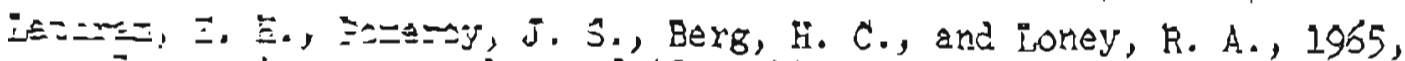

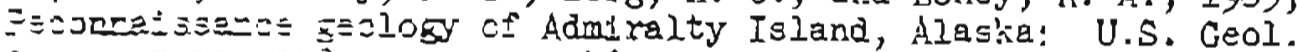

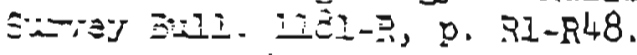

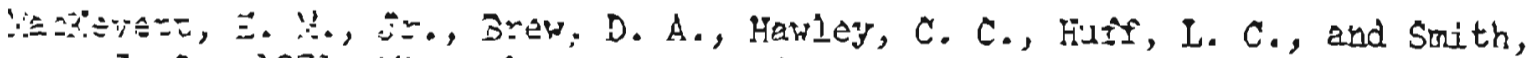

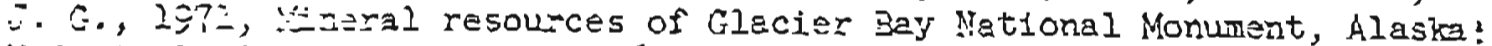

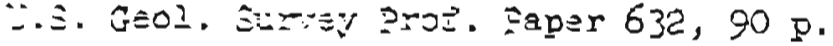

Kertix, G. C., 19i9, the Aleskan minizg industry in 1917: U.S. Geol. Surrey Bill. óg2, p. 11-42.

Wartin, G. C., 1920, The hiaken minting igdustry in 1918: U.S. Geol. Survey 3uld. 712, p. 11-j2.

Maizis, J. J., shd rieeman, V. L., 195́3, Sumary of reconnalssanes for urentu in Alaska, 1955! U.S. Gäol. Survey Bull. 1155, p. $33-49$.

Mertie, J. B., Jr., 1921, Lode mintng in the Junaau end Ketchikan districts: U.S. Geol. Surrey Bull. 714, 0. $105-128$.

Moffit, F. H., 1927, Minerel industry of Alaska in 1925: U.S. Geol. Survey Bull. 792, p. 1-39.

Noel, G. A., 1966, The productive mineral deposits of southeastern Alaska, in Alaska Division of Mines and Minerals, Reporc for the year 1966: Juneau, Alaska, p. 51-57, 60-68. 
Juneer

Puriuston, C. T., 1905, Methods and costs of gravel and placer mining In Alaska: U.S. Geol. Survey Bull. 263, 273 p.

Yase, H. E., and Rose, A. W., 2967, Geochemical and geological investigations : ACmiralty Island, Alaska: Alaska Div. Mines and Minerals Geochem.

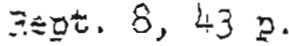

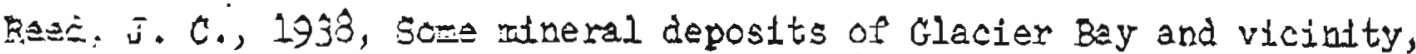
Aisska: Eccu. Geolosy, v. 33, p. 52-80.

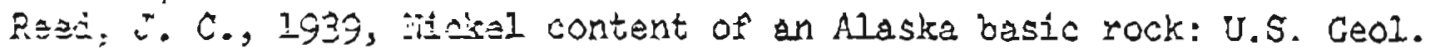

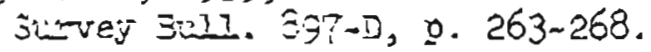

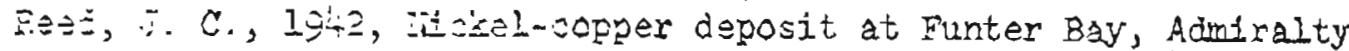
Isiani, Alasia: U.S. Ceol. Survey Bull. 936-0, D. 349-361.

Rosscen, D. I., 1963, Geology of the eqstem part of the Mount Feirratuhar quadren-ile, Glacier Bay, Alaska: U.S. Geol. Surrey Bull. ii2l-K, D. $x-K 57$.

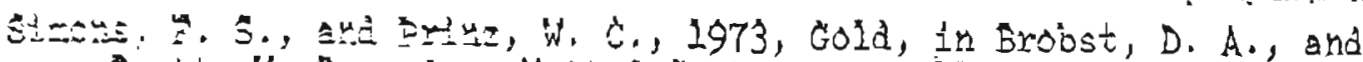

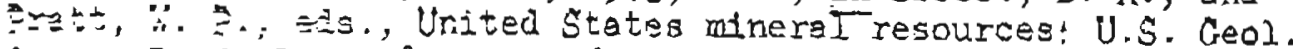
Surs:

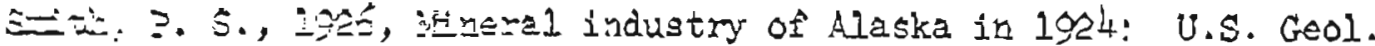

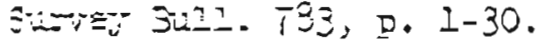

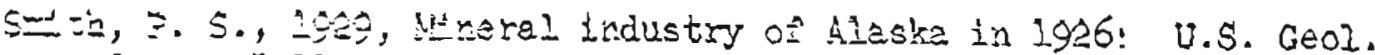
Suryay biel. 797, D. 1-50.

Smits, D. S., 1930, Wuergl industry of Alaska in 1927: U.S. Geol. Sursey biri. 810, p. $1-64$.

Satí, P. S., i9is, Mneral industry of Aleska in 1928. U.S. Geol.

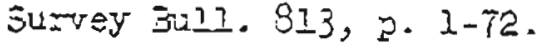

Satic, P. S., 1932, Hitneral industiry ô Alaska in 1929: U.S. Geol. Surves 3a17. 824, p. 1-81.

Salth, 2. S., 1933, Mineral indust=J of Alaska in 1930: U.S. Geol. Surrey Bull. 836, p. $1-83$.

Suith, P. S., 1933, Mineral indust of Alaska in 1931: U.S. Geol. Survey Bul1. 844-A, 2. 1-82.

Smith, P. S., 193', Mineral Industry of Alaska in 1932: U.S. Geol. Survey Bu21?. 857-A, p. 1-91. 
Juneeu

Sattin, F. S., 1934, Wheral industry ò Alaska in 1933: U.S. Geol. Survey Bull. 86́-A, D. 1-94.

Sal-b, P. S., 1936, Wherel industry of Alaske in 1934: U.S. Ceol. Enz-rey Bull. 868-A, p. 1-91.

S-izi. ?. S., 1937, yeseral industry of Alaska in 1935: U.S. Geol. Sumiey 3u11. S80-A, p. 1-95.

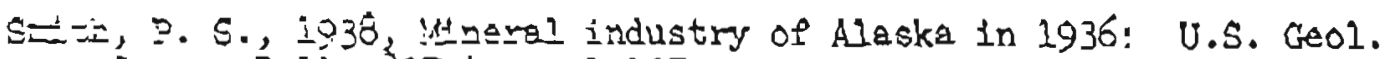
si-rey Euti. 007-A, p. I-107.

Sw: ?. S., 1939, itneral industry of Aleska in 1937: U.S. Geol.

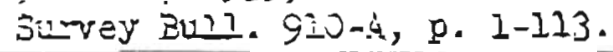

Sidit, ‥5., 1939, Mineral Injustry of Alaska it 1938! U.S. Geol. somrey 5u1l. 917-A, o. 1-113.

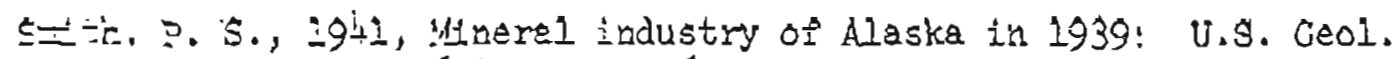
Eim:zy Bi1, 925-A, p. 1-106.

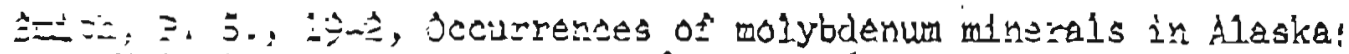

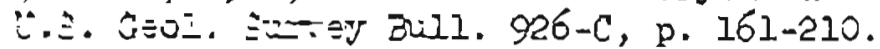

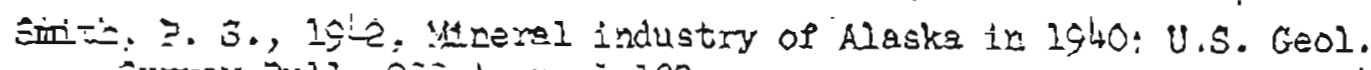

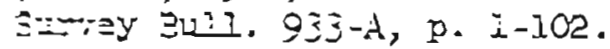

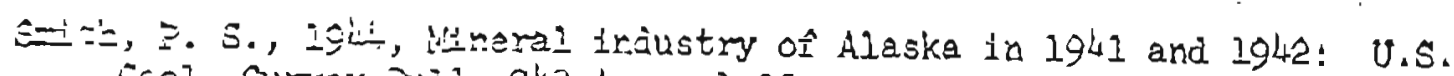
FEsI. Suriey 3uil. 943-A, p. 1-23.

S-tin, S. S., 1917, The mining intustry in the Terrltory of Alaska durtag the ceisniar year 1915! U.S. Sur. Uines Bull. I42, 66 p.

Sutih, S. S., 19i7, The mining lueustzy in the Territory of Alaska during the calendar yeer 1916: U.S. Bir. Lines Bull. 153, 89 p.

spercez, A. C., 1904, The Juneau gold belt, Alaska: U.S: Geol. Survey Bull. 225,2 . 28-42.

Spencer, A.C., 1905, the Treaciwell ore deposits, Dourtas Island: U.S. Geol. Survey Bill. 259, ․ 69-87.

Spencer, A. C., 1906, The Juneau gold belt, Alaska: U.S. Geol. Survey Bul1. 28T, p. I-137.

Thome, R. I., 1969, Silver in Alaska, in U.S. Bureau of ilines, Silver in tha United States - potential resources: U.S. Bur. Mines openfile rept. $22-69$, p. $32-36$ 


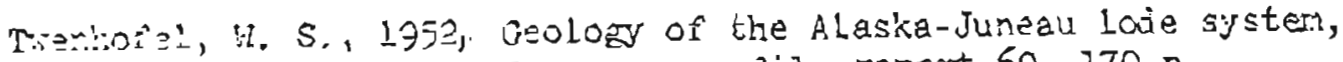
Llaska: U.S. Geol. Surrey open-rile report 60, $170 \mathrm{p}$.

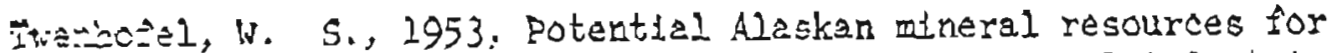
zoppos $\gtrsim 2$ electrociem cal and electrometallurglcal industries in the uper ryan ianal area, Alaska! U.S. Geol. Survay Ji=e. $252,14 \mathrm{p}$

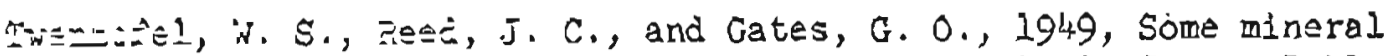
Erestigetions in southerstem Alaska: U.S. Ceol. Survey Bull.

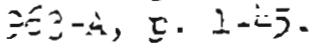

i.s. Eursali os yinas, 2:67, Production potential of known gold deposits

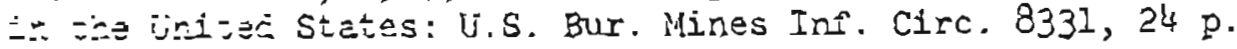

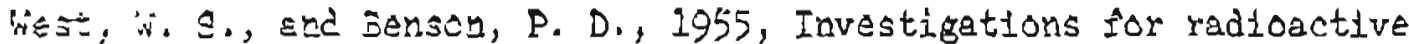
Eayostis in soutieestera Alaska: U.S. Creol. Survey Bull. 1024-B, 2. $25-57$.

Hirtej: 0. $\because ., 1006$, A recounaissance of Admirelty Island: U.S. Geol. Sג-

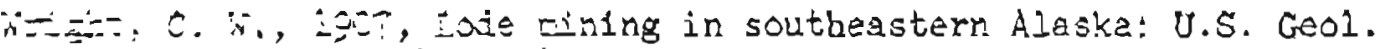

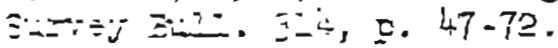

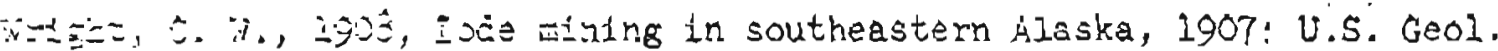

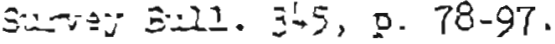

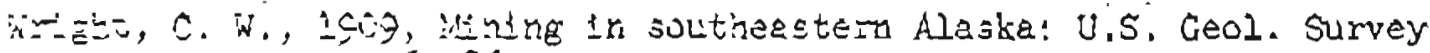

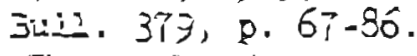

Wright, s. Z., exd itright, C. W., 2905, Economic âevelopments in southenster f.laska: U.S. Geol. Survey Bull. 259, p. 47-68.

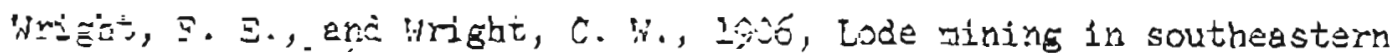
Allosta: U.S. Geol. Surtey Bill. 254, p. 30-54. 